\title{
BUSINESS MODEL INNOVATION - A CONCEPT BETWEEN ORGANIZATIONAL RENEWAL AND INDUSTRY TRANSFORMATION
}

Edited by

Jörg Freiling

Volume 11 Issue 1

2015 


\section{Contents}

Jörg Freiling 3

Editorial: Business Model Innovation-A Concept Between Organizational

Renewal and Industry Transformation

Karla Straker, Cara Wrigley

The Role of Emotion in Product, Service and Business Model Design

Aki Harima, Sivaram Vemuri

Diaspora Business Model Innovation

Christiana Müller, Stefan Vorbach

Enabling Business Model Change: Evidence from High-Technology Firms

Franziska Günzel-Jensen, Anna B. Holm

Freemium Business Models as the Foundation for Growing an E-business Venture: A Multiple Case Study of Industry Leaders

Päivi Jokela, Maria Elo

Developing Innovative Business Models in Social Ventures

Bernardo Balboni, Guido Bortoluzzi

Business Model Adaptation and the Success of New Ventures 


\title{
Editorial
}

\section{Business Model Innovation - A Concept Between Organizational Renewal and Industry Transformation}

\author{
Jörg Freiling ${ }^{1}$
}

\section{THE GENERAL SETTING}

With the new millennium and the hype of electronic business a new movement was created that still gains momentum: business model innovations. Deeply influenced by business informatics in the early years, business models and business model innovations became a pervasive part of our business life. Particularly business model innovations opened the door for a thinking far beyond product and process innovations. By considering new ways of designing value propositions, value-added architectures and sales modes (e.g. Timmers, 1998), business model innovations became an attractive option of recent innovation management and strategic management of the entrepreneurial kind as well. Especially small- and medium-sized entities (SMEs) found a new way to innovate without spending too much resources in uncertain investments.

Once successfully implemented, business model innovations on the micro level drive organizational renewal and/or help in developing new businesses. More than that, business model innovations may change the 'rules of the game' in markets and trigger processes of industry transformation (Porter \& Rivkin, 2000) on the macro level.

Despite the considerable power of business model innovations, not every innovative business model is a 'home-run'. Empirical evidence suggests (e.g. Freiling \& Dressel, 2014) that sophisticated new business models promise 
'win-win' constellations for both customers and suppliers, but face the problem of limited adoption in target markets. Insofar, the implementation goes along with numerous obstacles. Little is said about the root causes of these obstacles and the ways how to cope with these challenges.

Many of the articles of this special issue address the background of business model innovations and open the door to new debates. This illuminates the rather inter-disciplinary nature of business model innovations that deal with different kinds of novelties for both suppliers and customers. Based on Schumpeter (1934), innovations may relate to products, processes, organizational modes as well as novel purchasing and distribution modes. These novelties are often interrelated and call for an over-arching frame. If well designed, business models can be such umbrellas and are, thus, useful elements of innovation and strategic management. More than that, they push forward the notion of systemic innovation as a core challenge for both strategic decision-making and innovation.

The papers deal with both customers and suppliers, as innovation cannot be separated from adoption processes in markets. In this regard, some former background issues come to the fore in this special issue, such as the still under-researched role of emotions (cf. Straker and Wrigley, 2015) and the role of diversity of people (particularly in the light of different cultural backgrounds - cf. Harima and Vemuri, 2015).

Innovating business models is among the priorities of leading companies in most recent times to keep a certain balance of value creation and value capture (Teece, 2010; Zott et al. 2011). While business model innovations require particular capabilities to develop new industry architectures (Jacobides et al., 2006; Freiling et al., 2008), business model innovation is a challenge that often returns to top positions of the management agenda. To change from one business model to another, however, is a different and often even more demanding challenge that is based on dynamic capabilities (Teece, 2007). By dynamic capabilities companies are able to sense and seize new business opportunities and to reconfigure the company. The bare existence of dynamic capabilities allows changing business models more proficiently and, thus, tapping the potential of new business opportunities (Müller and Vorbach, 2015).

However, while business model innovations have played a role in the entire economy in recent years, there are contexts where these innovative moves find a very fertile background. Without necessarily excluding other companies, particularly young firms seem to belong to these settings. Insofar, entrepreneurship and business model innovations are closely linked. One reason for this may be that incumbents are locked in their everyday business, reinforced by specific investments, and do not find enough time 
to go substantially beyond that. Thus, they are prone to attacks based on innovative business models of start-ups that are in need of doing something new and different to start launching their solutions in target markets. Entrepreneurship practice is full of examples where new ventures translated a basic innovation into a business model innovation to 'make' a market (e.g. Facebook, Amazon, Cirque du Soleil). The multitude of different ventures is hard to describe exhaustively, if it is possible at all. In this regard, it makes a difference whether the ventures are profit-oriented or non-profit ones. Papers of this special issue deal especially with this question (Jokela and Elo, 2015; Balboni and Bortoluzzi, 2015).

On a more pragmatic level, the question arises how to visualize the real nature of business models and how to plan and implement them. In literature, there is a huge variety of understandings - like Timmers' (1998) model of three business model components, the Morris et al. (2005) six-element approach or the nine-component 'business model canvas' framework of Osterwalder and Pigneur (2010). In this special issue, many articles adopted the more finegrained business model canvas approach that already penetrated business practice to some extent.

\section{THE PAPERS}

What falls short in research on business models, business model innovations and business model design, is the role of emotions. Karla Straker and Cara Wrigley uncover the role of emotion-driven innovations in their article on "The Role of Emotion in Product, Service and Business Model Design". They point to the need to build strong emotional connections with the customer by approaching visceral design, consumer hedonics and product rhetoric (VHR) issues. Whereas marketing research particularly in the realm of consumer behavior addressed the multiple emotional relations between products and customers, research on business model innovation is still silent in this regard. Their conceptual foundations are related to qualitative empirical research in eleven companies. The semi-structured interviews give rise to the impression that visceral, hedonic and rhetoric issues play a considerable role and deserve more attention when designing innovative products, services and business models.

If we move from the role of emotions to the role of intercultural skills and diversity of people driving businesses, the resources of migrants and, particularly in the article of Aki Harima and Sivaram Vemuri (2015), of diasporas come into play. "Diaspora Business Model Innovation", the official title of this contribution, refers to people with a double embeddedness: they migrate to a country of residence where they get used to and they still stay in touch with 
their country of origin. This kind of embeddedness enlarges the reservoir of business ideas and experience and may go along with favorable positions to develop and implement sometimes minor, sometimes major business model innovations. Building on empirical fieldwork in English schools in East Asia and structuring their considerations along the Osterwalder and Pigneur (2010) business model canvas, Harima and Vemuri (2015) compare diaspora and conventional English schools by their qualitative empirical studies.

In their article called "Enabling Business Model Change: Evidence from High-Technology Firms" Christiana Müller and Stefan Vorbach extend the debate on dynamic capabilities and their enabling role in business model change. They specify properties and capabilities that allow changing the elements or the entire design of business models. The findings are extracted from qualitative empirical research in high-tech industries predominantly in Western European countries.

In more recent times, there is a strong trend in business modeling and business model innovations to create critical mass effects and, thus, instant growth by the so-called 'freemium' approaches. Although not entirely new, this trend gained momentum in the 2000's by attracting and bonding customers long before first payments are made. Business reality developed a lot of examples. In earlier years, telecommunication providers gave away cell phones to charge customers heavily using these devices. Real pioneers of freemium models have been companies like Netscape or Adobe with basic versions for free and more sophisticated packages to be purchased. By now, there is a huge variety of freemium business models. Franziska GünzelJensen and Anna B. Holm illuminate this variety in their article on "Freemium Business Models as the Foundation for Growing an E-Business Venture: A Multiple Case Study of Industry Leaders". Moreover and in the center of their article, they address the growth of companies by implementing these business models. In this vein, they pay attention to the development of these business models over time - with an emphasis on initial life-cycle stages. The empirical background are four case studies of successful e-business companies.

Päivi Jokela and Maria Elo with their article "Developing Innovative Business Models in Social Ventures" open the door for business model innovations in case of the social entrepreneurship as a still up-and-coming field of entrepreneurial activities. It is evident that in terms of the business model canvas social ventures, driven by a social, mostly non-commercial mission, differ from profit-based start-ups in certain ways. The authors point out the very nature of business model innovations in case of social entrepreneurship and conduct qualitative empirical fieldwork based on the case study approach. 
Bernardo Balboni and Guido Bortoluzzi (2015) raise the question whether business model adaptations are related to the success of new ventures. In their article on "Business Model Adaptation and the Success of New Ventures" they particularly analyzed the impact of business model adaptations on survival in volatile settings, growth and profitability. Against this background, they point out the close connection between business model adaptations and the availability of dynamic capabilities in terms of Teece (2007). In this vein, they conducted case study-based empirical research by analyzing three Italian start-ups. The findings reveal that we must be cautious not to over-estimate the role of business model changes and innovations. While these adaptations help young firms to stay in competition, there does not seem to be an evident impact on typical performance measures like growth or profitability. Obviously, business model adaptations may go along with problems of converting market positions in financial performance - an interesting aspect that deserves more attention in future research.

\section{WHAT'S NEXT?}

It is by no means difficult to fill the research agenda of business model innovations with topics that deserve more attention. In this respect, many of the articles of this issue are simply door openers and call for follow-up contributions to continue. Besides that, the articles suggest over-arching topics that may stimulate further discussions. Among these issues, the core obstacles in reality of implementing business model innovations are still under-researched (Chesbrough, 2010; Freiling et al., 2015). A first few steps have been made, but there is still much more we should be aware of. Moreover, we can learn very much from failure. There are, in fact, numerous initiatives of business model innovations that finally failed - but often rather silently. It would be useful to uncover the hidden reasons for that by digging a little bit deeper based on empirical fieldwork.

When reading the papers of this special issue, another issue comes to the fore: business model innovation is, at first glance, a primarily explorative issue. However, business models, innovative or not, mark the line between strategy formation and implementation and call for regular adjustments and adaptations to fully reap the potential they bear. This, however, is closely related to exploitation that goes hand in hand with exploration and forms organizational ambidexterity (Tushman and O'Reilly, 1998; Gibson and Birkinshaw, 2004). How business model innovations are aligned and how transitions are managed, belongs to the topics that deserve more attention in future research. 
Moreover, the articles of this special issue often implicitly deal with the governance dimension of business model innovations. Obviously, business models innovations seem to favor network-like contexts and, particularly, platforms. It would be interesting to address this issue in future research more directly and more comprehensively than before.

A core challenge in researching business model innovations is the selection of appropriate research methods. In this special issues, the majority of articles adopted qualitative empirical research with a strong focus on case studies. However, as voiced by Harima and Vemuri (2015), we should not under-estimate the power of observations in the field. Sometimes the background of business model innovations is very complex and urges researchers to closely embedding themselves in the settings they want to investigate. However, the more we know about causal relationships in the realm of business model innovations, the more we can employ quantitative research. As business model innovations and adaptations are process phenomena with often long duration, path dependent effects and temporal interconnections, longitudinal research is among the future challenges as well. In sum, researchers on business model innovations are well advised to be open minded - in terms of methods and methodologies, as well as in terms of theories and theoretical approaches.

\section{References}

Balboni, B. \& Bortolouzzi, G. (2015). Business model adaption and the success of new ventures. Journal of Entrepreneurship, Management and Innovation 10 (this issue).

Chesbrough, H. (2010). Business Model Innovation: Opportunities and Barriers. Long Range Planning, 43(2-3), 354-363.

Freiling, J. \& Dressel, K. (2014). Exploring constrained rates of adoption of total cost of ownership models: A service-dominant logic analysis. International Small Business Journal 32, published online March 12, 2014, doi:10.1177/0266242613519118.

Freiling, J., Friedrich von den Eichen, S. \& Matzler, K. (2015). Why business model innovations fail. Journal of Business Studies (forthcoming).

Freiling, J., Gersch, M. \& Goeke, C. (2008). On the path towards a competencebased theory of the firm. Organization Studies, 43(8/9), 1143-1164.

Gibson, C. B. \& Birkinshaw, J. (2004). The antecedents, consequences, and mediating role of organizational ambidexterity. Academy of Management Journal, 47(2), 209-226.

Günzel-Jensen, F. \& Holm, A. B. (2015). Freemium Business Models as the Foundation for Growing an E-Business Venture: A Multiple Case Study of Industry Leaders. Journal of Entrepreneurship, Management and Innovation 10 (this issue). 
Harima, A., Vemuri, S. (2015). Diaspora business model innovation. Journal of Entrepreneurship, Management and Innovation 10 (this issue).

Jacobides, M., Knudsen, T. \& Augier, M. (2006). Benefiting from innovation: Value creation, value appropriation and the role of industry architectures. Research Policy 35, 1200-1222.

Jokela, P. \& Elo, M. (2015). Developing innovative business models in social ventures. Journal of Entrepreneurship, Management and Innovation 10 (this issue).

Morris, M., Schindehutte, M. \& Allen, J. (2005). The entrepreneur's business model: Toward a unified perspective. Journal of Business Research, 58(6), 726-735.

Müller, C. \& Vorbach, S. (2015). Enabling business model change: Evidence from high-technology firms. Journal of Entrepreneurship, Management and Innovation 10 (this issue).

Osterwalder, A. \& Pigneur, Y. (2010). Business model generation, New York: Wiley.

Porter, M. E. \& Rivkin, J. W. (2000). Industry transformation. Boston/Mass.: Harvard Business School Publications.

Schumpeter, J. A. (1934). The theory of economic development. Cambridge, MA: Harvard University Press.

Straker, K. \& Wrigley, C. (2015). The role of emotion in product, service and business model design. Journal of Entrepreneurship, Management and Innovation 10 (this issue).

Teece, D. J. (2007). Explicating dynamic capabilities: the nature and microfoundations of (sustainable) enterprise performance. Strategic Management Journal, 28(13), 1319-1350.

Teece, D. J. (2010). Business models, business strategy and innovation. Long Range Planning, 43, 172-194.

Timmers, P. (1998). Business models for electronic markets. Electronic Markets, 8(2), 3-8.

Tushman, M. L. \& O'Reilly, C. A. (1996). Ambidextrous organizations: Managing evolutionary and revolutionary change, California Management Review 38(4), 8-30.

Zott, C., Amit, R., \& Massa, L. (2011). The business model: Recent developments and future research. Journal of Management, 37(4), 1019-1042.

\section{Biographical note}

Jörg Freiling is Head of the Chair of Small Businesses \& Entrepreneurship (LEMEX) at the University of Bremen, Germany. Simultaneously, he is Vice Dean of the Faculty for Business Studies and Economics. Jörg Freiling acquired his PhD in Business \& Economics and his Habilitation (Second Doctorate) at Ruhr University of Bochum, Germany. He was Visiting Professor at several universities is (co-)editor of international journals in business studies. His research focuses business model innovation, international entrepreneurship, 

Industry Transformation

start-up ecosystems, entrepreneurial failure, governance of transnational companies, entrepreneurship theory and strategic real options thinking. 


\title{
The Role of Emotion in Product, Service and Business Model Design
}

\author{
Karla Straker ${ }^{1}$, Cara Wrigley ${ }^{2}$
}

\begin{abstract}
Designers have become aware of the importance of creating strong emotional experiences intertwined with new tangible products for the past decade, however an increased interest from firms has emerged in developing new service and business models as complimentary forms of emotion-driven innovation. This interdisciplinary study draws from the psychological sciences - theory of emotion - and the management sciences - business model literature to introduce this new innovation agenda. The term visceral hedonic rhetoric (VHR) is defined as the properties of a product, (and in this paper service and business model extensions) that persuasively induce the pursuit of pleasure at an instinctual level of cognition. This research paper lays the foundation for VHR beyond a product setting, presenting the results from an empirical study where organizations explored the possibilities for VHR in the context of their business. The results found that firms currently believe VHR is perceived in either their product and/or services they provide. Implications suggest shifting perspective surrounding the use of VHR across a firm's business model design in order to influence the outcomes of their product and/or service design, resulting in an overall stronger emotional connection with the customer.
\end{abstract}

Keywords: visceral hedonic rhetoric, emotional design, business innovation, service design, business model design.

\section{INTRODUCTION}

Studies have found that $80 \%$ of an individual's life is consumed by emotions while the other $20 \%$ is intellect (Lough, 2006). Damasio (1999) states that $85 \%$ of thought, emotion and learning occur in the subconscious mind, beyond the reach of rationalization or reasoning. This could be due to the emotional part of the brain being larger, and therefore tends to dominate over the rational brain and control the thought process of individuals (Abraham,

1 Karla Straker, Queensland University of Technology, Queensland, Australia, Tel. +61731389471, e-mail: k.straker@qut. edu.au.

2 Cara Wrigley, Dr, Senior Lecture, Design-led Innovation, Queensland University of Technology, 2 George St, Brisbane, Australia, Tel. +61731389471, e-mail: cara.wrigley@qut.edu.au. 
1999; Kunnanatt, 2004). The emotional connection between a customer and product is one of complicated behaviour and multifaceted reasoning, yet is powerful enough to entice customers to choose one product over another (Forlizzi, Disalvo and Hannington, 2000). This in turn has led to designers designing products that target customer emotions, specifically with the aim to induce a strong user-product attachment (Desmet, 2002). According to Norman (2004) the field of design and emotion comprises of elaborate human behaviours, involving emotional processing, immersed in this is the level of visceral cognition (Norman, 2004). Product designers have become aware of the importance of creating strong emotional experiences intertwined with new tangible products for the past decade (Jordan, 2000; Norman, 2004). However, as current as this field is, a lack of theoretical precision exists in the instalment of emotional design (Forlizzi, Disalvo and Hannington, 2000) beyond product innovation alone.

The term visceral hedonic rhetoric (VHR) is defined as the properties of a product (and proposed in this paper, services and business model design) that persuasively induces the pursuit of pleasure at an instinctual level of cognition (Wrigley, 2013). Emotions can influence the success in product innovation by customer attraction and purchase decisions. An increasing interest from research and industry has emerged in developing new services and business models as complimentary forms of innovation in order to create emotional connections with customers. Even though designers have considered the role of emotions in products and developing customer services, the design of business models that incorporate emotions is not yet well understood. However, when generating new products and or services, the design of a business model is just as important for success due to creating a desired response from the customer. As consumers' emotions have a significant influence on purchase and consumption decisions for a wide variety of products, emotional needs lay at the foundation for consumers making purchase decisions. Hill (2010) also expresses that selling consumers on what they already believe and feel is easier than changing that persons' belief. O'Shaughnessy and O'Shaughnessy (2003) argue that emotions will always be a factor in consumer decision-making and that consumers constantly make decisions surrounding the selection, consumption and disposal of products. Therefore, appealing to a prospective consumer's emotional needs is the key action leading to the purchase of a product.

An investigation of VHR in response to a variety of products, services and business models was conducted with seven Australian small to medium enterprises and four multi-national firms to understand their views of what VHR meant in the context of their businesses and how they could perceive it adding value in the future. Semi-structured interviews were conducted with 
company employees after an introduction workshop to define what VHR was as a concept. The research of VHR is of vital importance not only to the design discipline but also to business model design innovation due to the opportunity to create powerful emotional connections between consumers and companies.

\section{Emotional design}

Emotional design is described as the emotional connection humans have to everyday objects and products (Norman, 2004). There has been a steady growth in design and emotion research since its' emergence in 1999, which has focused on understanding the emotions elicited during the use of a product and developing tools and techniques that facilitate an emotion-cantered design process (Desmet, 2002). Noteworthy authors within this field include Norman (2002), Desmet (2002) and Jordan (2000) who have investigated a range of areas including the cognitive process, the design of products and the design of the user's experience and interaction with a product. In Norman's (2004) research it is questioned why washing and polishing your car make it drive better and explores why attractive objects provide the sometimes illusory, sometimes real, effect of superior function. A review of the body of research in the area of design and emotion reveal a general consensus that an individual reacts to the world through his or her emotions, and that stimuli such as arousal, action tendency and subjective feeling (pleasant or unpleasant) evoke emotions in all individuals (Weerdesteijn, Desmet and Gielen, 2004). Additionally, emotions are implicated into all aspects of daily life (e.g. mood, cognition, behaviour, attention, perception and memory) and influence everyday activities and interaction between people, products and the environment.

\section{Visceral hedonic rhetoric (VHR)}

Visceral hedonic rhetoric originated form the combination of visceral design, consumer hedonics, and product rhetoric (conglomerate VHR) areas of research. Norman (2004) describes visceral design as the cognitive examination of immediate responses enabling users to react to visual and other sensory aspects of a product before considerable contact transpires. This is an experience that consumers are powerless to dictate and are often unaware of its occurrence as it is embossed in the unconscious psyche of the user (Norman, 2004). Many authorities have tried to define visceral design due to its use in many different contexts and across a broad scale and spectrum (Loewenstein, 1996). From the reviewed literature, the information regarding visceral design is fairly broad and no case study has been found 
that focuses entirely on visceral design or visceral hedonics. Add this to the apparent lack of research linking visceral hedonic responses to products and their consequent design properties, the need for understanding in this subject becomes quite considerable.

Hedonics can be defined as the branch of psychology that studies the mind's pleasant and unpleasant sensations and has been identified as anything relating to the pursuit of pleasure (Hirschman and Holbrok, 1982). Hedonics is also significantly influential to consumers. The customers' choices and decisions are made to purchase a product for their enjoyment, pleasure and excitement is derived from the emotional design of the product (Barrett, Mesquita, Ochsner and Gross, 2007). While consumers have often reported wanting functional or tangible attributes when purchasing products, there is also a demand for a hedonic or satisfying emotional response and experience when using a product. Hedonic behaviour in consumers relates to aspects of the product purchase and handling experience, and to the multi-sensory, fantasy and emotive aspects of product usage (Hirschman and Holbrok, 1982). Inevitably hedonics is important to a product's success and is considered in the design industry as the pursuit of pleasurable design (Porter, Chiber and Porter, 2004). From the literature examined there remains a need to separate and compare responses and to determine their causes as this still presents a significant gap in the field of hedonics. It is an issue that must be thoroughly addressed if any significant emotional contribution to design is to be made (Jordan, 2000).

Throughout history, rhetoric has been defined as the art of speaking well or the art of persuasive verbal communication. Over the years it has developed interdisciplinary associations with the common goal of effective communication (Erlhoff and Marshall, 2007). Today, rhetoric is undergoing a new era of research and development, with designers helping to shape it to meet contemporary demands (Kaufer and Butler, 1996). If designers can benefit from rhetorical insights, then design can continue to influence and form society through its persuasive assertions. Uncovering what designers need to discover is an entirely new aspect of demonstrative rhetoric that will significantly affect the understanding of product influence in the future. Product rhetoric provides literature with persuasive product design properties and focuses on the features that enable products to communicate convincingly. In relation to visceral hedonics, it grounds the study in the field of product design.

Wrigley $(2013$, p.43) revealed the gap of the combination of VHR where it was defined as "properties of a product that persuasively elicit the pursuit of pleasure through an instinctual level of cognition". In this definition, "properties of a product" refer to a product's physical attributes, such as 
size, material, colour, smell, form and other distinguishing features. It is the proposition of this paper that a combination of visceral design, consumer hedonics and product rhetoric, can assist in the design of novel products, services and business models, which are required for more competitive business strategies.

\section{Visceral hedonic rhetoric beyond products}

Visceral hedonic rhetoric has been contextualised through the use of interactive consumer products (Wrigley, 2011). However, pursuing VHR throughout services and business models is needed to sustaining an emotional connection with consumers. There is an abundance of research into design and emotion outlining many important findings and implications for product design, but much less on services, and even less or next to none on business models (Bucolo and Wrigley, 2012). Goddin, Varnes, van der Hoven and Koners (2012) explain that companies that provide services, rather than tangible products face the challenge in acquiring insight into customer's needs, due to services intangibility, inseparability and heterogeneity (each service employee and each customer interaction is different) (Johnson, Christensen and Kagermann, 2008).

Beyond product design, authorities have established and explored emotion through various fields such as branding and customer loyalty (Hill, 2010; Robinette, 2003), marketing (O'Shaughnessy \& O'Shaughnessy, 2003) and customer services (Roberts, 2005). The interaction a company has with a customer can all affect a customer's emotion (Roberts, 2005), this expands from a customer visiting a store or web site to employee interaction and communications to loyalty programs. Robinette $(2003$, p.4) believes that "in every encounter there's an opportunity to meet a need and make an emotional connection" with the customer. Robinette (2003, p. 4) discusses emotional marketing, which is the "wide pursuit of a sustainable connection that makes customers feel valued and cared for that they will go out of their way to be loyal". Robinette (2003) elevates emotion to the strategic level, recognising its importance in creating or strengthening a relevant brand identity and managing a customer's experience. There are many examples of companies who have been successful at emotional marketing, such as, Hallmark, Fed-ex, Walgreens pharmacy and Starbucks (Robinette, Brand, Lenz and Hall, 2000), due to them exceling in providing excellent customer service. Roberts (2005) believes brands can be transformed into Lovemarks that people fall in love with. In order for a brand to be a Lovemark it needs to connect companies, their customers and brand to create loyalty beyond reason as they are owned and used by customer who love them (Roberts, 2005). Caring is essential to 
loyalty therefore companies must go beyond seeking customer satisfaction to showing customers they genuinely care (Roberts, 2005; Robinette, 2003).

Hill (2010, p.226) explains, "Nothing is more emotional for consumers or dangerous for companies than an unsatisfied customer". The interaction with a customer through visiting a store or web site, employee contacts, communications and loyalty programs can all affect a customer's emotion (Roberts, 2005). Trust and emotion become important mediators in the service recovery process (DeWitt, Nguyen and Marshall, 2008). Therefore, the role the salesperson plays is critical in communicating emotional brand values (Lynch and De Chernatony, 2004), however is often an overlooked aspect in business management and strategy.

Norman (2004) states "everything that we do, everything we think is tinged with emotion" and it is for this reason that companies need look beyond product offerings for understanding the real needs of consumers (Crossley, 2002). In a study involving 23,000 American consumers, it was concluded that emotions are twice as important as facts in the decision buying process (Morris, Woo, Geason and Kim, 2002). The creation of value through emotion is not only important in products and service but also throughout the company. According to Teece $(2010$, p.172) the core of a business model design is the way in which a company delivers "value to customers, entices customers to pay for value, and converts those payments to profit". It therefore reflects management's hypothesis about what customers want, how they want it, and how the enterprise can organize to best meet those needs (Teece, 2010). The purpose and key aspects of a business model are often agreed upon through literature, as the notion of value, either as value proposition, value stream or value chain (Chesbrough and Rosenbloom, 2002; Osterwalder and Pigneur, 2010; Zott, Amit and Massa, 2010). Zott, Amit and Massa (2010) explain that a primary characteristic of a new business model is the creation and capture of value to occur in the value network. This value network can include suppliers, partners, branding, service model, funding, distribution channels and activities (Bucolo and Wrigley, 2012; Zott, Amit and Massa, 2010). The notion of value creation is an impacting driver in a business model, however the role of emotion throughout a business value chain or business model design is not yet well understood. However, in the branding arena emotions can represent a measure of attachment that a customer has to the business/brand, reflecting the likelihood of engagement in the experience, leading to recurring purchase (Ghodeswar, 2008). Keller and Lehmann (2003) propose that the customer mind set is the key driver of brand performance. If the customer is engaged in the experience and brand over recurring engagements, it has the potential to have a significant effect on the perception of the brand (Verhoef et al., 2009). However, with the 
growing amount of product, service offerings, companies are faced with the challenge to unify their brand value across multiple fronts in a way that is consistent in engaging their customers.

\section{A strategic approach}

The evidence presented suggests that VRH has been studied predominately from a product design predisposition while research is yet to be conducted from a business model viewpoint. Norman (2010, p.40) states "innovation is a systems issue; it is not about product or process, but the entire system". Teece (2010, p.3) also expresses "without a well-developed business model, innovators will fail to either deliver or to capture value from their innovations". Business models can be described as corporate blueprints for how to conduct business and generate revenue (Osterwalder and Pigneur, 2010). In Osterwalder's business model canvas, the nine elements are resources, activities, partners, value proposition, customers, delivery channels, customer relationships, cost structure, and revenue stream. The purpose of a business model is to understand what value is provided to the customer (Osterwalder and Pigneur, 2010), which products or services are then designed to produce a proposition of value to customers (Demil and Lecocq, 2010). A business model of a firm constitutes multiple value creation processes, which is partly; branding, service model, funding, distribution and activities (Bucolo and Wrigley, 2012), there is a need to better understand the relationship between these elements, emotions and the customer. Bucolo and Wrigley (2012) suggest the creation of an emotional business model to encouraged firms to firstly identify and then better understand the needs of their stakeholders. The results or outcome of this emotion business model are opportunities that clearly link the functional aspects (product or service) of the business model to emotion aspects of the customer. Focusing explicitly on a firm's capacity to build emotional connections across their value chain ensures this. The successful application of this can be a powerful competitive advantage as it's almost impossible to replicate (Robinette, 2003). As any competitor can match functional and technical characteristics, however, they cannot easily match the emotional experience promised (Lynch and De Chernatony, 2004). Hill (2010) explains that all too often companies choose what their product or service is over who their customer is, for competitive advantage. Bucolo and Wrigley (2012) suggest the creation of an emotional business model to encouraged firms to firstly identify and then better understand the needs of their stakeholders. The results or outcome of this emotion business model are opportunities that clearly link the functional aspects (product or service) of the business model to emotion aspects of the customer and internal operations. 
An example of an emotional business model can be demonstrated through the comparison of Apple and Samsung mobile phones. Both are suitable (aesthetically pleasing and functional) designs at a product level, however Apple continues the notion of emotion throughout its' entire business model. The Apple brand is a Lovemark, it is a brand that consumers love because the branding or experience felt is consistent from the product, to the packaging, to the marketing messages and continues to the experience of walking into an Apple retail store. While Samsung can compete on a product level, it is unable to provide the same customer experience as Apple in western markets. Focusing explicitly on a firm's capacity to build emotional connections across their value chain can ensure the creation of an emotional business model. Lynch and De Chernatony (2004) explain that attention needs to be given to (company) values to ensure that they are communicated not only externally but also within the organisation. As consumers buy brands that provide emotional reinforcement and are aligned with core beliefs that are built upon core emotions (Hill, 2010). The successful application of this can be a powerful competitive advantage as it is almost impossible to replicate (Robinette, 2003). The aim of this research was to understand this further by exploring the current perspective of VHR responses in the context of a range of businesses. In addition this research aims to present new insights and understandings of VHR for the design of future products, services and business models, with a variety of visceral hedonic responses explored.

\section{Research approach}

Participants of this study were firm representatives from four multi-national companies and seven Australian small to medium enterprises (SMEs) firms from a variety of different industries, including product manufactures, financial institution to utility providers (Table1). Specifically, this paper reports the findings on VHR within a larger research project that traced the process and progress of re-framing design more strategically in their organisation.

Table 1. Participant and organization summary

\begin{tabular}{llll}
\hline No & Industry Sector & Size & Firm Participants \\
\hline 1 & Transportation & Multi-National & Marketing Manger \\
2 & Healthcare & Multi-National & Marketing Manger \\
3 & Infrastructure & Multi-National & R\&D Manger \\
4 & Insurance & Multi-National & Product and Service Manager \\
5 & Manufacturing & SME & Sale Manager \\
6 & Manufacturing & SME & Product Manger
\end{tabular}




\begin{tabular}{llll}
7 & Manufacturing & SME & Brand Strategist \\
8 & Finance and banking & SME & Product Manger \\
9 & Manufacturing & SME & Director \\
10 & Manufacturing & SME & Engineering Manger \\
11 & Manufacturing & SME & R\&D Manager \\
\hline
\end{tabular}

\section{Method}

All participants (identified in Table 1) took part in a short workshop before the one on one interview was conducted. The workshop gave an introduction to visceral design, consumer hedonics and product rhetoric. Participants were able to ask questions to clarify any issues on their understanding of VHR before the interview. Data was collected through semi-structured interviews in which participants were asked a set of questions on:

1) How they thought VHR currently fits in their company. This included asking where they positioned it (operational or strategic).

2) Their perceptions on the importance of visceral, hedonic and rhetoric in regards to the company.

3) What emotions they think and what they want their customer to feel in relation to their products, services and overall company.

The eleven interviews sought to gain company perspectives from employee instead of their customers. Their initial expectations, perceptions and the value of VHR were explored. The semi-structured interviews were conducted in a face-to-face setting lasting approximately sixty minutes each. Responses were recorded and transcribed with participant consent (Myers, 2009). Investigator triangulation was utilized by each researcher conducting the interviews (Collins, 2010). Transcripts were then analyzed using a thematic approach (Braun and Clarke, 2006; Miles and Huberman, 1994) to uncover consistent themes. Identifiable firm intellectual property was excluded from the analysis for ethical purposes. As this data did not align to the scope of the study, exclusion has not impacted the reported findings. The analysis was completed by the research team using grounded theory, first, to identify codes, second, to group codes into similar concepts and third, to group comparable concepts to generate theory (Miles and Huberman, 1994). The use of analysis triangulation allowed each researcher to both analyze the results separately and amalgamate data to validate findings.

The limitations of this research need to be acknowledged, with further research required to develop an extensive and deeper understanding of VHR in products, services and business models. The smaller sample size is due to strict time constraints and the time intensive methodology and analyses approach. This does limit the ability to generalize results, however, provides 
richer, in-depth information, which the authors believe to be critical in achieving a deeper understanding of VHR in a product, service and business model design context. This research was conducted with employees of the respective firms to understand the emotional perceptions of their products, services and business models. A limitation of this approach is not gaining insights from customers of the target group of products and services. Employee views may be swayed by information asymmetries and group dynamics.

\section{RESULTS}

Results reveal how VHR was perceived in the context of a firm and have been separated in the perceived categories (i) Product (ii) Service (iii) Business model. Table 2 illustrates some sample responses to demonstrate the categorisation.

Table 2. Example participant responses

\begin{tabular}{|c|c|c|c|}
\hline & Product & Service & Business Model \\
\hline Visceral & $\begin{array}{l}\text { "I can't have this meal } \\
\text { without this product" }\end{array}$ & $\begin{array}{l}\text { "Reliability is KING and we } \\
\text { do everything to sort out } \\
\text { loss of service" }\end{array}$ & $\begin{array}{l}\text { "Brand choice on } \\
\text { aesthetic of product" }\end{array}$ \\
\hline Hedonic & $\begin{array}{l}\text { "Make a decision } \\
\text { based on the physical } \\
\text { appearance of the } \\
\text { luminaries" }\end{array}$ & $\begin{array}{l}\text { "Displeasure being } \\
\text { 'sterilised' through } \\
\text { security" }\end{array}$ & $\begin{array}{l}\text { "Nostalgic- a brand I grew } \\
\text { up with" }\end{array}$ \\
\hline Rhetoric & $\begin{array}{l}\text { "This is for mostly a safety } \\
\text { requirement"" }\end{array}$ & $\begin{array}{l}\text { "Crucial part of the } \\
\text { installation process" }\end{array}$ & $\begin{array}{l}\text { "Security, trusted } \\
\text { Australian, plan for goals } \\
\text { future" }\end{array}$ \\
\hline VHR & $\begin{array}{l}\text { "Currently very little } \\
\text { consideration is given } \\
\text { to the user's emotional } \\
\text { experience when using the } \\
\text { product" }\end{array}$ & $\begin{array}{l}\text { "In this case VHR } \\
\text { essentially means making } \\
\text { the sales/ installation } \\
\text { process as easy as } \\
\text { possible" }\end{array}$ & $\begin{array}{l}\text { "I'm not entirely sure how } \\
\text { to apply VHR to business } \\
\text { strategy" }\end{array}$ \\
\hline
\end{tabular}

\section{The applicability of VHR}

When asked about VHR in the context of their firms, two participant's responses included: "VHR is essentially an ideal that would be nice to consider. The importance of emotion and user experience is somewhat understood, however it is currently an afterthought at best" and "VHR- we try to do this we know we have to, we struggle with it, it sits behind every other product requirement". The others firm representatives responded by associating the value of VHR strongly with one aspect of their company. A product-manufacturing firm remarked, "Since (our company) produces products to be used by people, I 
think VHR is most important to the product itself in order to create an emotional connection between the end user and product". A product manufacturing firm which provides an installation service commented, "customers and installers, consideration is given to the service (our company) can provide to them". While a business-to-business firm stated, "Business - we need to make businesses want to do business with us, they bring the customers".

\section{Product}

Overall the participants found it easiest responding to the visceral and hedonic responses through their products. Immediate (visceral) responses included; "I can't have this meal without this product" and "Customers make a decision based on the physical appearance of the luminaries". Some participants could state clearly how VHR could or is present in their product, while others stating it not to be a focus at all. One participant believed it to be only present in the product as it was not considered in other aspect of their business, "It is most important through the product, but this is currently the situation merely because it is the only context where these factors are being considered". A different firm understood what their organisations value proposition was however it was not reflected in practice, "the company's value proposition for the end user is centered around lifestyle, which is inherently emotional, however this is not really reflected in the design process". While another firm commented that the product was not a focus of their firm or VHR associated with it, "Currently very little consideration is given to the user's emotional experience when using the product... this is not the focus".

\section{Service}

The important of VHR became very apparent in service-based companies through the installation and maintenance process. Rhetoric was mostly associated with this area of the firm, "Product rhetoric is a crucial part of the installation process... However the end user will not be harvesting any benefits of good rhetoric". Many firms made the connection of VHR through the service of installation and maintenance their firms provided for their product. A participant associated VHR not with their customers but with the firm's employees, "in this case VHR essentially means making the sales/ installation process as easy as possible". However, in another firm that did not provide a tangible product but a service, that representative commented, "VHR is more important to (our company) through service, this is what people see, the guys fixing the issues as they arise and they save the day". Within the same firm it was said when this service cannot be supplied, "then the VHR is possibly very clear from the customer, it is not here and I am not happy". 


\section{Business model design - branding}

All participants had a harder time finding the VHR association with their overall business model, with a participant responding; "I'm not entirely sure how to apply VHR to business strategy". A common association of visceral and hedonic was through particular elements of a business model, the most common being branding. One participant responded, "It's a brand I grew up with" and in which he explain that it resonated with a lot of customers as nostalgia. Another response included "brand, lack of attachment" explaining that currently the firm representative feels customer have no attachment with their brand. The third connection of brand was through the choice of aesthetic products the firm offered its customers. Another element of the business model design that other firm representatives touch upon was their value proposition. Many believed that customers connected with their firm through what it meant to them. Words used to represent these values included security, protection, nostalgic, trusted and reliable. The last connection to a business model design element was included key partners, "partnership as power generation and storage becomes decentralized". Overall a firm representative commented that finding out more insights about VHR and its position within in their firm, "would make a great and crucial impact on the business model itself, which could lead to a positive change in the physical products".

\section{Discussion}

The research of VHR is of vital importance to the design of products, services and business model designs due to the possibility of creating powerful emotional connections between customers and companies. However, the results found that how firms perceived the applicability of VHR many admitted they struggled to execute this correctly. Results also related strongly to the type of business they were in. Such as in the product-manufacturing firms VHR was predominately positioned at the product level, while service based firms positioned it within their customer service departments and systems. It could be argued that this is due to the intangibility of services and therefore the firm perceived it to be less of a visceral response and more emphasis was placed on hedonistic experience. This highlights the imperative nature of the conglomerate area of VHR as visceral responses occur also in intangible services. Firms in product manufacturing particularly had trouble articulating how it could fit into services or the business model design of their firms. This could be referred to as a visceral response as products are tangible objects, and allow for an immediate connection to be made with an emotion. While firms who provide services and products found that VHR was easily related, 
not to the customer but through the employees of the firms providing maintenance or installation. In these cases VHR became a large influence in responses from participants as communication of providing how to install or maintain products became the focal point. This was perhaps understood as rhetoric - an element that aims to provide successful communication. However, in terms of VHR, rhetoric is associated with the goal of providing strategically effective communication, as in having a persuasive assertion.

Firms who provide a service faced the challenge in acquiring insight into customer needs (Goffin, Varnes, Van der Hoven and Koners, 2012). Due to service intangibility, the service experience can vary due to inconsistencies such as interaction with service employees (Johnson, Christensen and Kagermann, 2008). DeWitt, Nguyen, Marshall (2008) respond to how service failure can influence a customers' emotional state. In a participant's response it was discussed that the failure of the service provided a high degree of emotional response from customers, but when the service was stable there was little response from customers. However, the participant commented that the firm has the opportunity to incorporate VHR when a failure occurs. In this company the service response teams were seen as heroes, changing the emotions customers associate with the service failure. DeWitt, Nguyen, Marshall (2008) believe that influencing a customer's emotional response is an important mediator in the service recovery process.

As discussed the use of a tangible product made it easier for respondents to make a connection with a product vertical, however, in relation to the business model design, many emotional connections can be made with all nine elements of the business model. Interview participants related visceral, hedonic and rhetoric to the value proposition, key partners and channels in their business models. The strongest was through branding. Authorities (DeWitt, Nguyen, Marshall, 2008; O'Saughnessy and O'Saughnessy, 2003; Roberts, 2005; Robinette, 2003) discuss the emotional connection through branding as a way for creating customer loyalty. One participant spoke of his own personal nostalgia towards the firm's brand, which could be explored through VHR as a way to create a strong emotional connection with customers. As using emotions as a strategy is a possible solution to sustaining customers or creating new customer through positive product or service experiences. None of the participants commented on the experience of their customers, overall emotions were only related to the product or services. While consumers have often reported on wanting functional or tangible attributes when purchasing products, there is also a demand for a hedonic or satisfying emotional response and experience when using a product.

In order to make an emotional connection with a customer, a firm must first be able to associate emotions into their business model. Doing 
so involves shifting a firm's immediate response on VHR from products or services into a business model focus. Focusing explicitly on a firm's capacity to build emotional connections across their value chain will provide powerful competitive advantage as it almost impossible to replicate (Robinette, 2003). However, this requires a deeper exploration of a firm's business model. It was found that firms struggled to articulate the emotional aspects of their firms, therefore tools and methods such as Value Star Method (Robinette, 2003), Lovemark (Roberts, 2005) and Emotional Business Modeling (Bucolo and Wrigley, 2012) should be utilised to understand their customer and value proposition.

\section{CONCLUSION AND FUTURE RESEARCH}

Designers have become aware of the importance of creating strong emotional experiences intertwined with new tangible products for the past decade, this was seen in the results the perceived role of VHR had been associated highly with products. However, it is the view of the authors that there must be a common relationship of VHR through the design of products, services and business models. The primary motivation for this paper was to explore VHR and its role beyond product design. It is the proposition of this paper that a combination of the visceral design, consumer hedonics, and product rhetoric categories, can assist in the innovation process within an organisation. The results show that firm representatives currently believe VHR is evident in either their product and/or services. There remains a gap as to how businesses are able to undertake business model design through the understanding and integration of VHR. Further research will therefore be conducted to investigate these propositions in depth to gain an understanding how the integration of VHR can facilitate business model design. A shift in perspective of the use of VHR across all the elements of a firm's business model is suggested to influence the outcomes of their product and/or service they provide to have a stronger emotional connection with their customers. As $80 \%$ of a consumer's life is consumed by emotions while the other $20 \%$ is intellect (Lough, 2006), generating new products, services or business strategies it is important to consider emotions to create the desired response from the consumer.

There is rich research into design and emotion that outlines tools and methods for designing for emotional experiences, however, less is known in relation to the integration of VHR through business models. Implementing VHR within the creation and development of a business model could facilitate business innovation through the expansion of consideration of customer emotions beyond just a product offering. However, to achieve this, the 
authors propose a series of iterative experiments instead of implementing a linear approach. Rather than writing a static business model that have little or no basis in reality, an emotional approach requires a series of prototyped business models to be tested and validated with customers. The objectives of this research were to explore VHR responses within a business context while the future conclusions of this research present new insights and understandings of VHR for the design of future products, services and business models, with a variety of visceral hedonic responses. This will not only assist the immediate industry of product design but the wider design and business innovation domain. It is anticipated to offer a greater perspective in the use of VHR as well as avenues for further investigations.

\section{References}

Abraham, R. (1999). Emotional intelligence in organizations: A conceptualization. Genetic, Social, and General Psychology. Monographs, 125, 209.

Barrett, L., Mesquita, B., Ochsner, K., \& Gross, J. (2007). The Experience of Emotion. Annual Review of Psychology, 5(8), 373-403.

Braun, V., \& Clarke, V. (2006). Using thematic analysis in psychology. Qualitative Research in Psychology, 3(2), 77-101.

Bucolo, S., \& Wrigley, C. (2012). Using a design led approach to emotional business modelling. In Leading Innovation through Design: Proceedings of the DMI 2012 International Research Conference, Boston, MA, USA, 323-333.

Chesbrough, H., \& Rosenbloom, R. (2002). The role of the business model in capturing value from innovation: evidence from Xerox Corporation's technology spin off companies. Industrial and Corporate Change, 11(3), 529-555.

Crossley, L. (2002). Building Emotions in Design. The Design Journal, 6(3),3545.

Damasio, A. (1999). The Feeling of What Happens: Body and Emotion in the Making of Consciousness. Harcourt: New York.

Demil, B., \& Lecocq, X. (2010). Business Model Evolution: In Search of Dynamic Consistency. Long Range Planning, 43(2-3), 227-246.

Desmet, P. (2002). Designing Emotions. Delft: Delft University of Technology.

DeWitt, T., Nguyen, D. T., \& Marshall, R. (2008). Exploring Customer Loyalty Following Service Recovery: The Mediating Effects of Trust and Emotions. Journal of Service Research, 10(3), 269-281.

Erlhoff, M., \& Marshall, T. (2007). Design Dictionary. Birkhauser.

Forlizzi, J., Disalvo, C., \& Hanington, B. (2000). On the relationship between emotion, experience and the design of new products. The Design Journal, $6(2), 29-38$. 
Ghodeswar, B. (2008). Building brand identity in Competitive markets: A conceptual model. Journal of Product and Brand Management, 17(1), 4-12.

Goffin, K., Varnes, C. J., Van der Hoven, C., \& Koners, U. (2012). Beyond the Voice of the Customer: Ethnographic Market Research. ResearchTechnology Management, 55(4), 45-54.

Hill, D. (2010). Emotionomics: Leveraging Emotions for Business Success. Kogan Page: London.

Hirschman, E., \& Holbrok, M. (1982). Hedonic Consumption: Emerging Concepts, Methods and Propositions. Journal of Marketing, 46(3), 92101.

Johnson, M. W., Christensen, C. M., \& Kagermann, H. (2008). Reinventing Your Business Model. Harvard Business Review, (December), 86(12), 57-68.

Jordan, P. (2000). Designing Pleasurable Products. Taylor and Francis: New York.

Kaufer, D., \& Butler, B. (1996). Rhetoric and the art of design. Lawrence Erlbaum Associates Publishers: New Jersery.

Keller, K. \& Lehmann, D. (2003). How Do Brands Create Value? Marketing Management, 12(3), 26-31.

Kunnanatt, J. T. (2004). Emotional intelligence: The new science of interpersonal effectiveness. Human Resource Development Quarterly, 15(4), 489-495.

Loewenstein, G. (1996). Out of Control: Visceral Influences on Behaviour. Organizational Behaviour and Human Decision Process, 65(3), 272-292.

Lough, W. (2006). Once more with feeling. Knoxville: University of Tennessee. Lynch, J., \& De Chernatony, L. (2004). The power of emotion: Brand communication in business-to-business markets. Journal of Brand Management, 11(5), 403-419.

Magretta, J. (2002). Why business models matter. Harvard Business Review, 80(5), 86-92.

Morris, J., Woo, C., Geason, J. A., \& Kim, J. (2002). The Power of Affect: Predicting Intention. Journal of Advertising Research, 42(3), 7-17.

Norman, D. (2002). The design of everyday things. Basic Books: New York.

Norman, D. (2004). Emotional Design. Basic Books: New York.

Norman, D. (2010). Technology first, Needs last: The research-Product Gulf. Interactions, 17(2), 38-42.

O'Shaughnessy, J., \& O'Shaughnessy, N. J. (2003). The Marketing Power of Emotion. Oxford University Press: New York.

Osterwalder, A., \& Pigneur, Y. (2010). Business Model Generation: A Handbook for Visionaries, Game Changers, and Challengers. John Wiley \& Sons Ltd: UK.

Porter, S., Chibber, S., \& Porter, J. (2004). Towards an understanding of pleasure in product design. In Design and Emotion. CRC Press, 342-347.

Roberts, K. (2005). Lovemarks. PowerHouse Books: UK. 
Robinette, S., Brand, C., Lenz,V., \& Hall, D. (2000), Emotion Marketing: The Hallmark Way of Winning Customers For Life. McGraw-Hill: New York. Robinette, S. (2003). Emotion marketing. Telephony, (19), 40-41.

Teece, D. J. (2010). Business Models, Business Strategy and Innovation. Long Range Planning, 43(2-3), 172-194.

Weerdesteijn, J. M. W., Desmet, P. M. A., \& Gielen, M. A. 2005. Moving Design: To Design Emotion through Movement. The Design Journal 8(1), 28-40.

Wrigley, C. (2011). Visceral Hedonic Rhetoric. 1-224 Available at: http:// eprints.qut.edu.au/46040/ [Accessed March 24, 2013].

Wrigley, C. (2013). Design Dialogue: The Visceral Hedonic Rhetoric Framework. Design Issues, 29(2), 82-95.

Verhoef, P., Lemon, K., Parasuraman, A., Roggeveen, A., Tsiros, M., \& Schlesinger, L. A. (2009). Customer Experience Creation: Determinants, Dynamics and Management Strategies. Journal of Retailing, 85(1), 3141.

Zott, C., Amit, R., \& Massa, L. (2010). The Business Model: Theoretical Roots, Recent Developments, and Future Research (Working Paper). IESE Business School, University of Navarra.

\begin{abstract}
Abstrakt (in Polish)
Projektanci staja się świadomi znaczenia tworzenia silnych doznań emocjonalnych powiqzanych z nowymi produktami materialnymi w ostatnim dziesięcioleciu. Jednak, również ze strony firm, pojawiło się zwiększone zainteresowanie w opracowywaniu nowych usług i modeli biznesowych, jako uzupełniajqcych innowacyjnych form opartych na emocjach. To interdyscyplinarne badanie czerpie z nauk psychologicznych teorii emocji - i nauk o zarzqdzaniu - literatury modelu biznesowego do wprowadzenia nowego programu innowacyjnego. Termin VHR - retoryka dogłębnego hedonizmu jest zdefiniowany jako właściwości produktu (w tej pracy rozszerzenie usług i modelu biznesu), który przekonujqco skłania do dqżenia do przyjemności na instynktownym poziomie poznania. Ta praca stanowi podstawę dla VHR poza domyślnym środowiskiem produktu, prezentujq̨c wyniki badań empirycznych, które organizacje przeprowadziły badajqc możliwości zastosowania VHR w kontekście ich działalności. Stwierdzono, że firmy obecnie wierzq, że VHR jest postrzegane albo w ich produkcie i/ lub w usługach, które świadczq. W konsekwencji, sugeruje to przeniesienie perspektywy wokół korzystania z VHR w konstrukcji modelu biznesowego danej firmy, w celu wpływania na wyniki swoich produktów i / lub projektowania usług, co prowadzi do ogólnego silniejszego zwiq̨zu emocjonalnego z klientem.
\end{abstract}

Słowa kluczowe: VHR, projektowanie emocjonalne, innowacje biznesowe, tworzenia usług, projektowanie modelu biznesowego.

\title{
Biographical notes
}

Karla Straker is a graduate of Industrial Design at the Queensland University of Technology and is currently completing her PhD. Her research is cross- 
faculty, engaging with industry and academics across the fields of design, business and information systems. Karla's research is focused on working with companies to understanding customer emotions as a way to design engaging interactions via technology.

Dr Cara Wrigley is a senior lecturer in the field of Design-led Innovation (DLI). Building on her solid practical industry experience and combined with her scholarly expertise in emotional design, she is actively researching the value that design holds in business - specifically through the creation of strategies to design business models which lead to emotive customer engagement. She currently directs the Queensland University of Technology's DLI Research Lab, placing postgraduate researchers within Australian businesses. Cara has presented and published widely in the field of design-led innovation and currently leading several initiatives to contribute to both industry and academia on the value of design to business. 


\title{
Diaspora Business Model Innovation
}

\author{
Aki Harima ${ }^{1}$, Sivaram Vemuri ${ }^{2}$
}

\begin{abstract}
This paper explores how diasporans achieve business model innovation by using their unique resources. The hypothesis underlying the paper is that the unique backgrounds and resources of the diaspora businesses, due to different sources of information and experiences as well as multiple networks, contributes to business model innovation in a distinctive manner. We investigate the English school market in the Philippines which is established by East Asian diaspora who innovate a business model of conventional English schools. Two case studies were conducted with Japanese diaspora English schools. Their business is analyzed using a business model canvas (Osterwalder \& Pigneur, 2010) and contrasted with the conventional business model. The empirical cases show that diaspora businesses use knowledge about their country of origin and engage with country of residence and multiple networks in different locations and constellations to identify unique opportunities, leading to a business model innovation.
\end{abstract}

Keywords: business model canvas, east Asian diaspora, transnational entrepreneurship, opportunity recognition, mixed embeddedness.

\section{INTRODUCTION}

In line with the growing internationalization and transnationalization, the number of overall migrants has increased and the role of diasporans has attracted increasing attention from policy makers and researchers. Diasporans are migrants and their descendants who maintain homeland orientation (Safran, 1991). The impact of their business activities on the world economy has become important. When they move from a country to another, they transfer not only human capital, but they create flows of money (Gillespie et al., 1999; Nielsen \& Riddle, 2009; Riddle, 2008) and knowledge and technology (Saxenian, 2005; Kapur, 2001; Tung, 2008).

Businesses conducted by diaspora members are unique because of their resources characterized by mixed embeddedness in country of origin

\footnotetext{
1 Aki Harima, Research Assistant, University of Bremen, LEMEX Chair in Small Business \& Entrepreneurship, WilhelmHerbst-Str. 5, D-28359 Bremen, Germany, tel.: +49 421218 66876, e-mail: harima@uni-bremen.de 2 Dr. Sivaram Vermuri, Associate Professor of Economics, Charles Darwin University, 21 Kitchener Drive, Darwin NT 0801, Australia, tel.: +61 8 89468835, e-mail: ram.vemuri@cdu.edu.au.
} 
(COO) and country of residence (COR) (Kloostermann et al., 1999). Their main resources are diaspora networks (Dutia, 2012; Kuznetsov, 2006) and cognitive diversity which allows them to recognize unique business opportunities. For instance, Chinese diasporans historically establish their trading business through an intensive usage of Chinese transnational diaspora networks (Cohen, 2008; Cheung, 2004; Rauch \& Trindade, 2002). Knowing multiple cultural contexts, diasporans recognize business chances which are not recognized by local population. Turkish diasporans in Europe developed wellknown 'Döner Kebab', a fast food they modified for European customers (Wahlbeck, 2004). Indian diasporans identified a number of opportunities in IT industries in their COO (Chacko, 2007).

While the uniqueness of diaspora business and its innovativeness is still relatively unknown, there is a general perception that diaspora business is unique compared to the non-diaspora business. It is therefore important to understand and examine the reasons for this uniqueness. In this paper, we take a closer look at business models in order to investigate the innovativeness and novelty of diaspora businesses.

There are two main reasons for this investigation. First, business models describe not only firms per se, but also interrelations between firms and partners and value co-creation. Diasporans are known to have complex network dynamics due to their mixed embeddedness in host and home countries (Kloostermann et al., 1999). Diaspora networks (Dutia, 2012; Kuznetsov, 2006) are categorized as network resources. Observing their business model enables us to analyze the impact of such network dynamics on their business. Second, business models consist of different components of businesses, which enables us to focus on the impact of diaspora resources on each of components separately.

The aim of this paper is to address the following research questions: (i) How do diasporans innovate an existing business model? (ii) How do they use their diaspora resource for business model innovation? In order to answer these questions, we investigate the English language school industry in the Philippines, which is established by East Asian diasporans. They created a business model innovation (Chesbrough, 2010; Chesbrough \& Rosenbloom, 2002) in the English learning market for East Asians by establishing a new business model. This paper investigates their business model compared to the business model of conventional English schools by applying business model canvas (Osterwalder \& Pigneur, 2010) as an analytical tool. Two case studies with Japanese English schools in the Philippines as well as extensive secondary data analysis are conducted. This paper will contribute to explore the characteristics of diaspora businesses and the role of resources and embeddedness of entrepreneurs on business model innovation. 
This paper is structured as follows: First, previous findings on diaspora business and business model innovation are presented and the usage of business model canvas is introduced as an analytical tool for this study. Subsequently, research approach is described and justified followed by a brief introduction of the diaspora English school market in the Philippines. The brief background provides a context for conducting an analysis of the business models of two different types of English schools. This is followed by a discussion of how diaspora resources influence business model innovation. Finally, together with the summary of research results, contributions as well as limitations are presented.

\section{CONCEPTUAL BACKGROUND}

\section{Diaspora business}

Migration is a growing phenomenon. According to the International Migration Outlook from OECD (2013), there are 232 million people living outside their country of birth around the world in 2013, which represents 3.2 percent of the world's population. This number is expected to become 405 million by 2050 in the world (International Organization for Migration, 2014). The diaspora can be understood as a specific type of migrants and refers to migrants and their descendants who maintain a strong relationship with their $\mathrm{COO}$ and COR (Safran, 1991). These people are in a special constellation of being embedded in multiple cultures and societies of different countries (Drori et al., 2009). This multiple societal and cultural embeddedness is named as 'mixed embeddedness' by Kloostermann et al. (1999).

The diaspora population has gained an increasing attention from policy makers and researchers, assisted by the wave of transnationalism, globalization, and accelerated by rapid technological development in transportation and communication, which has reduced migrants' barriers of maintaining strong connection to home countries (Levitt, 2001; Tölölyan, 1996). Diasporans engage in business activities in a unique form due to their mixed embeddedness and transnational settings. Their business activities have unignorably significant impacts on the global economy. For instance, they send a substantial part of their earnings in COR to their home country in the form of remittance. The total remittance flow was projected to reach 434 billion USD (Worldbank, 2014:3) and diaspora remittance sometimes is an essential financial resource of developing countries. Their business activities, however, do not only have financial impacts on their $\mathrm{COO}$. In fact, they create different types of flows, by transferring knowledge, innovation, technology and institutions (Saxenian, 2005; Riddle \& Brinkerhoff, 2011). 
Despite its growing importance, the nature and characteristics of diaspora business is still not fully investigated. Previous scholars have attempted to investigate this phenomenon from a rather macro perspective including the impact of ethnic business on the local economy such as job creation and economic and cultural integration (Geddes, 2001; Zabin \& Hughes, 1995) or technological diffusion (Saxenian, 2005; Lodigiani, 2009; Hornung, 2014), for instance, through diaspora homeland investment (Gillespie et al., 1999; Kotabe et al., 2013; Nielsen \& Riddle, 2009). But we still know little about Diaspora business per se at the micro level. How does their business structure differ from non-diaspora business? Are there any novelties of diaspora businesses compared to non-diaspora businesses? Where are these differences come from? While a detail observation of Diaspora business is still a long way away, there are previous findings that may offer some hints for answering these questions.

Diaspora businesses exist when individuals in the diaspora create them. Diaspora businesses occur because of multiple forms of displacements. The first form of displacement arises from the place of birth resulting in movements from $\mathrm{COO}$ to COR. In certain circumstances the conditions in the COR create another form of displacement. It is the second form of displacement which arises from the general workforce and the response to this displacement is where the migrants search for connections elsewhere such as the one where migrants are attracted to business as they are not able to function in the mainstream economic activities of the COR. A third form of displacement occurs when diasporans in businesses at the COR become business diasporans in both $\mathrm{COO}$ and COR. The market conditions in the COR create an environment for opportunity seeking for building on connections elsewhere resulting in being attracted to familiar to familiar factors in COO. Diaporans become enablers of business operations, and market expansions. Thus businesses undergo triple transformations unlike the non-Diaspora businesses (Vemuri, 2015). As a result, diaspora business is an embodiment of continuous innovations and needs a closer examination to understand business innovations. There are differentiating features of emergent diaspora businesses that are primarily based on the experiences of individuals belonging to the diaspora such as pull, push, re-pull, and repush factors associated with migration (Vemuri, 2014). At one level, the displacement and reconnection to spaces through time is an essential reason for the existence of diaspora businesses. At another level, their nature of existence is due to discontinuity from the organic and endogenously evolving organizational skin. Therefore, diaspora businesses exist combining both business and diaspora features. 


\section{Business model and innovation}

A business model describes the way value is created within an organization by focusing on various components of firms' activities and their interrelations. A business model, therefore, becomes a frequently-used unit of analysis for researchers, warranting a need to understand a holistic overview of creation of total value. Recently business models have attracted much attention from both academicians and practitioners. According to the literature review by Zott et al. (2011), peer-reviewed academic journals published at least, 1,777 articles on business models have been published. In a similar vein, Ghaziani and Ventresca (2005) found 1,729 publications that referred to the term 'business model'.

One of the main explanation for the growing interest on business models is that a business model can create a new form of innovation, which possibly create more sustainable competitive advantages than other forms of innovation (Chesbrough, 2007). A business model innovation can be realized either by existing firms, which innovate or change their original business model, or by new entrants, which implement a new business model to the market. Business model requires simultaneous change to two or more elements of a business model to recreate and convey value in a novel way (Lindgardt et al., 2009). According to Bucherer et al. (2012), there are two main reasons why business model innovations create competitive advantages. First, it takes considerable time and resource investment for simultaneously changing different elements. For instance, when a firm innovates solely an existing product such as application of new technology to a digital camera or smartphones, competitors imitate with relative ease, because firms do not have to change their entire business model. However, when a business model itself is innovated like IKEA, the Swedish furniture company which innovated different components of business models of the conventional furniture retailers including value propositions, customer segments, customer channels, it is more challenging for existing furniture retailers, as they have to change many of their business components at the same time. Second, the new business model should suit all facets of the company including longterm corporate strategy, corporate culture as well as core competencies of the firm. Using the example of IKEA, imitating IKEA's business model is almost impossible when furniture retailers focus on luxurious customer segments, have traditional corporate cultures, or rely strongly on long-standing partners over generations who have developed routines and practices, and become reticent to fundamentally change their business model.

In either case, a precursor to business model innovation by firms is their need for tools to assess their current business model or dominant business model in the market in order to create new ones. While there are a number 
of tools with different components developed by various scholars (c.f. Morris et al. 2005), one of the most famous and detailed analytical tool is the business model canvas (Osterwalder \& Pigneur, 2010). It allows companies to actively create and assess new or already existing business models (Pavie et al., 2013). Business model canvas consists of nine interrelated components: (1) customer segments, (2) value propositions, (3) channels, (4) customer relationships, (5) key activities, (6) key resources, (7) key partners, (8) revenue streams, and (9) cost structure. This analytical tool has an advantage of simultaneously visualizing many factors and their interrelations.

\section{Diaspora business model innovation}

Diaspora businesses are unique. In some cases, this uniqueness is because of the nature of the business model innovation undertaken by the diaporans. Which role does diaspora play in creating an innovative business model? In this section, we discuss the possible role of diaspora in business model innovation. In the context of this paper, we consider diaspora business model innovation to occur when diasporans simultaneously change more than two components of existing business models in a novel way, following the definition by Lindgardt et al. (2009).

As discussed above, diasporans are characterized by their mixed embeddedness in different country contexts (Kloostermann et al., 1999). We suggest that mixed embeddedness enables diasporans perceiving unique opportunity, which then leads to business model innovation. Ardichvil et al. (2003) provide a framework of opportunity identification by arguing that beside personality traits, prior knowledge and social networks influence entrepreneurial alertness. Entrepreneurial alertness is defined as 'a propensity to notice and be sensitive to information about objects, incidents, and patterns of behaviors in the environment, with special sensitivity to maker and user problems, unmet needs and interests, and novel combinations of resources' (Ray \& Cardozo, 1996). The higher alertness increases the likelihood of an opportunity for being recognized. Diasporans' experiences, accumulated knowledge and network capital are assumed to be positively related to unique opportunity recognition.

How can diasporans' mixed embeddedness leads to unique business opportunity recognition? First, through being embedded in two or more different country contexts, diasporans accumulate diversified knowledge based on first hand exposures and experiences of both countries. Prior knowledge can be industry knowledge such as knowledge of markets, customer problems and ways to serve customers (Ardichvili et al., 2003; Shane, 2000; Baron, 2006; Hoang \& Antoncic, 2003). Diaspora population is assumed to have profound 
knowledge about markets and customers of COR and COO. Knowing different markets and customer problems and characteristics of two countries are assumed to increase entrepreneurial alertness, and therefore enable them to recognize unique business opportunity which is otherwise overlooked by local population. This can lead them to innovate different components of their business model. As diasporans know markets of both $\mathrm{COO}$ and COR, they could, for instance, choose their customer segments from COO or COR, or both. In a sense, they have a larger base and variety to select from. They could also reflect their knowledge about customer problems and ways to serve customers of $\mathrm{COO}$ and $\mathrm{COR}$ on customer relationships, value proposition and channels. They are assumed to be able to change an existing business model in COR, which targets at customers in COR, into a new business model in COR, which targest at customers in $\mathrm{COO}$, or other way around.

Second, business activities of diasporans are also characterized by their unique network dynamics. Especially, the so-called 'diaspora network', which describes their network with co-ethnics in $\mathrm{COO}, \mathrm{COR}$ and other countries, has attracted considerable research attention as one of the most unique part of their network dynamics (Dutia, 2012; Meyer \& Wallaux, 2006; Kurnetsov, 2006; Elo, 2014). Diaspora network is known as a source of labor (Damm, 2009) as well as customers (Bowles \& Herbert, 2004; Anthias, 2007) for diaspora businesses. Harima (2014) also argued that a diaspora network offers various benefits such as acquisition of external resources and sustaining motivation. Having a network not only with the local population, but also with co-ethnics living in different countries is assumed to be positively related to entrepreneurial alertness. Such networks can offer key partners or key resources. Diasporans can choose their business partners from different networks. They can be someone from $\mathrm{COO}$ or COR, or even somewhere else, where co-ethnics are living. As diaspora networks often offer labors, diaspora may have different human resource bases to draw from than Non-Diaspora business.

To sum up, diasporans' mixed embeddedness allows them to innovate different components of business models in unconventional ways, as they can identify unique business opportunities which are overlooked by local population in COR. We suggest that diasporans' knowledge of customers and markets, factor markets in particular, in COO and COR impacting on their to network dynamics to such an extent that they allow them to identify opportunities to innovate an exisiting business model.

\section{RESEARCH METHODS}

The aim of this study is to answer the following research questions: (i) How do diasporans innovate an existing business model? (ii) How do they use 
their diaspora resources for business model innovation? In order to answer these questions, we chose the English school industry in the Philippines. This industry was established by the East Asian diaspora, who innovated a business model of conventional English schools for non-native English learners. These English schools in the Philippines are established mostly by South Korean or Japanese diasporans and targeted at their co-ethnic customers who visit the Philippines to learn English. They employ and train Filipino English teachers.

Two case studies were conducted with the Japanese Diaspora English schools ('School A' \& 'School B') in the Philippines. We chose a case study approach design, as it should be considered to answer "how" questions according to Yin (2003). She also pointed out that a case study approach can cover contextual factors which are relevant to the phenomenon. As diasporans' unique constellation is a central focus of this study, this approach is chosen. Unit of analysis is the individual diaspora entrepreneurs who reflect their diaspora resource on business model components. In order to explore how diasporans innovated a business model of conventional English schools in Western English speaking countries, their business models are also investigated. For the sake of simplification, we call the English schools in the Philippines ran by East Asian diaspora as "diaspora English school" and the other "conventional English school" in this paper.

Within the scope of the case studies, the main data is in-depth interviews with Japanese founders. In-depth interviews took $60-180$ minutes and were conducted in Japanese. Additionally, a number of casual conversations were conducted with Japanese employees, Filipino management employees, Filipino teachers and Japanese customers on the location. In April 2015, one of the authors stayed three days at the School A and one day at the School B, which allowed her ethnographical observation (Tedlock, 1991). Memos taken during the observation as well as company websites are used for data triangulation (Denzin, 1970). As for Conventional English Schools, we gathered secondary data including official websites, web reputation as well as brochure of five English schools in USA, Canada, UK, Australia and New Zealand. The summary of data collected is described in Table 1.

We selected these two schools, since School A is a pioneer and one of the first English schools established by Japanese diasporans in the Philippines, and School B is a late-comer. Taking a closer look at these two schools allows us to consider variations caused by market entry timing. We selected five conventional English schools in five Western English speaking countries, which are main destinations of East Asian English learners, based on the popularity according to agents. 
Table 1. Summary of primary data

\begin{tabular}{|c|c|c|c|c|c|c|}
\hline & $\begin{array}{l}\text { Interview } \\
\text { partner }\end{array}$ & Style & $\begin{array}{l}\text { Type of Inter- } \\
\text { action }\end{array}$ & $\begin{array}{l}\text { Duration } \\
\text { (min.) }\end{array}$ & Language & Data \\
\hline \multirow{16}{*}{$\begin{array}{c}\text { School } \\
\text { A }\end{array}$} & $\begin{array}{l}\text { Japanese } \\
\text { founder }\end{array}$ & Skype & Interview & 120 & Japanese & $\begin{array}{l}\text { Recorded and } \\
\text { transcribed }\end{array}$ \\
\hline & $\begin{array}{l}\text { Japanese } \\
\text { founder }\end{array}$ & Skype & Interview & 80 & Japanese & $\begin{array}{l}\text { Recorded and } \\
\text { transcribed }\end{array}$ \\
\hline & $\begin{array}{l}\text { Japanese } \\
\text { founder }\end{array}$ & Face-to-face & Conversation & 240 & Japanese & $\begin{array}{l}\text { Interview } \\
\text { memo }\end{array}$ \\
\hline & $\begin{array}{l}\text { Japanese } \\
\text { employee A }\end{array}$ & Face-to-face & Conversation & 60 & Japanese & $\begin{array}{l}\text { Interview } \\
\text { memo }\end{array}$ \\
\hline & $\begin{array}{l}\text { Japanese } \\
\text { employee B }\end{array}$ & Face-to-face & Conversation & 10 & Japanese & $\begin{array}{l}\text { Interview } \\
\text { memo }\end{array}$ \\
\hline & $\begin{array}{l}\text { Japanese } \\
\text { employee C }\end{array}$ & Face-to-face & Conversation & 10 & Japanese & $\begin{array}{l}\text { Interview } \\
\text { memo }\end{array}$ \\
\hline & $\begin{array}{l}\text { Japanese } \\
\text { employee D }\end{array}$ & Face-to-face & Conversation & 10 & Japanese & $\begin{array}{l}\text { Interview } \\
\text { memo }\end{array}$ \\
\hline & $\begin{array}{l}\text { Japanese } \\
\text { emplovee E }\end{array}$ & Face-to-face & Conversation & 10 & Japanese & $\begin{array}{l}\text { Interview } \\
\text { memo }\end{array}$ \\
\hline & $\begin{array}{l}\text { Filipino } \\
\text { teacher A }\end{array}$ & Face-to-face & Conversation & 25 & English & $\begin{array}{l}\text { Interview } \\
\text { memo }\end{array}$ \\
\hline & $\begin{array}{l}\text { Filipino } \\
\text { teacher B }\end{array}$ & Face-to-face & Conversation & 25 & English & $\begin{array}{l}\text { Interview } \\
\text { memo }\end{array}$ \\
\hline & $\begin{array}{l}\text { Filipino } \\
\text { teacher C }\end{array}$ & Face-to-face & Conversation & 10 & English & $\begin{array}{l}\text { Interview } \\
\text { memo }\end{array}$ \\
\hline & $\begin{array}{l}\text { Filipino } \\
\text { teacher D }\end{array}$ & Face-to-face & Conversation & 20 & English & $\begin{array}{l}\text { Interview } \\
\text { memo }\end{array}$ \\
\hline & $\begin{array}{l}\text { Filipino } \\
\text { teacher E }\end{array}$ & Face-to-face & Conversation & 15 & English & $\begin{array}{l}\text { Interview } \\
\text { memo }\end{array}$ \\
\hline & $\begin{array}{l}\text { Japanese } \\
\text { customer A }\end{array}$ & Face-to-face & Conversation & 180 & Japanese & $\begin{array}{l}\text { Interview } \\
\text { memo }\end{array}$ \\
\hline & $\begin{array}{l}\text { Japanese } \\
\text { customer B }\end{array}$ & Face-to-face & Conversation & 60 & Japanese & $\begin{array}{l}\text { Interview } \\
\text { memo }\end{array}$ \\
\hline & $\begin{array}{l}\text { Japanese } \\
\text { customer C }\end{array}$ & Face-to-face & Conversation & 60 & Japanese & $\begin{array}{l}\text { Interview } \\
\text { memo }\end{array}$ \\
\hline \multirow{7}{*}{$\begin{array}{c}\text { School } \\
\text { B }\end{array}$} & $\begin{array}{l}\text { Japanese } \\
\text { founder A }\end{array}$ & Skype & Interview & 70 & Japanese & $\begin{array}{l}\text { Recorded and } \\
\text { transcribed }\end{array}$ \\
\hline & $\begin{array}{l}\text { Japanese } \\
\text { manager }\end{array}$ & Skype & Interview & 60 & Japanese & $\begin{array}{l}\text { Recorded and } \\
\text { transcribed }\end{array}$ \\
\hline & Filipino & Face-to-face & Interview & 70 & English & Recorded and \\
\hline & director & & & & & transcribed \\
\hline & $\begin{array}{l}\text { Japanese } \\
\text { director }\end{array}$ & Face-to-face & Conversation & 60 & Japanese & $\begin{array}{l}\text { Interview } \\
\text { memo }\end{array}$ \\
\hline & $\begin{array}{l}\text { Filipino } \\
\text { manager }\end{array}$ & Face-to-face & Conversation & 40 & English & $\begin{array}{l}\text { Interview } \\
\text { memo }\end{array}$ \\
\hline & $\begin{array}{l}\text { Filipino } \\
\text { teacher }\end{array}$ & Face-to-face & Conversation & 5 & English & $\begin{array}{l}\text { Interview } \\
\text { memo }\end{array}$ \\
\hline
\end{tabular}

Gathered information and data through above mentioned methods are analyzed in a descriptive manner. As an analytical tool, business model canvas (Osterwalder \& Pigneur, 2010) is used, which helps us to visualize business models of diaspora English schools and conventional English schools. 


\section{English language market in the Philippines}

Being a past colony of the United States, the Philippines has the fifth largest English-speaking communities by population in the world. According to Census 2000, there were 45.9 million English speakers, which represents $63.7 \%$ of the entire population of the country. Based on this fact, the country has attracted foreign investment employing low-cost English speaking Filipino staff. Since the late 1990s, a number of American firms started outsourcing telephone-based customer services to Filipino professionals (Friginal, 2007). Shortly after, South Korean firms opened up a language business in the Philippines and followed by the Japanese. While the exact number of such schools is unknown, the widely used number of such East Asian English schools in the Philippines is between 300 and 500 . The industry has steadily grown over the last years. According to the Department of Tourism in the Philippines (2003; 2013), from 70,000 to 100,000 foreign people visit the country as English language students annually. The country became one of the major destinations for South Korean and Japanese people who want to learn English abroad instead of Western English speaking countries. This emergent market represents the case in which diasporans created a new market through business model innovation. Next, we will analyze business models of such diaspora English schools and contrast them with conventional English schools.

\section{BUSINESS MODEL CANVAS}

In order to investigate how diasporans innovated an existing business model, we first briefly analyze nine components - (1) customer segments, (2) value propositions, (3) customer relationships, (4) channels, (5) revenue streams, (6) key activities, (7) key resources, (8) key partners, and (9) cost structures - of business model canvas of conventional English schools based on the secondary data. This will be followed by an analysis of the business models of diaspora English schools in the Philippines.

\section{Conventional English schools}

1) Customer Segments: Customer segments can be described with the following four dimensions: (i) nationality, (ii) age, (iii) purpose of visit, and (iv) duration of visit. First, these schools do not target at specific nationalities, but at every non-native English learners. Second, they mainly target at the people older than $16-18$ years old and do not commonly offer any special courses for children. Third, customers of conventional English schools have the following purposes of visit: (a) Exam preparation such as TOEFL, IELTS and TOEIC ${ }^{3}$; (b) Improvement

3 TOEFL (Test of English as a Foreign Language), IELTS(International English Language Testing System), and TOEIC (Test of English for International Communication) 
of conversational English, (c) improvement of business English. Fourth, these schools target mostly at long-stay students for one to twelve months. Based on this information, the typical customer segments of conventional English schools can be described as follows: (1) Non-native English speakers who want to prepare for English exams, (2) Non-native English speakers who want to improve their English conversational skills, and (3) Business personals who want to improve their business English.

2) Value Propositions: They have value propositions for each of three customer segments respectively: (1) Improve customers' English skills for reaching a high score at English exams with the support of qualified native English teachers; (2) Improve customers' English conversational skills with the support of qualified native English teachers; and (3) Improve customers' business English skills with the support of qualified native English teachers.

3) Customer Relationships: Local staffs take care of them during their stay by giving them personal advice and finding temporary accommodation, organizing social activities as well as vocational opportunities (e.g. internship) with costs. Some schools have staffs who are able to speak the language of the dominant student groups such as Chinese, Japanese, and Spanish.

4) Channels: They reach their potential customers mainly through Internet websites/advertisement as well as through broker agents in different countries.

5) Revenue Stream: It consists of a registration fee, organizational fee and course fee. While the price varies between countries and cities, a student, for instance, would pay ca. 2,200 USD for 20 hours of English lessons for four weeks in a large city in Canada excluding accommodation fee.

6) Key Activities: Conventional English schools have two main activities. The first activity is offering different types of English lessons/courses. These courses are oriented mainly towards groups. In order to ensure the quality of lessons, training teachers, controlling and improving lessons are included in key activities as well. The second activity is organizing accommodation, social activities and internships.

7) Key Resources: In order to conduct the above-mentioned key activities, these schools have qualified native English teachers and original curriculum to satisfy customers' needs.

8) Key Partners: They have partnerships with broker agents in different countries, tourism offices, real estate companies, local firms, local host families, and universities/colleges in their country and abroad.

9) Cost structures: Considering the eight components above, they have the following costs: salaries of teachers and local staffs, facilities costs as well as marketing cost which they usually pay to brokers. These costs are considered to be high, as conventional English schools are located in 
developed countries with a high living standard. The business model of Conventional English Schools is depicted in Figure 1.

Philippines, we analyze a business model of diaspora English schools with the help of business model canvas. School A was established in 2010 by a Japanese founder together with a Filipino co-founder in San Manuel. Since the establishment, this school has been successfully operating its language business and more than 2,000 students have learned at the school. This school has become one of the largest employers in the region. School B is a part of a large group established by Japanese founder. He started his business activities in the Philippines in 1989. Starting with trading business, he has continuously expanded his business to manufacturing, manpower supply, health service; his group has currently twelve companies in the Philippines and in Japan. He started his language business in 2005 by offering Japanese language course for Filipinos and then offering English online to Japanese customers. His English schools is established in 2015 in Manila and starts offering English school service for Japanese customers. Both of the schools have more than 20 full-time English teachers.

\section{Diaspora English schools in the Philippines}

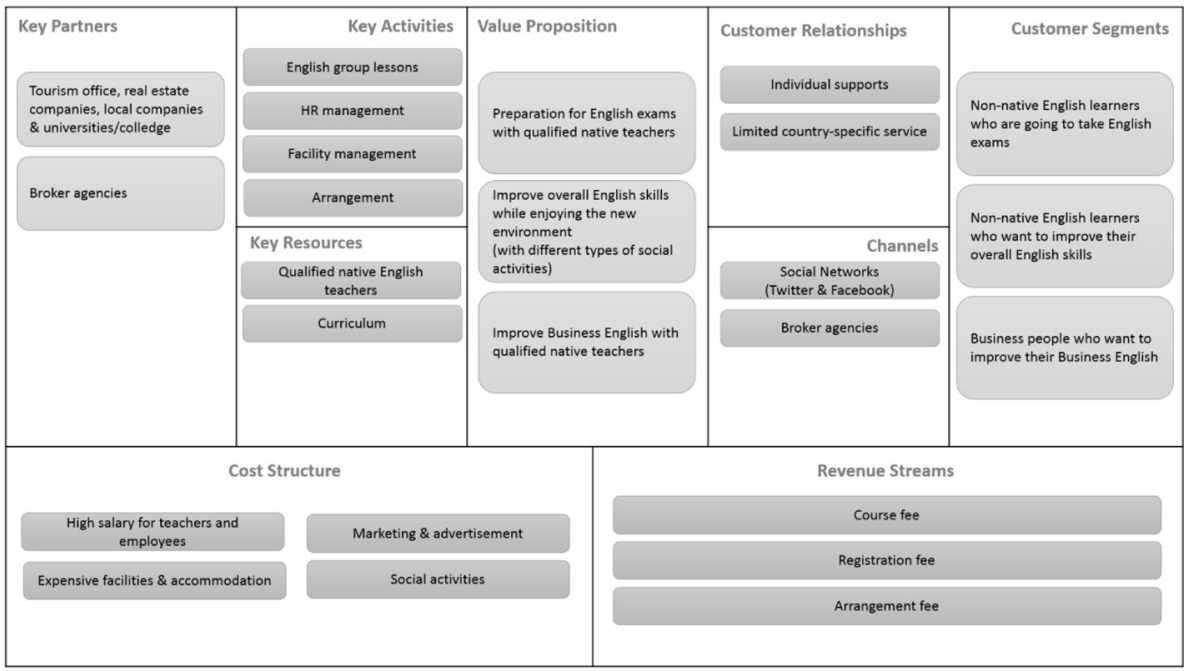

Figure 1. The business model of Conventional English Schools 
1) Customer Segments: Analyzing the same four dimensions as conventional English schools, (i) nationality, (ii) age, (iii) purpose of the visit, and (iv) duration of the visit, we confirmed that Diaspora English Schools are more specific in every dimension. First, these schools generally focus on the customers with the same country of origin as school owners. According to the founder of School A, "...(our customers are) mostly Japanese. More than $90 \%$ are Japanese and the others are Korean." The manager of the School B also indicates that this school targets only at Japanese customers and does not have any intention to target at other nationalities. The reason for this clear customer segmentation is explained by the founder of School A as follows: "Japanese customers have special demands which cannot be fulfilled by Korean schools. We offer breakfast, lunch and dinner for our customers. We can offer meals which are preferred by Japanese customers. Korean customers eat very spicy food every day, but Japanese not. Korean customers prefer strict and a sort of military style rules at schools, Japanese want to learn English also in an intensive manner, but rules and curriculums should not be as tough as Korean schools. Japanese customers are very shy, we need to train our Filipino teachers to understand characteristics of Japanese customers. We can offer service and staff support which exactly match their expectation, as we understand their unique demand."

Second, diaspora English schools target at different age groups. While the main target is university students and young professionals who want to improve their English for their career, School A also targets at children up to twelve years old as well as senior people. The case of School A shows that the founder's awareness of Japanese culture and society was essential for this customer segmentations: "University students have much time in Japan but do not have much money. They could but afford learning English in the Philippines because it is much cheaper than in USA or Australia. Business people are sent by companies, who are not happy with long absence of their employees. They want their employees to learn English as quick as possible, like one or two weeks. Curriculums of conventional English schools are oriented at people who want to stay for a longer term and therefore they do not have an extremely intensive course. At our schools, they can take lessons more than nine hours a day. After the lessons, we have enough rooms for them to study alone. For children, parents want them to go abroad at the early stage, but they don't want them to travel far away. The Philippines is still closer to Japan than other Western English speaking countries. Travelling to the Philippines is easier due to short flight hours and only one hour of time difference between the two countries. Moreover, Japanese parents want to send their children to schools where Japanese staffs are working. Senior people have a sort of similar situations. They do not prefer to take a long flight to Australia or to USA, UK. They also prefer nice tropical weather and customer supports by 
Japanese staffs." School B, in contrast, is not fully sure with its target group. The manager of School B explains the strategy of school as follows. "Well, we are targeting at business people who have enough money, because we offer high-quality service. Therefore, we do not offer apartments but business hotels as accommodation. Maybe we also target at university students and senior people who have enough money."

Third, these schools also focus on the customer segments whose purpose of visit is to learn conversational English. Due to the inefficient education system overemphasizing on written exams, inactive student participation during the class and cultural differences (for instance, Japanese students are ashamed of making grammatical mistakes in front of others), South Korean and Japanese people have extreme difficulty in communicating in English (Dougil, 2008). Both School A and School B are aware of communication problems of Japanese customers and structure their program to minimize them.

Fourth, both School A and School B mainly target at people who intend to stay abroad for a short time, because they are aware that Japanese customers are not able to leave their country for a long time. Japanese students are under the pressure of 'simultaneous recruiting system' (Amin, 2012), which refers to the custom that companies hire new graduates all at once and employ them during the third of four years of bachelor studies, and Japanese employees take only 10 work days off annually (Ray et al., 2013).

Considering the points described above, diaspora English schools target at the following customer segments: (1) Young Japanese students and career changers who want to improve English within the relatively short time by focusing on conversational English; (2) Japanese firms who want to improve English skills of their employees within the limited budget and time; (3) Japanese parents who want to let their children improve their English skills; (4) Japanese retirees who want to improve their English conversational skills.

2) Value Propositions: For each of four customer segments, diaspora English schools have value propositions: (i) Learn how to communicate in English intensively within the short term at an affordable price; (ii) Improve employee's English skills within the short term at low budget; (iii) Improve children's English skills in a secure environment; (iv) Learn English in a secure and comfortable environment. One of the characteristics of diaspora English schools is that they offer one-to-one lessons. The founder of School A recalled his own experience in learning English in USA and said, "I think almost all of the Japanese have the same problem as I had in the United States, when I was a language student. You pay much money for English group lessons and attend them to end up speaking just one sentence during 4 hours of class. Japanese people 
are very shy. Even though they have a better grammatical understanding than European people, European students speak much more, because their mother tongue is similar to English and their education system focuses also on communication unlike in Japan. I thought, one-to-one lessons are the only way for Japanese to improve English."

3) Customer Relationships: School A has a very close relationship with customers, as the founder, all of the Japanese staffs and most of Filipino English teachers live together on the same campus. School B has more distance from customers, but Japanese staffs both in Japan and in the Philippines can take care of their customers before and during their stay.

4) Channels: School A uses Internet websites as well as social networks such as Twitter and Facebook as channels to reach their customers. School B does direct marketing to their customers of Online English schools. School B has offered Online English schools in the final years and they have a large pool of customers. While there are also seminars and exhibitions for English schools in the Philippines, both of them did not use such external agents.

5) Revenue Streams: Similar to conventional English schools, the main revenue stream of diaspora English schools is the course fee. The noticeable difference is that the course fee often includes accommodation fee and meals at diaspora English schools. For example, the lowest price at School A for one week is 264 USD $^{4}$ with 20 hours of one-to-one lessons, five hours of group lessons, meals (breakfast, lunch, and dinner), as well as accommodation in a shared room with four people. Depending on room types and hours of lessons, this price varies. Even with the fee for accommodation and meals, the price is significantly cheaper than Conventional English Schools.

6) Key Activities: Similar to conventional English schools, their key activity is offering English lessons/courses. While conventional schools mainly offer group lessons, diaspora English schools offer almost exclusively one-toone English lessons. Additionally, they also manage accommodation, facilities for students and employees as well as social activities. School A has also special rooms for customers to learn English after lessons until midnight. The founder of the School A explained that "Japanese customers are used to the 'Jisyushitsu (自習室) ) $^{5}$-culture. Since they have to learn a lot for cram schools, for university entry exams and so on." In fact, these rooms were all booked until midnight when one of the authors visited the school. It shows that this facility fulfills customers' unique demands. School B also facilitates access to a room with electronic devices which allow students to practice English pronunciation. The local Filipino director of School B explains, "Japanese people have difficulties to pronounce English, as there are not many English teachers who can

4 Calculated 1 USD=123JPY, round off after the decimal point (20 June 2015).

5 Jisyushitsu(自習室) is a room where students can learn by themselves. Educational institutions such as schools, universities and cram schools in Japan facilitate such rooms for their students. 
do that in Japan. Therefore, we developed this room, as we focus on conversational English."

7) Key Resources: In order to conduct the above mentioned activities, diaspora English schools are required to orchestrate local resources and diaspora resources. It is essential for them to successfully train Filipino English teachers to be able to understand the demand and characteristics of Japanese customers. "We trained our English teachers to be able to understand problems and difficulties of Japanese customers. (...) frequently we ask our students and teachers which problems they face in order to continuously improve our service. We should understand both Japanese customers and characteristics and culture of Filipino English teachers." (School A's founder). It is a complex task to train people from different cultural backgrounds, as founders and managers are required to have deep understanding of both cultures and successfully combine them. Their own understanding and awareness of Japanese society and culture is also related to customer satisfactions.

8) Key Partners: Diaspora English schools have a partnership with Japanese corporate customers and Japanese universities. They also collaborate with some local firms such as tourism office, transportation firms and hotels. School A has also a number of partnerships with Japanese companies in different countries of South East Asia. As some of Japanese students are interested in starting their career abroad after improving their English at Diaspora English schools, school A introduced students to these firms. In this case, Japanese diaspora network within South East Asian countries plays an important role.

9) Cost Structure: In the case of diaspora English schools, the following costs: salary for Filipino English teachers, local employees and Japanese staffs account for a large part of their cost structure. Compared to conventional English schools, however, the salary for English teachers and local staff is considerably low, as the average salary in the Philippines is lower than the other Western English speaking countries. According to the International Labor Organization (2009), the monthly average wage in purchasing power parity dollars in the Philippines is 279 USD. Filipino English teachers earn more than the average and have more support from Japanese employers in both cases. The cost for facilities such as school buildings as well as accommodation is also a major cost component. The business model canvas of diaspora English schools is depicted in the Figure 2. 


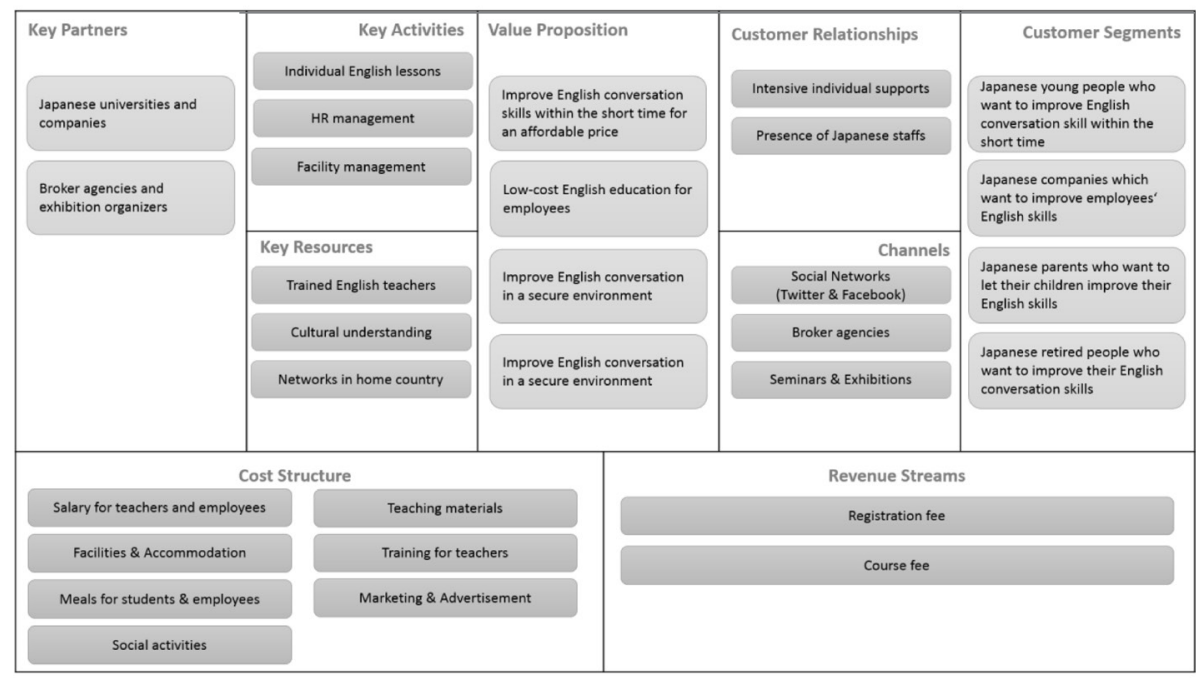

Figure 2. The business model canvas of diaspora English schools

\section{Discussion}

The above depicted business model canvas clearly show that a business model innovation took place in the English School market in Philippines. While all of the nine components of business model canvas of the conventional English schools were changed to a certain extent, the East Asian Diaspora innovated mainly five components in a novel way: (i) customer segments; (ii) value propositions; (iii) key resources; (iv) key partners; and (v) cost structures.

First, diaspora English Schools target at customers from their COO and segmentzed them into four groups to fulfill their unique demands. This customer segmentation is reflected on their value propositions. These schools consider specific demands and expectations of each of customer segments to develop their value propositions. As for key resources of diaspora English schools, they are required to orchestrate their COO-resources and CORresources by training Filipino English teachers to offer service which fulfill needs specific to Japanese customers. In a similar vein, diaspora English schools have a partnership with organizations both in $\mathrm{COO}$ and COR. At last, they add more values such as accommodations, meals or individual lessons by reducing cost for English teachers.

In the section of 'Diaspora Business Model Innovation', we discuss our assumption that diasporans' mixed embeddedness may positively influence their unique opportunity recognition, because they have knowledge about customers and markets in both $\mathrm{COO}$ and COR as well as country specific 
network dynamics. Following, we analyze how the mixed embeddedness influence the business model innovation by East Asian diasporans in the Philippines by contrasting two Business Model Canvases (Figure $1 \& 2$ ).

First, both of the cases vividly show the significance of knowledge about $\mathrm{COO}$ and COR. In case of School A, the founder uses his knowledge of Japanese society, job market as well as customer demands to identify unique customer segments and develop value propositions. It was his initial entrepreneurial motivation to solve the problem that Japanese cannot learn English effectively at Conventional English Schools despite of their large investment because of their shyness and Japanese English education which overemphasizes English grammar. He combined this knowledge into his knowledge about COR, as he also knew that what Philippines can offer for his business idea. In School B's case, School B was forced to segmentalize customers, as School B is a follower. Although School B's entrepreneur has more than 30 years of experience in the Philippines, he was new to the English School industry, which was already fully established with 300-500 diaspora English Schools. In order to avoid the fierce competition, School B decided to focus on the luxury segment. The entrepreneur's knowledge about the Philippines and Japan help the School B to offer luxurious service to Japanese business customers.

The knowledge about culture and society of COO and COR was also essential for the key resources of diaspora English schools. Their key resource is trained Filipino English teachers. In order to train Filipino English teachers to be able to understand Japanese customers' demand, they need to understand the culture and society of both countries.

How did their unique network dynamics influence opportunity recognitions to innovate an existing business model of conventional English schools? Figure 2 indicates that diaspora Business schools leverage different networks for their key partnership. Their customers, agents, staffs are Japanese, while other local staffs, English teachers, and some of their business partners are Filipino. They also have some partnerships with Japanese firms and universities in Japan whose employees/students visit schools to learn English. In case of School A, the school has also a broad diaspora network with Japanese firms in different countries in South East Asia who are interested in hiring Japanese students. In fact, many of alumni started working for these companies after leaving School A.

As for cost structure, mixed embeddedness did not play any significant role in terms of opportunity recognition. Using a low-cost labor in developing/ emerging countries for the benefit of own business is common also for companies from developed countries and is not specific to diaspora business.

In conclusion, our empirical cases show how East Asian diasporans leverage their mixed embeddedness to identify unique opportunities which 
lead them to innovate a conventional business model. Not only knowing contexts and markets of $\mathrm{COO}$ and COR, but also how they combine and orchestrate their knowledge to identify unique customer segments and develop value propositions as well as key resources. They also use different types of networks in $\mathrm{COO}$ and $\mathrm{COR}$, and diaspora networks even in other countries as key partners for their business model.

\section{CONCLUSION}

This paper explores how diasporans innovate an existing business model, and how they use their diaspora resources for business model innovation. In order to answer these questions, we take a closer look at the English school industry in the Philippines, where East Asian diasporans achieved a business model innovation. Thereby, we focus on their mixed embeddedness and its impact on unique opportunity recognition. Through conducting the two case studies with Japanese diaspora English schools, we developed business model canvases (Osterwalder \& Pigneur, 2010) of Diaspora English Schools and Conventional English Schools to investigate how diasporans innovated which components, and in which way. The findings show that East Asian diasporans changed mainly five out of nine components: (i) customer segments; (ii) value propositions; (iii) key resources; (iv) key partners; and (v) cost structures. Diasporans' mix embeddedness allows them to develop knowledge about $\mathrm{COO}$ and $\mathrm{COR}$ as well as complex network dynamics in different countries. These knowledge and networks allow them to recognize unique opportunities to innovate a conventional business model.

This paper has a few limitations. First, although two insightful case studies of Japanese English schools give us profound insights of Diaspora English Schools, more case studies should be conducted for providing a comprehensive understanding of the industry. For instance, both School A and School B did not have any significant networks with other diaspora English schools or broker agents. Therefore, we could not observe horizontal relationship between numerous diaspora English schools in the Philippines. Second, our analysis is based on one specific market and one specific diaspora. Therefore, this paper could not consider industrial and country variations. Third, while we use business model canvas as an analytical tool, we should be aware of its limitation. For instance, Coes (2014) point out some limitations of business model canvas including missing competitiveness, time elements and social values.

Despite these limitations, this study makes some contributions: First, the role of diaspora in business model innovation was explored by investigating how diasporans use their resources which are a result of mixed 
embeddedness due to unique opportunities available to them. Diasporans are no longer considered as helpless individuals with limited opportunities. On the contrary individuals being diasporans have expanded opportunities. Second, this study sheds a spotlight on diasporans from developed countries in emerging countries. Since current discussions on diaspora business and entrepreneurship overemphasis on diasporans from developing/emerging countries in developed countries, their business activities give a new insight into the research on diaspora business and entrepreneurship. Third, this paper has also a methodological contribution, showing a business model to be an effective analytical tool for investigating diaspora businesses. Fourth, this research makes a contribution to the business model literature by considering transnational dimensions in the context of business innovation.

Considering the limitations of our study above, we suggest that future research is needed to investigate the role of diaspora in the other country contexts. Moreover, their role in each of stages of firm's development must be studied. We suggest a use of longitudinal analysis as a meaningful way forward to analyze the role of diasporas for business model transformations overtime.

\section{References}

Amin, H. (2012). Japanese Shinsotsu recruitment culture. Retrieved from http://www.disc.co.jp/en/resource/pdf/SHINSOTSUCulture.pdf (Accessed on 10th of March, 2015).

Anthias, F. (2007). Ethnic ties: Social capital and the question of mobilisability. The Sociological Review, 55(4), 788-805.

Ardichvili, A., Cardozo, R., \& Ray S. (2003). A theory of entrepreneurial opportunity identification and development. Journal of Business Venturing, 18(1), 105-123.

Baron, R. A. (2008). Opportunity recognition as pattern recognition: How entrepreneurs "Connect the dots" to identify new business opportunities. The Academy of Management Perspectives, 20(1), 104-119.

Bowles, S., \& Gintis, H. (2004). Persistent parochialism: Trust and exclusion in ethnic networks. Journal of Economic Behavior \& Organization, 55(1), 1-23.

Bucherer, E., Uli E., \& Oliver G. (2012). Towards systematic business model innovation: lessons from product innovation management. Creativity and Innovation Management, 21(2), 183-198.

Chacko, E. (2007). From brain drain to brain gain: reverse migration to Bangalore and Hyderabad, India's globalizing high tech cities. Geo Journal, 68(2-3), 131-140. 
Cheung, G. C. K. (2004). Chinese Diaspora as a virtual nation: interactive roles between economic and social capital, Political studies, 52(4), 664-684.

Chesbrough, H. (2007). Business model innovation: it's not just about technology anymore. Strategy \& Leadership, 35(6), 12-17.

Chesbrough, H. (2010). Business model innovation: opportunities and barriers. Long Range Planning, 43(2-3), 354-363.

Chesbrough, H., \& Rosenbloom, R. S. (2002). The role of the business model in capturing value from innovation: evidence from Xerox Corporation's technology spin-off companies. Industrial and Corporate Change, 11(3), 529-555.

Coes, B. (2014). Critically assessing the strengths and limitations of the business model canvas. Master thesis business administration at the University of Twente. Retrieved from http://essay.utwente.nl/64749/1/ Coes_MA_MB.pdf, (Accessed on 18th of June, 2015)

Damm, A. P. (2009). Ethnic enclaves and immigrant labor market outcomes: Quasi-experimental evidence. Journal of Labor Economics, 27(2), 281314.

Denzin, N. (1970). The Research Act in Sociology. Chicago: Aldine.

Drori, I., Honig, B., \& Wright, M. (2009). Transnational entrepreneurship. An emergent field of study. Entrepreneurship Theory and Practice, 33(5), 1001-1022.

Dutia, S. G. (2011). Diaspora networks. A new impetus to drive entrepreneurship. Innovations, 7, Winter 2012, 65-72.

Frignal, E. (2007). Outsourced call centers and English in the Philippines. Word Englishes, 26(3), 331-345.

Geddes, A. (2001). Immigration and European integration: towards fortress Europe? Refugee Survey Quarterly, 20(1), 229-229

Ghaziani, A. \& Ventresca, M. J. (2005). Keywords and cultural change: Frame analysis of business model public talk 1975 - 2000. Sociological Forum, 20(4), 523-559.

Gillespie, K., Riddle L., Sayre, E. \& Sturges, D. (1999). Diaspora interest in homeland investment. Journal of International Business Studies, 30(3), 623-634.

Harima, A. (2014). Network dynamics of descending diaspora entrepreneurship: Multiple case studies with Japanese entrepreneurs in emerging economies. Journal of Entrepreneurship, Management and Innovation, 10(4), 65-92.

Hoang, H., \& Antocic, B. (2003). Network-based research in entrepreneurship: A critical review. Journal of Business Venturing, 18(2), 165-187.

Hornung, E. (2014). Immigration and the diffusion of technology: The Huguenot diaspora in Prussia. The American Economic Review, 104(1), 84-122.

International Organization for Migration (2014). Health in the Post2015 Development Agenda. The Importance of Migrants' Health for Sustainable and Equitable Development. Retrieved from https://www. 
iom.int/files/live/sites/iom/files/What-We-Do/docs/Health-in-the-Post2015-Development-Agenda.pdf (Accessed on 30th of March, 2015)

Kapur, D. (2001). Diasporas and technology transfer. Journal of Human Development, 2(2), 265-286.

Kloosterman, R., van der Leun, J., \& Rath, J. (1999). Mixed embeddedness: (In) formal economic activities and immigrant business in the Netherlands. International Journal of Urban and Regional Research, 23(2), 253-267.

Kuznetsov, Y. (2006). Diaspora networks and the international migration of skills: How countries can draw on their talent abroad. Washington DC: World Bank Publications (WBI Development Studies).

Levitt, P. (2001). Transnational migration: Taking stock and future directions. Global Networks, 1(3), 195-216.

Lindgardt, Z., Reeves, M., Stalk, G., \& Deimler, M. S. (2009). Business model Innovation. When the Game Gets Through, Change the Game. The Boston Consulting Group. Retrieved from http://www.bcg.com.br/documents/ file36456.pdf (Accessed on 11th of March, 2015).

Lodigiani, E. (2009). Diaspora externalities and technology diffusion. Economie internationale, 115(3), 43-64.

Magretta, J. (2002). Why business models matter. Harvard Business Review, $80(5), 86-92$.

Meyer, J.-B., \& Wattiaux, J.-P. (2006). Diaspora knowledge networks: Vanishing doubts and increasing evidence. International Journal on Multicultural Societies, 8(1), 4-24.

Morris, M., Schindehutte, M., \& Allen, J. (2005). The entrepreneur's business model: Toward a unified perspective. Journal of Business Research, 58(6), 726-735.

Nielsen, T. M. \& Riddle, L. (2009). Investing in peace: The motivational dynamics of Diaspora investment in post-conflict economies. The Journal of Business Ethics, 89(4), 435-448.

OECD (2013). International Migration Outlook 2013. OECD Publishing. Retrieved from http://dx.doi.org/10.1787/migr_outlook-2013-en (Accessed on 31st of October, 2014)

Osterwalder, A., \& Pigneur, Y. (2010). Business model generation: John Wiley \& Sons, Hoboken NJ.

Pavie, X., Hsu, E., Rödle, H. J. T., \& Tapia, R. O. (2013). How to define and analyze business model innovation in Service. Research Center, ESSEC Working Paper 1323. Retrieved from https://hal.inria.fr/file/index/ docid/921420/filename/WP1323.pdf (Accessed on 1st of June, 2015).

Rauch, J. E., \& Trindade, V. (2002). Ethnic Chinese networks in international trade. Review of Economics and Statistics, 84(1), 116-130.

Ray, S., \& Cardozo, R. (1996). Sensitivity and creativity in entrepreneurial opportunity recognition: A framework for empirical investigation. The Sixth Global Entrepreneurship Research Conference at Imperial College London. 
Riddle, L. (2008). Diaspora: Exploring their development potential. ESR Review, 10(2), 28-36.

Safran, W. (1991). Diasporas in modern societies: Myths of homeland and return. A Journal of Transnational Studies, 1(1), 83-99.

Saxenian, A. (2005). From brain drain to brain circulation: Transnational communities and regional upgrading in India and China. Studies in Comparative International Development, 40(2), 33-61.

Shane, S. (2000). Prior knowledge and the discovery of entrepreneurial opportunities. Organization Science, 11(4), 448-469.

Tedlock, B. (1991). From participant observation to the observation of participation: The emergence of narrative ethnography. Journal of Anthropological Research, 47(1), 69-94.

The Department of Tourism in Philippines (2003). Visitor arrivals to the Philippines by country of residence January-December 2003, Retrieved from http://www.wowphilippines.com.ph/ (Accessed on 10th of March, 2015)

The Department of Tourism in Philippines (2013). Visitor arrivals to the Philippines by country of residence January-December 2013, Retrieved from http://www.wowphilippines.com.ph/, (Accessed on 10th of March, 2015)

Tölölyan, K. (1996). Rethinking diaspora(s): Stateless power in the transnational moment. A Journal of Transnational Studies, 5(1), 36-36.

Tung, R. L. (2008). Brain circulation, diaspora, and international competitiveness. European Management Journal, 26(5), 298-304.

Vemuri, S. (2014). Formation of Diaspora Entrepreneurs. ZenTra Working Papers in Transnational Studies 41/2014 (November 2014). Retrieved from http://papers.ssrn.com/sol3/papers.cfm?abstract_id=2519432 (Accessed on 10th of March, 2015)

Vemuri, S. (2015). Tracing the history of Diaspora business. Paper presented at the 1st Global meeting of The Diaspora \& Business Project, Mansfield College, Oxford, July 15-16, 2015

Wahlbeck, Ö. (2004). Turkish immigrant entrepreneurs in Finland: Local embeddedness and transnational ties. Transnational Spaces: Disciplinary Perspectives. Willy Brandt Conference Proceeding. Edited by Maja Povrzanovic Frykman'. Retrieved from http://ir.nmu.org.ua/bitstream/ handle/123456789/123290/cf519b6ed5914d52a1b3ec489ed283c2. pdf?sequence=1\#page=102. (Accessed on 18th of June, 2015)

Worldbank. (2014). Migration and Remittances: Recent Developments and Out-look. Special Topic: Forced Migration. Migration and Development Brief, 23: 1-2. Retrieved from http://siteresources. worldbank.org/INTPROSPECTS/Resources/3349341288990760745/ MigrationandDevelopmentBrief23.pdf (Accessed on 19th of February, 2015) 
Zabin, C., \& Hughes, S. (1995). Economic integration and labor flows: stage migration in farm labor markets in Mexico and the United States. International Migration Review, 29(2), 398-422.

Zott, C., Amit, R., \& Massa, L. (2011). The Business Model: Recent Developments and Future Research. Journal of Management, 37(4), 1019-1042.

\begin{abstract}
Abstrakt (in Polish)
Praca ta bada sposoby jakimi członkowie diaspory osiqgaja innowacyjne modele biznesu, korzystajac ze swoich unikalnych zasobów. Hipotezq niniejszej pracy jest to, że specyficzne środowisko i unikalne zasoby firm diaspory z powodu różnych źródet informacji i doświadczeń, a także wielu sieci powiqzań, przyczyniajq się w charakterystyczny sposób do tworzenia innowacyjnego modelu biznesowego. Badamy rynek szkół języka angielskiego na Filipinach, ustanowiony przez diaspory Wschodniej Azji, które wprowadzajq innowacyjny model biznesowy do tradycyjnych szkół języka angielskiego. Dwa studia przypadków zostały przeprowadzone w szkołach japońskiej diaspory. Ich działalność jest analizowana za pomoca szablonu modelu biznesowego (Osterwalder \& Pigneur, 2010), następnie porównana z konwencjonalnym modelem biznesowym. Empiryczne przypadki pokazujq, że firmy diaspory wykorzystujq wiedzę o kraju ojczystym oraz uwarunkowania kraju zamieszkania, a także swoje liczne koneksje w różnych miejscach i układach, w celu identyfikacji unikalne możliwości dziatania, co prowadzi do powstania innowacyjnego modelu biznesowego.
\end{abstract}

Słowa kluczowe: szablon modelu biznesowego, diaspora Wschodniej Azji, transnarodowa przedsiębiorczość, rozpoznawanie możliwości biznesowych, mieszane zakorzenienie.

\title{
Biographical note
}

Aki Harima is a research assistant and a PhD candidate at the Chair of Small Businesses \& Entrepreneurship (LEMEX) at the University of Bremen, Germany. She acquired her MSc in Management at the University of Mannheim (Germany) and BSc in Business Administration at the University of Kobe (Japan). She investigates entrepreneurial activities of diasporans from developed countries in developing and emerging countries from various perspectives such as individual intercultural competencies, networks, strategic management and innovation.

Sivaram Vemuri is currently an Associate Professor of Economics, Waterfront Darwin Business School, Faculty of Law, Education, Business and Arts, Charles Darwin University, Darwin, NT 0909, Australia, and the Director of Administration, Finance and Personnel, Inter-disciplinary.net, Oxford. 


\title{
Enabling Business Model Change: Evidence from High-Technology Firms
}

\author{
Christiana Müller', Stefan Vorbach ${ }^{2}$
}

\begin{abstract}
Companies today face volatile environments, short product life cycles, and changing customer requirements, which is especially the case in high-technology fields. In such environments, concentrating only on technological and product innovations is not sufficient to gain competitive advantages. Instead, companies need innovative business models in order to stand out from their competitors. To successfully change business models, companies require appropriate competencies. Thus, the objective of this research is to identify how companies can prepare their business model(s) to counteract environmental changes flexibly. With the aid of the chosen exploratory, qualitative research design, we investigate companies operating in hightechnology branches. In total, 20 companies participated in our study. The interviews were conducted with CEOs, vice-presidents, product managers or other managers responsible for business model developments. The research revealed that companies can prepare the business model and its elements ex ante through developing capabilities in order to raise the flexibility of the business model. These capabilities have to be developed with regard to several internal and external issues driving these changes.
\end{abstract}

Keywords: business model, business model innovation, capabilities for change, flexibility, high-technology.

\section{INTRODUCTION}

Companies operate in an environment determined by a fast pace, volatility and uncertainty. To survive, they increasingly have to find new ways to gain a competitive advantage. A study by The Economist Intelligence Unit (2005) revealed that $55 \%$ of the CEOs interviewed find new business models to be a greater source of innovation than new products or services. The reason for the rising interest in new business models was explained through increasing choices of products and services on the market and the lack of differentiation between

1 Christiana Müller, Dr., Graz University of Technology, Institute of General Management and Organization, , Kopernikusgasse 24 IV, 8010 Graz, Austria, tel. +43 316873 7502, e-mail: christiana.mueller@tugraz.at.

2 Stefan Vorbach, Prof. Dr., Graz University of Technology, Institute of General Management and Organization, Kopernikusgasse 24 IV, 8010 Graz, Austria, +43 316873 7500, e-mail: stefan.vorbach@tugraz.at. 
them. Moreover, business models change due to commercialization of new technologies (Chesbrough and Rosenbloom, 2002, p. 532), open innovation activities within the company or cooperative partnerships with research institution, suppliers and so on ( Schuh, Friedli and Kurr, 2005, p. 9; Chesbrough, 2006, p. 10). Thus, the development of a new business model is regarded as an essential key to foster firm performance (Zott, Amit and Massa, 2011, p. 1031) and to differentiate from competitors (Styles and Goddard, 2004, p. 65).

High-technology companies operating in sectors like the electronic or pharmaceutical industry do their business in a rapidly changing environment that is shaped by uncertainty in the market and technology, high risks and intensive competition (Evans, 1991, p. 69; Brad, 2007, p. 18). These high-technology companies, characterized for example by a high level of innovativeness, intensive research and development (R\&D) expenditure, highly skilled employees, participation in cooperative networks and a fast pace in terms of obsolescence of products and technologies (ZakrzewskaBielawska, 2010, p. 94), are more often confronted with radical change. Therefore, flexibility is required in order to redefine strategies continuously and find new ways of gaining a competitive advantage (Evans, 1991, p. 69). Flexibility is also required for the business model (BM). It is, hence, not surprising that a study by KPMG International $(2006$, p. 4) postulates the need to develop a flexible and profitable business model by reviewing it on a regular basis, developing a unique value proposition, and working together with partners to pursue new opportunities or strengthen the company's position in the value chain. Moreover, Schuh et al. $(2005$, p. 9) demand an intelligent business model having the capability of being as flexible as needed.

In literature, discussions about the definition of flexibility show a broad variety: Flexibility is described as capacity to adapt (Golden and Powell, 2000, p. 376) and the ability to change oneself in order to remain viable (Krijnen, 1979 , p. 64). From a systems perspective, flexibility can be explained as capability to adaption/change (De Toni and Tonchia, 2005, p. 526) or as the property of a system that can be easily changed (Ferguson, Siddiqi, Lewis and de Weck, 2007, p. 3). Halecker and Hartmann (2013, p. 3) argued that a systemic view is also applicable for business models because they are complex and due to the fact that they are models of a company, they can be seen as open and social systems. Furthermore, a BM can be explained in the form of elements and the relationship between these elements (e.g. Osterwalder and Pigneur, 2010), which is also a characteristic of systems. Thus, the understanding of flexibility from a systems perspective can be transferred in order to explain the flexibility of business models.

Research on BM flexibility is very sparse. Mason and Mouzas (2012, p. 1361) describe the flexibility in business models through adaptability 
in network architecture, market integration, coordination, and business relationships in order to gain better business performance. Taking the airline industry as an example, Nair, Palacios and Tafur $(2011$, p. 3) explain that a flexibility and adaptability layer inherent in the BM can be used for constantly "analyzing, benchmarking, acquiring and strengthening" of necessary competencies for maintaining business performance. These scholars especially highlight the importance of developing and maintaining core competencies (e.g. brand maintenance, product diversification or incremental innovation) to provide flexibility in the BM. Literature on business models (containing several research studies) reflects on capabilities necessary for changing the BM. Factors driving and inhibiting BM changes need specific capabilities in order to enable the change. Driving factors are, for example, rapidly changing customer requirements, the development of customers to co-creators or the deconstruction of the value chain into smaller segments (Schuh et al., 2005, p. 9; Romero and Molina, 2009, p. 403; Capgemini Consulting, 2010, p. 12). In contrast, inhibiting factors are inertia regarding existing competencies or technologies, just to name a few (Chesbrough, 2010, p. 358). As descriptions on capabilities are quite general, Schneider and Spieth (2013, p. 21) emphasized that more in-depth research is required in defining capabilities to innovate the BM, depending on the particular element and type of business model innovation, and the need to develop these capabilities ex ante. Due to the existence of solely general descriptions of capabilities, such a holistic description is still missing. Referring to Schneider and Spieth (2013, p. 21), they further explain the need for an ex ante development of capabilities for single elements, as well as for the overall BM. Using this approach, we see flexibility as the ability of the BM and its single elements to adapt to changes and exploit opportunities in the future. This postulates the need to develop capabilities and properties enabling flexibility in the BM and its single elements, as also explained in the literature on flexibility in systems (e.g. Brehm, 2003, p. 45). Consequently, the focus and goal of our paper is to provide an integrated view about properties and capabilities necessary, in single $\mathrm{BM}$ elements and the overall $\mathrm{BM}$, to provide the flexibility required to adapt to changing needs.

The remainder of this paper is organized as follows: The next section provides the related theoretical background on business models, BM change and capabilities necessary to change the BM. After the description of the research design, the empirical findings on identified capabilities and properties enabling BM change are explained. Next, the empirical findings are discussed and implications are given for practitioners and research. The paper ends with a summary of the findings and limitations. 


\section{Business model and necessary capabilities to change the BM}

In general, "a business model describes the rationale of how an organization creates, delivers, and captures value" (Osterwalder and Pigneur, 2010, p. 14). The emergence of the BM concept is mainly perceived with the appearance of the new economy and e-commerce between 1998 and 2002. Afterwards, the concept was also increasingly adopted in the "old economy" and evolved to become a strategic component. (Wirtz, 2011, p. 14) The development of the BM concept in different scientific disciplines led to various definitions, but a general understanding does not exist so far. This is also true for concepts describing business model innovation.

Business model definitions appear in different forms and degrees of abstraction, like in a narrative description (e.g. Magretta, 2002, p. 87), in form of graphical frameworks (e.g. Osterwalder and Pigneur, 2010, p. 18 ) or described as activity system (e.g. Zott and Amit, 2010, p. 217). The majority of definitions consider the BM as an abstract view on the company, with the focus on describing different dimensions or elements that fit together and shape the BM. These descriptions correspond with specified graphical frameworks, but also differ in the number of elements defined and their detailed description and complexity. Also our interview partners had differing granularity when describing their BM. A broad and common understanding existed about the necessity to know who the customers are and what value in terms of products and services are delivered to them. In turn, other practitioners explained the value creation and value capture as elementary elements. Summing up, we experienced in our interviews that companies deem four elements relevant (see figure 1): The customer element representing the target group of the company's offerings and channels to reach them; the value proposition explaining what is delivered to the customer in order to fulfill the needs of the target group; the value creation describing how the value is generated; and the value capture determining the added value in form of revenues generated from the value proposition as well as the costs incurred as a result of value creation. This explanation of a BM is not completely new, but represents the perception of a BM from the perspective of our interviewed practitioners.

Besides the definition of specific BM elements, their interrelation and alignment is also important. This becomes more transparent through cause and effect relationships (Hedman and Kalling, 2003, p. 53). Thus, the BM elements identified should not be treated as stand-alone elements; rather they are connected and influence each other. For example, when our interview partners reported about the customer focus, the alignment of the entire $\mathrm{BM}$ according to this focus is emphasized, describing implicitly the alignment of all BM elements towards customer needs and, therefore, the 
customer element. Hence, the BM in figure 1 represents the interrelationship between the BM elements as well.

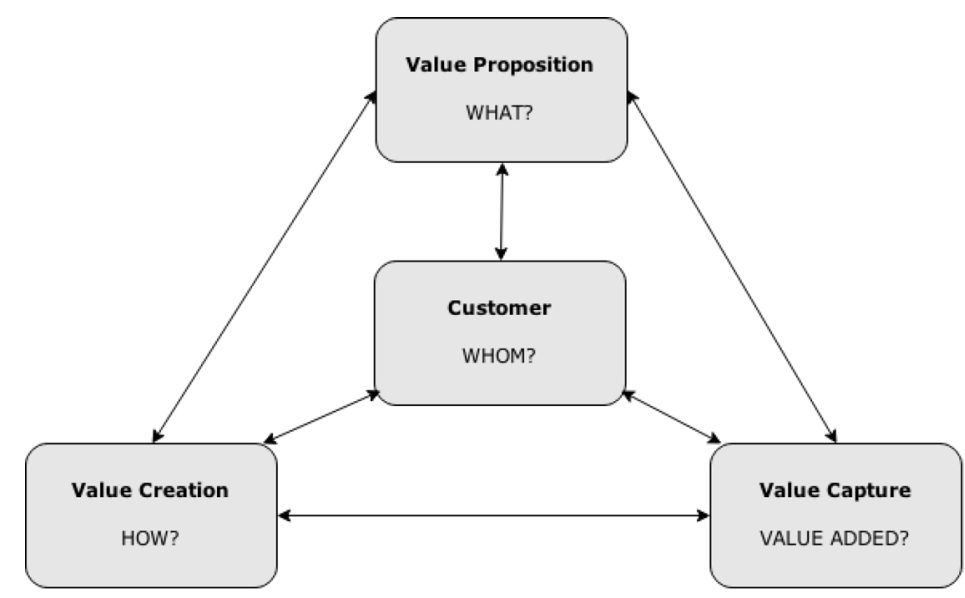

Figure 1. Business model elements

Source: Müller (2014).

Once the BM concept established in the new economy, companies in the "old economy" started to rethink their existing BM. With these changes in established business models, terms like business model change or business model innovation emerged. This new scientific discussion has become increasingly important in the past few years. (Zollenkop, 2006, p.31)

In order to recognize the need for BM changes and turn the BM change into success, companies need to develop specific capabilities. Within BM innovation literature the identification of capabilities and basic conditions (e.g. organizational culture) gained more importance in recent years. One particular concept discussed in that context is the dynamic capabilities concept. Dynamic capabilities are a prerequisite for changing a company's way of doing business in order to survive and prosper under constantly changing conditions (Helfat et al., 2007, p. 1). These are an advancement of the resource-based view because this theoretical explanation is criticized as being too static. Teece, Pisano and Shuen (1997, p. 516) mainly contributed to this concept's development by providing one of the first definitions: Dynamic capabilities are "the firm's ability to integrate, build and reconfigure internal and external competences to address rapidly changing environments". In their view, the dynamism is determined by the capacity of the organization to renew its competencies according to the changing business environment. In 
a BM, resources and competencies are an integral part of the value creation element. Thus, dynamic capabilities are seen as relevant for the BM change. Several scholars built on the research stream originated by Teece et al. (1997) and mentioned sensing, seizing and reconfiguration as important capabilities when it comes to changes in the BM. In concrete, these dynamic capabilities are manifested in sensing market or technological opportunities, exploiting these opportunities by changing the $\mathrm{BM}$ and preparing the organization according to the new direction. (Dottore, 2009, p. 491; Mezger, 2013, p. 6) Further, the establishment of learning processes plays an important role. Learning processes should support companies to handle problems and challenges in the industry and to re-combine existing knowledge (Najmaei, 2011, p. 167).

Changing the BM is a managerial task. Mitchell and Coles (2003, p. 20) brought into discussion that the CEO has to be aware of the importance of changing the BM in order to better serve customers and other stakeholders. Management tasks span the sensing and seizing of both opportunities and threats and preparing the organization for that. The development of dynamic capabilities for changing the BM, as previously explained, is thus helpful. Furthermore, managers are also essential for eliminating barriers to change and enhancing the opportunity to implement the new BM successfully. However, managers themselves can be a barrier to change if they are not skilled and willing to change the existing BM (Massa and Tucci, 2013, p. 13; Gassmann, Frankenberger and Csik, 2014, p. 341). The significance of a strong leadership when changing the BM was also revealed in the study by KPMG International (2006, p. 59). Deschamps $(2005$, p. 35) explained that the implementation of a new BM requires a "pragmatic architect" who is able to define the operating system in detail and possesses project management skills. At the same time, the importance of establishing a culture that appreciates change is highlighted by several scholars. According to Gassmann et al. (2014, p. 342), corporate culture is an important success factor in change activities.

As shown in this section, dynamic capabilities, management and leadership, as well as a corporate culture appreciating change are important factors when shifting the BM. Our study takes these findings into consideration.

\section{RESEARCH METHODS}

For this research, an exploratory, qualitative research design in the field of high-technology industries was chosen. The qualitative research design is appropriate when questions are formulated as explorative what-questions (Yin, 2009, p. 28) but also when the goal is to understand meanings or events and actions in a specific context (Maxwell, 2005, p. 22). The high-technology 
industry seems to be an appropriate context for this research because high-technology companies face a high speed of change and volatility and technological changes are very often accompanied by BM changes (Chesbrough and Rosenbloom, 2002, p. 532).

As a basis for our research process, the approaches proposed by Eisenhardt (1989) and Gioia, Corley and Hamilton (2012) were used. The procedure described by Eisenhardt $(1989$, p. 532$)$ is a combination of the case study method and the grounded theory approach. The method explained by Gioia et al. (2012, p. 1) relies entirely on grounded theory, but aims to apply more rigor in this inductive approach. Additional reasons for choosing a combination of these two processes are that both research procedures are especially advantageous in new research topics. Both consider the existing literature prior to the study and both are established research procedures in their fields.

\section{Case selection and data gathering}

In our study, the procedures of theoretical and purposive sampling were used to choose the company cases. Theoretical sampling is an iterative process in which data gathering and data analysis alternate (Birks and Mills, 2010, p. 69) and the sample is not determined in advance. Alternate data gathering and analysis continues until theoretical saturation is reached and adding more material does not result in additional insights. With purposive sampling, the cases are chosen purposefully for the study (e.g. only extreme cases, typical cases, access to interview partners) (Flick, 2014, p. 109). For our research, a mixture of theoretical and purposive sampling was chosen because some criteria for selecting the cases were determined in advance. This complies with purposive sampling as these criteria help to identify cases that are best suited to examine the phenomenon. Pragmatic reasons like the accessibility of interview partners were also taken into consideration. In line with theoretical sampling, the cases actually investigated were chosen in an iterative process of data gathering and analysis. The following criteria were defined for this purpose:

- Companies are classified as high-technology and medium-high technology according to NACE Rev2. According to this classification, companies established in group 21 - manufacturing of basic pharmaceutical products and pharmaceutical preparations, group 26 - manufacturing of computer, electronic and optical products, as well as group 30.3 - manufacturing of aircraft, spacecraft and related machinery are designated as high-technology. (EUROSTAT, 2014) In addition to companies which are defined by NACE Rev. 2 as purely high-technology, companies in the medium-high technology 
classification were also included in the sample. We did so because the boundaries between the classification of medium-high and high-technology are sometimes blurring and we assumed that these companies face the same challenges as purely high-technology companies. Thus, medium-high technology companies are considered if innovation is seen as an important issue in their business (e.g. obtained innovation award).

- Companies are independently managed (e.g. single organizations, independent divisions or business units).

- Companies are established and of medium or large size.

- Headquarters and/or single divisions or business units are located in Austria. This restriction has pragmatic reasons, such as access to interview partners and additional materials (e.g. annual reports).

Table 1 contains the list of companies in the sample. To guarantee anonymity, we labeled the companies alphabetically starting with A, like Company A. The table further presents the company's NACE classification as well as information about the number of employees in the corporate group and the business unit/subsidiary considered, the location of the headquarters (HQ) and the position of the interview partner in the company.

Table 1. List of high-technology companies included in the research

\begin{tabular}{|c|c|c|c|c|c|}
\hline Company & $\begin{array}{l}\text { Number } \\
\text { of em- } \\
\text { ployees }\end{array}$ & $\begin{array}{l}\text { NACE } \\
\text { classify- } \\
\text { cation }\end{array}$ & Detailed description & $\mathrm{HQ}$ & $\begin{array}{l}\text { Position interview } \\
\text { partner }\end{array}$ \\
\hline Company A & 1,394 & 26.110 & $\begin{array}{l}\text { Development and factory-made } \\
\text { micro-electronic components, } \\
\text { so called "Micro-Chips". }\end{array}$ & AUT & $\begin{array}{l}\text { Senior Vice } \\
\text { President \& } \\
\text { General Manager }\end{array}$ \\
\hline Company B & $\begin{array}{l}2,860 / \\
150\end{array}$ & 29.310 & $\begin{array}{l}\text { Development of electromagnets } \\
\text { as well as electromagnetic } \\
\text { brakes. }\end{array}$ & $\mathrm{NE}$ & $\begin{array}{l}\text { CEO of one } \\
\text { Business Unit }\end{array}$ \\
\hline Company C & 100 & 26.110 & $\begin{array}{l}\text { Microcontroller-based motor } \\
\text { controls and controls for } \\
\text { ergonomic solutions in the } \\
\text { furniture industry. }\end{array}$ & AUT & $\begin{array}{l}\text { Business Unit } \\
\text { Manager \& } \\
\text { Director Sales }\end{array}$ \\
\hline Company D & $\begin{array}{l}5,266 / \\
3,013\end{array}$ & 28.290 & $\begin{array}{l}\text { Production and sales of } \\
\text { public communication } \\
\text { systems for switching and } \\
\text { transition technology, private } \\
\text { communication systems and } \\
\text { traffic control technology. }\end{array}$ & AUT & $\begin{array}{l}\text { Chief Marketing } \\
\text { Officers for the } \\
\text { Corporate Group } \\
\text { \& Vice President } \\
\text { for Marketing \& } \\
\text { Communications } \\
\text { for a Business Unit }\end{array}$ \\
\hline Company E & $\begin{array}{l}8,284 / \\
1,787\end{array}$ & $\begin{array}{l}26.300 / \\
26.541\end{array}$ & $\begin{array}{l}\text { Research, development, } \\
\text { production and sales of } \\
\text { electronic and electronic } \\
\text { components of all kinds. }\end{array}$ & AUT & $\begin{array}{l}\text { Head of Business } \\
\text { Development }\end{array}$ \\
\hline Company F & $\begin{array}{l}>6,500 / \\
540\end{array}$ & 26.110 & $\begin{array}{l}\text { Development of equipment, } \\
\text { specific machines and } \\
\text { accessories for the } \\
\text { semiconductor industry. }\end{array}$ & USA & $\begin{array}{l}\text { COO \& Managing } \\
\text { Director } \\
\text { Operations Head }\end{array}$ \\
\hline
\end{tabular}




\begin{tabular}{|c|c|c|c|c|c|}
\hline Company G & $\begin{array}{l}1,500 / \\
390\end{array}$ & $\begin{array}{l}23.430 / \\
23.990\end{array}$ & $\begin{array}{l}\text { Manufacturing of electrical } \\
\text { insulating materials, technical } \\
\text { laminates and composites. }\end{array}$ & AUT & $\begin{array}{l}\text { Manager Business } \\
\text { Development }\end{array}$ \\
\hline Company $\mathrm{H}$ & $\begin{array}{l}38,000 / \\
320\end{array}$ & 21.200 & $\begin{array}{l}\text { Manufacturing of } \\
\text { pharmaceutical specialties } \\
\text { and additional pharmaceutical } \\
\text { products. }\end{array}$ & $\mathrm{DE}$ & $\begin{array}{l}\text { Head of Change \& } \\
\text { Innovation }\end{array}$ \\
\hline Company I & 297 & 26.700 & $\begin{array}{l}\text { Manufacturing of fine- } \\
\text { mechanical and optical } \\
\text { instruments and machines. }\end{array}$ & AUT & $\begin{array}{l}\text { Marketing \& } \\
\text { Global Product } \\
\text { Manager }\end{array}$ \\
\hline Company J & $\begin{array}{l}>1,600 / \\
>920\end{array}$ & 26.510 & $\begin{array}{l}\text { Development, manufacturing } \\
\text { and distribution of high- } \\
\text { precision } \\
\text { PC-based measurement } \\
\text { systems. }\end{array}$ & AUT & $\begin{array}{l}\text { Development } \\
\text { Corporate Plant }\end{array}$ \\
\hline Company K & 300 & 28.290 & $\begin{array}{l}\text { Manufacturing of individual } \\
\text { production systems and } \\
\text { automation-solutions. }\end{array}$ & AUT & $\begin{array}{l}\text { Head of Business } \\
\text { Development }\end{array}$ \\
\hline Company L & $640 / 71$ & 26.510 & $\begin{array}{l}\text { Development, manufacturing } \\
\text { and distribution of high- } \\
\text { precision PC based } \\
\text { measurement systems. }\end{array}$ & $\mathrm{DE}$ & CEO \\
\hline Company $\mathrm{M}$ & 980 & $\begin{array}{l}26.300 / \\
26.510\end{array}$ & $\begin{array}{l}\text { International provider of } \\
\text { communication and information } \\
\text { solutions for safety-critical } \\
\text { fields. }\end{array}$ & AUT & $\begin{array}{l}\text { Product Manager } \\
\text { \& Business } \\
\text { Development }\end{array}$ \\
\hline Company $\mathrm{N}$ & n.a./90 & 20.140 & $\begin{array}{l}\text { Manufacturing of silage } \\
\text { additives and probiotics. }\end{array}$ & AUT & CEO \\
\hline Company 0 & $\begin{array}{l}31,961 / \\
1,000\end{array}$ & $\begin{array}{l}21.200 / \\
20.200\end{array}$ & $\begin{array}{l}\text { Development, production and } \\
\text { sales of special pharmaceutical } \\
\text { products and active agents. }\end{array}$ & $\mathrm{DE}$ & $\begin{array}{l}\text { Executive Vice } \\
\text { President \& } \\
\text { General Manager }\end{array}$ \\
\hline Company $\mathrm{P}$ & 2,450 & 26.510 & $\begin{array}{l}\text { All-in-one solution provider of } \\
\text { intra-logistic complete solutions } \\
\text { and automated warehouse } \\
\text { systems. }\end{array}$ & AUT & CEO \\
\hline Company Q & 7,321 & 26.110 & $\begin{array}{l}\text { Manufacturer of high-end } \\
\text { printed circuit boards. }\end{array}$ & AUT & $\begin{array}{l}\text { Business } \\
\text { Development } \\
\text { Corporate Group } \\
\text { \& CFO Business } \\
\text { Unit }\end{array}$ \\
\hline Company R & 730 & $\begin{array}{l}28.120 / \\
26.110\end{array}$ & $\begin{array}{l}\text { Planning, manufacturing and } \\
\text { distribution of hydraulics, } \\
\text { electronics, sensoric, electrical } \\
\text { engineering and electrical } \\
\text { installations. }\end{array}$ & AUT & $\begin{array}{l}\text { Head Business } \\
\text { Development }\end{array}$ \\
\hline Company S & $\begin{array}{l}>450 / \\
57\end{array}$ & 28.290 & $\begin{array}{l}\text { Planning and developing of } \\
\text { special machine projects. }\end{array}$ & $\mathrm{DE}$ & CEO \\
\hline Company $\mathrm{T}$ & 113 & 28.999 & $\begin{array}{l}\text { Development of technologies } \\
\text { for energy generation; } \\
\text { leading specialist in plant } \\
\text { manufacturing, providing of } \\
\text { customized turnkey solutions. }\end{array}$ & AUT & $\begin{array}{l}\text { Member Executive } \\
\text { Board \& CSO }\end{array}$ \\
\hline
\end{tabular}

Source: Müller (2014). 
Data was gathered by means of semi-structured expert interviews with representatives from the top management team (e.g. CEO, executive vice president). Semi-structured interviews are a common method of data gathering in qualitative research and are used when the interview partner occupies complex knowledge on a specific topic (Gioia et al., 2012, p. 5). Expert interviews are a special form of semi-structured interviews, where the interview is conducted with experts (Flick, 2014, p. 227). Experts are people who command specific knowledge, information and competencies in their field, are responsible for the design, implementation and controlling of a solution or have privileged access to information (e.g. decision processes) (Bogner, Littig and Menz, 2009, p. 7). We decided to interview one person at each company due to the difficulty of obtaining an appointment with appropriate interview partners. The interviews were conducted face-to-face at the company site between July 2013 and May 2014. The length of the interviews ranged from 0.5 hour up to 1.5 hours.

In qualitative studies, especially the grounded theory, researchers are skeptical towards considering theoretical knowledge prior conducting the study. However, both Eisenhardt (1989, p. 536) and Gioia et al. (2012, p. 12) recommend to consider the existing literature and develop theoretical constructs at the beginning. Nevertheless, they advise to treat these theoretical constructs as temporary available that can be rejected or changed during the process. We structured our interview guideline to start with discussions about the existing BM of the company, threats and opportunities that might lead to BM changes, capabilities necessary to change the BM and how companies prepare their BM in order to change it according to emerging opportunities and threats. To provide the basis for an open dialogue, our questions were worded in a very open manner and we had the opportunity to probe and discuss certain aspects in detail. Prior to the interview, the interviewees received only the rough topics of the interview. This should prevent from preparing the exact answers to all questions in advance. Besides the primary data gathered in the interviews, secondary data in the form of information on web sites, press releases or documents and reports available from the company were considered. These secondary data were used to gain additional insights into the companies.

\section{DATA ANALYSIS}

All 20 interviews were analyzed by using the MAXQDA 11 software tool. For the data analysis procedure, we chose a combination of the structuring qualitative content analysis described by Mayring (2010, p. 67) as well as the analysis explained by Gioia et al. (2012, p. 6) which is based on grounded 
theory. We developed a provisional coding scheme that was used for structuring the data gathered. This coding scheme was grounded on the topics of our semi-structured interview guideline. Afterwards, the structured text was coded in order to develop 2nd order themes as described by Gioia et al. $(2012$, p. 6). A system of categories was established by aggregating these 2nd order themes. The analysis was conducted first of all for each individual company, followed by a cross-case analysis where the results of individual cases were compared and critical categories generated. Table 2 provides a snapshot of the coding scheme and category development. The previously considered theory increased theoretical sensitivity and was supportive in category generation. These steps were conducted in an iterative process until theoretical saturation was reached. In our research, theoretical saturation was achieved when no new categories emerged even if adding new empirical material. To refine categories and develop causal relationships between them, the original data were screened again with the system of categories emerging. This follows the idea of deductive and more confirmatory content analysis, as explained in the structuring content analysis by Mayring (2010, p. 67).

Table 2. Snapshot of coding scheme

\begin{tabular}{|c|c|c|}
\hline Paraphrase & $2^{\text {nd }}$ order theme & Category \\
\hline $\begin{array}{l}\text { Accepting change as something normal and understanding why } \\
\text { the change has happened. There must be a strong appreciation } \\
\text { of dealing with something new and a basic readiness to make } \\
\text { changes. }\end{array}$ & \multirow[t]{2}{*}{$\begin{array}{l}\text { Willingness to } \\
\text { change }\end{array}$} & \multirow[t]{4}{*}{$\begin{array}{l}\text { Change } \\
\text { readiness }\end{array}$} \\
\hline $\begin{array}{l}\text { Have no taboos and be open for every topic. It is important } \\
\text { to realize that every business model has an expiry date; the } \\
\text { openness to say that the company or the business model is } \\
\text { replaceable must be realized. }\end{array}$ & & \\
\hline $\begin{array}{l}\text { Flexible communication is important to mediate between } \\
\text { customer needs and requirements and what the company is } \\
\text { able to provide. }\end{array}$ & \multirow[t]{2}{*}{ Communication } & \\
\hline $\begin{array}{l}\text { The person responsible for the change needs to communicate } \\
\text { it. Commitment can only be generated through communication }\end{array}$ & & \\
\hline
\end{tabular}

\section{FINDINGS}

As basis for identifying enablers in terms of properties and capabilities providing flexibility, our BM consisting of four elements - value proposition, value creation, value capture and the customer element (Müller, 2014, p. 156) - was used. These properties and capabilities were identified with respect to internal and external factors driving changes in the BM, and are necessary for covering these driving factors. More precisely, properties and capabilities 
were identified in three BM elements: Value proposition, value creation and the customer element. In addition, companies reported about capabilities necessary to prepare the overall BM for a change. Table 2 summarizes the properties and capabilities identified.

Table 3. Empirical findings on capabilities and properties enabling BM change

\begin{tabular}{ll}
\hline & Capabilities/Properties for BM change \\
\hline Value Proposition & Product modularity \\
Value Creation & Establishment of external partnerships \\
& Competence robustness \\
Customer & Task and process versatility \\
& Sense and accumulate information on customer needs \\
& Market sensitivity \\
Entire Business Model & Change readiness - openness and willingness to change, open \\
& communication, having the right people \\
& Management of risks and learning \\
& Leadership and commitment \\
& Organizational preparation \\
\hline
\end{tabular}

Source: Müller (2014, p. 182).

The following detailed descriptions are reinforced by providing one to two explanatory examples from the empirical data gathered.

\section{Capabilities and properties identified in specific BM elements}

Product modularity was identified as driving the flexibility potential at the value proposition. Customers require tailor-made solutions that suit to their needs perfectly. Thus, companies need to find a way to develop and provide products and services according to these needs and have to develop the value proposition accordingly. Company $\mathrm{M}$ explains the requirements for modular products as follows (oral information, 21 April 2014):

"[...] our customers require tailor-made solutions. It is extremely costly to provide customized solutions every time. Thus, 10 years ago we started to manufacture products providing flexible, tailor-made solutions. [...]"

Thus, the companies interviewed highlighted the importance of modular product architecture in order to reduce the product's complexity and adapt to market trends and customer requirements or pursue growth activities within the company.

In the value creation, three flexibility potentials were identified: Establishing external partnerships, competence robustness as well as task and process versatility. The establishment of external partnerships is helpful 
because network partners provide flexibility in many ways. Partners can be seen as a resource possibly offering external competencies; or they provide capacities (e.g. in manufacturing) if internal capacities are fully utilized. For example, company $\mathrm{P}$ uses network partners to source capacities in terms of manufacturing or development. They treat the external environment as a slack resource that provides flexibility. Moreover, partners provide new and interesting topics (e.g. market trends, technological developments) that are important to seize future BM opportunities or prepare for future restrictions and regulations, which is especially important in the pharmaceutical industry.

Competence robustness was also emphasized by the companies interviewed. They describe competence robustness by aligning the BM on core competencies that can be extended through innovation if opportunities for new ventures emerge. This goes along with the establishment of external partnerships because non-core competencies and resources are sourced externally. These robust core competencies act as a "tower of strength" in an area of uncertain and unforeseeable developments. Moreover, they provide the basis for the development of a company's value proposition and also stability in uncertain and volatile environments. Enhancing these core competencies can create additional opportunities (e.g. new value proposition) to perceive further growth potentials and outstanding results. Company A possesses the core competency of developing microchips on which the BM is based on. In order to serve customers in a better way, their core was extended by adding additional distribution channels.

Companies further reported on the importance of task and process versatility for handling change requirements. A certain degree of versatility is needed, mainly in perception of specific customer or reorganization requirements due to growth activities or cost pressure. In the BM of company $\mathrm{C}$, processes are clearly defined to ensure the quality of products. Nevertheless, the company attempts to adjust fitting to customer needs (e.g. receive value proposition faster).

In the customer element, the capability to sense and accumulate information on customer needs was reported to be important. The interviewed companies consider the customer as the core of their BM. Growth activities pursued by the company and the demand to fulfill customer needs require proximity to the customer in order to anticipate and integrate needs into the $\mathrm{BM}$ at an early stage. This requires sensing of customer requirements, but also accumulating and processing them throughout the company. Company $G$ reported that information about customer needs has to be available for everyone in the company. For this purpose, they implemented a CRM tool that supports them in providing the customer information. 


\section{Capabilities and properties identified in the overall BM}

Several capabilities were reported that ensure the changeability of the overall BM. Thus, they are not assigned to a specific BM element. These capabilities are seen as meta-capabilities because they are considered as a general precondition enabling change.

Sensitivity towards changes and developments in the market is imperative for sensing and seizing market trends. It helps to identify and fulfill customer requirements and to prepare in advance for handling legal restrictions and regulations as well as situations of crisis. Companies take several actions in this respect, such as constant market research and analysis, discussions with branch experts or simulation of developments in the market. To increase sensitivity towards market developments in the pharmaceutical industry, company $\mathrm{O}$ works closely together with public authorities and customers. In doing so, company $\mathrm{O}$ participates in committees to obtain information and discuss about future reforms and regulations early on. Furthermore, company $\mathrm{O}$ organizes special events with customers to debate on current and future issues in pain therapy in order to develop corresponding solutions.

Change readiness expresses the general ability of a company to handle situations of change. It is mainly shaped by the corporate culture, describing conventions on how to handle activities of change within the organization. Thus, it is defined as how changes are communicated within the organization as well as how employees experience and deal with unfamiliar situations. Factors such as openness towards and willingness to change, open communication and appropriate people to make the new direction possible are required. Especially changes in the BM very often lead to changes in the way how the company operates. This often goes in line with skepticism and fears of employees. Company R, therefore, emphasizes to have no taboos and be open for every topic. They draw the attention to the fact that every BM has an expiry date and business models are replaceable.

Both, risks and learning need specific management processes, institutionalized within the company. Companies need to be aware in advance of the risks involved in the actions taken, but they also need to take appropriate risks in order to learn and improve. Therefore, an active management of risks and learning is advisable. Risks taken in new opportunities may provide additional revenues, but also help to learn from mistakes. Activities for managing possible risks in the ecosystem of the company should help to prepare countermeasures in advance. Company A implemented a plan-docheck-act cycle to show variances and develop countermeasures if needed. In comparison, company $\mathrm{C}$ conducts risk assessments and develops different scenarios of possible market evolutions. 
Leadership and commitment of the management team is necessary on the one hand to enhance the willingness to change within the organization, and on the other hand to support the implementation of change initiatives. Managers occupy an important position when it comes to BM changes. First, they need the experience and skills to identify changes but also have to be empowered to realize them within the organization. Second, when it comes to implementation, the commitment of the management team is essential as it is an important precondition for implementing directional shifts of the BM successfully. Company $\mathrm{F}$ highlighted that the most important capability in driving a BM change is the managers' gut feeling, which they see as an important part of leadership. Besides that, company L emphasized, that managers need the authorization and experience to develop further or change the BM.

Preparing the organizational structure allows companies to grow further as well as to recognize and pursue business opportunities much faster. Several examples were reported during the interviews. Company P referred about the change from a centralized to decentralized decision making. The establishment of groups responsible for the processes and tasks in their task pane and, therefore, also for possible changes, was reported by company $\mathrm{H}$. For the companies, these reorganizations support to increase the speed of actions because decisions are decentralized to where the information and competencies are available. Thus, established structures, processes and responsibilities need to be shifted.

\section{Discussion}

In our empirical study we investigated in several capabilities and properties in BM elements and in the entire BM to enable a flexible action and reaction, respectively. Some of our findings are already discussed in the literature on flexibility, changing the company but also in relation to BM changes, with the focus on predominantly highlighting single capabilities providing flexibility and enabling change. The purpose of our study was to empirically research on capabilities and properties in the context of BM changes. We especially shed light on an integrated view, where we do not point out single capabilities or properties enabling flexibility in the BM. Instead, we provide a picture of how a conscious preparation of the BM can be achieved. Furthermore, our goal was to empirically explain how single elements and the overall BM can be configured more flexible in order to deal with and change according to different internal and external needs. Capabilities and properties emerged in three out of four BM elements: 
- To enable flexibility in the value proposition, product modularity emerged as important. Existing literature discusses modularity as important precondition for adding or removing product lines (Almeida, Oliveira and Cruz, 2009, p. 31) or "facilitate flexible business models" in the development of a networked BM (Palo and Tähtinen, 2011, p. 377).

- In the value creation, the two factors establishing external partnerships and competence robustness are recently discussed in the BM literature: Cooperation is seen as a good way to enhance flexibility in the $\mathrm{BM}$ and reduces risks by sharing capacities (Mason and Mouzas, 2012, p. 1362). KPMG International (2006, p. 6) highlighted the importance of establishing " $a$ defendable position in the value chain" by concentrating on those activities where they are strongest. Versatility is defined as being "capable of dealing with many subjects" (Bahrami and Evans, 2005, p. 16p) that is also the sense of task and process versatility, the third factor in value creation.

- For the customer element, the necessity to sense and accumulate information on customer needs was identified as important to facilitate change. This can be attributed to the strong customer focus of the companies interviewed, experiencing the customer as a powerful driver of BM changes. This is discussed as important dynamic capability (Teece, 2007, p. 1322) and also as important capability in the BM literature (Dottore, 2009, p. 491; Mezger, 2013, p. 6).

- In the value capture, no capabilities and properties enabling BM flexibility were identified. We observed that costs, as the consequence of value creation, are often drivers of BM changes. Furthermore, the value capture needs to adapt as a result of changes in other BM elements.

Most of our capabilities identified enable flexibility of the overall BM. In our research, especially the factors determining the readiness for change were stressed by the companies interviewed. Change readiness includes the willingness to change, open communication and skilled people who are willing to recognize improvements, make changes and think out of the box. A particular significance is also attributed to the corporate culture that emerged as an important precondition to enable changes in the BM. In conjunction with BM changes, this was already discussed by Gassmann et al. (2014, p. 341) and described by Achtenhagen, Melin and Naldi (2013, p. 431) as a critical capability to exploit business opportunities. Companies also pointed out the importance of managing risks and learning as well as to prepare accordingly. Countermeasures taken by the companies interviewed include the monitoring and active planning of risks that may harm the business success. We also revealed the significance of leadership and the management commitment to changes or the preparation of the organization for fast 
decision-making, growth and implementation of changes. Managers play an important role because they need to recognize the necessity for change, drive this necessity and deal with associated risks (Charitou and Markides, 2003, p. 60; Demil and Lecocq, 2010, p. 241). Gassmann et al. (2014, p. 342) explained the importance of the management's commitment to change activities in the BM and to involve all employees in order to raise motivation and overcome barriers to change. The enhancement of flexibility due to a reduced complexity in organizational design was already argued by Bock, Opsahl, George and Gann (2012, p. 299). Furthermore, a study by Capgemini Consulting (2010, p. 12) revealed the significance of decentralization to align the focus of the BM on the customer. Based on these findings, the following implications for practitioners and research exist.

\section{Implications for practitioners}

For industry, the results postulate the necessity to understand one's BM conscientiously. This is helpful for preparing the BM accordingly to enable flexible action and reaction to changing needs. During the interviews we noticed that companies know their business models often quite well but have different understandings in terms of details and BM focus. However, most of them are not familiar with a system-oriented thinking of BM elements like the BM we proposed in this paper (see figure 1). The vast majority of participating companies changed and improved their BM in the course of strategic meetings and not by using any specific BM concept or tool. Moreover, we also observed that companies are very keen on understanding how to use $\mathrm{BM}$ concepts and tools to improve their BM so as to distinguish themselves from competitors, identify potential business opportunities and think out of the box. This requires the usage of the BM as strategic tool, where companies give their attention to single elements as well as their interrelationship and the alignment of the overall BM.

Our findings revealed that companies can enable and enhance BM flexibility by a conscious preparation of single BM elements and the overall BM. The identified properties and capabilities are helpful thereby. Furthermore, establishing these capabilities and properties in relation to factors driving BM changes helps developing those flexibility potentials that are required. Overall, this approach supports companies by providing an integrated view on important properties and capabilities that need to be developed to enable BM changes. Moreover, it provides companies the opportunity to identify and prepare for environmental developments early on and thus develop a competitive advantage. 


\section{Implications for research}

Our description of capabilities and properties enabling flexibility in the BM makes a contribution to the literature on BM changes, especially on the capabilities necessary for this purpose. The existing BM literature tends to focus on single capabilities and a detailed description thereof without assigning them to specific BM elements. Our research contributes with new insights by providing an integrated view about capabilities and properties that can be established in single BM elements in order to allow changing more flexible. This should be done by a conscious development of the properties and capabilities described above. However, as important as the flexibility in every single element we see the necessity for enlarging capabilities enabling the overall changeability of the BM. For future research, our results can be improved by identifying additional properties and capabilities in BM elements and the overall BM. This would help to establish a portfolio of suitable capabilities or properties that are helpful to handle changing conditions. Furthermore, we suggest conducting in-depth case studies in particular industries in order to understand industry specific characteristics in terms of factors driving and factors enabling changes in the BM.

\section{CONCLUSION}

The goal of our study was to determine factors that enable a flexible action or reaction according to changing needs. These factors should be identified in single BM elements as well as in the overall BM. Therefore, an exploratory, qualitative study with 20 participating high-technology companies was conducted. It was revealed that flexibility in the BM can be enabled in the form of capabilities or properties developed in both single BM elements and the overall BM in order to act or react to changing needs. Thus, our study provided an integrated view of specific capabilities and properties for changing the BM that was lacking in the previous literature, as presented in the introduction.

The results of this research work need to be viewed in the context of potential limitations. The qualitative research design chosen is, compared to quantitative studies, more of a subjective nature because our research does not rely on rigor calculations. To enhance the quality of our research, we used multiple sources and provided transparency in the research process. In spite of this, the use of multiple sources was limited to interview transcripts as primary data for the elaboration of results. Additional sources, like internal company documents, are only used as secondary data for plausibility checks. The reason for this was the non-availability of documents for most of the companies interviewed; annual reports and information on the number 
of employees, R\&D investments or turnover were also seldom available. Furthermore, the primary data are limited to information from a single interview partner in each company, which bears potentially the risk of a single informant bias. The results are also limited to companies operating in high-technology branches that feature specific characteristics. This reduces the generalizability of results for other industries. Furthermore, we concentrated on business units, divisions or companies in Austria. This is not a major limitation as all companies operate globally. Another limitation is the complexity of the field of study due to multiple interdependences, which raises the difficulty of discussing the topics with the interview partners. Owing to the complexity and diverse understanding of a BM, we had to invest a great deal of effort in analyzing the data and drawing conclusions on the meaning of the BM and on BM changeability. For the emerging literature on business model innovation, these restrictions should be overcome in order to emphasize the strategic importance of consciously rethinking the BM.

\section{References}

Almeida, F., Oliveira, J. \& Cruz, J. (2009). Paths to Innovate Business Models in an Economic Downturn. International Journal of Business and Management, 4(11), 29-37.

Bahrami, H. \& Evans, J. S. (2005). Super-Flexibility for Knowledge Enterprises. Berlin Heidelberg: Springer.

Birks, M. \& Mills, J. (2010). Grounded Theory: A Practical Guide. London: SAGE Publications Ltd.

Bock, A. J., Opsahl, T., George, G. \& Gann, D. M. (2012). The Effects of Culture and Structure on Strategic Flexibility during Business Model Innovation. Journal of Management Studies, 49(2), 279-462.

Bogner, A., Littig, B. \& Menz, W. (2009). Introduction: Expert Interviews - An Introduction to a New Methodological Debate. In A. Bogner, B. Littig \& W. Menz (Eds.), Interviewing Experts (pp. 1-13). London: Palgrave.

Brad, S. (2007). Comprehensive Innovation and its Implications on New HighTech Product Development. Informatica Economică, 42(2), 18-25.

Brehm, C. R. (2003). Organisatorische Flexibilität der Unternehmung: Bausteine eines erfolgreichen Wandels. Wiesbaden: DUV Gabler Edition Wissenschaft.

Capgemini Consulting. (2010). Geschäftsmodell-Innovation: Wer sich nicht neu erfindet, verschwindet. München: Capgemini Consulting.

Charitou, C. D. \& Markides, C. C. (2003). Responses to Disruptive Strategic Innovation. MIT Sloan Management Review, 44(2), 55-63.

Chesbrough, H. (2006). Open Business Models - How to Thrive in the New Innovation Landscape. Boston: Harvard Business School Press.

Chesbrough, H. (2010). Business Model Innovation: Opportunities and Barriers. Long Range Planning, 43(2-3), 354-363. 
Chesbrough, H. W. \& Rosenbloom, R. S. (2002). The role of the business model in capturing value from innovation: evidence from Xerox Corporation's technology spin-off companies. Industrial and Corporate Change, 11(3), 529-555.

De Toni, A. F. \& Tonchia, S. (2005). Definitions and linkages between operational and strategic flexibility. Omega, 33(6), 525-540.

Demil, B. \& Lecocq, X. (2010). Business Model Evolution: In Search of Dynamic Consistency. Long Range Planning, 43(2-3), 227-246.

Deschamps, J.-P. (2005). Different leadership skills for different innovation strategies. Strategy \& Leadership, 33(5), 31-38.

Dottore, A. G. (2009). Business model adaptation as a dynamic capability: a theoretical lens for observing practitioner behaviour. In: BLED 2009 Proceedings. eEnablement: Facilitating an Open, Effective and Representative eSociety (pp. 484-505). Retrieved from http://aisel.aisnet.org/bled2009/11/?utm_source=aisel.aisnet. org\%2Fbled2009\%2F11\&utm_medium=PDF\&utm_campaign= PDFCoverPages

Eisenhardt, K. M. (1989). Building Theories from Case Study Research. The Academy of Management Review, 14(4), 532-550.

EUROSTAT. (2014). Aggregations of manufacturing based on NACE Rev. 2. Retrieved from http://epp.eurostat.ec.europa.eu/cache/ITY_SDDS/Annexes/htec_esms_an3.pdf

Evans, J. S. (1991). Strategic Flexibility for High Technology Manoevres: A Conceptual Framework. Journal of Management Studies, 28(1), 69-89.

Ferguson, S., Siddiqi, A., Lewis, K. \& de Weck, O. L. (2007). Flexible and Reconfigurable Systems: Nomenclature and Review. Paper presented at The ASME 2007 International Design Engineering Technical Conferences \& Computers in Engineering Conference, Las Vegas, Nevada.

Flick, U. (2014). An Introduction to Qualitative Research. London: SAGE Publications Ltd.

Gassmann, O., Frankenberger, K. \& Csik, M. (2014). The Business Model Navigator: 55 Models That Will Revolutionise Your Business. Harlow: Pearson Education Limited.

Gioia, D. A., Corley, K. G. \& Hamilton, A. L. (2012). Seeking Qualitative Rigor in Inductive Research: Notes on the Gioia Methodology. Organizational Research Methods, 00(0), 1-17.

Golden, W. \& Powell, P. (2000). Towards a definition of flexibility: in search of the Holy Grail? Omega, 28(4), 373-384.

Hedman, J. \& Kalling, T. (2003). The business model concept: theoretical underpinnings and empirical illustrations. European Journal of Information Systems, 12(1), 49-59.

Helfat, C. E., Finkelstein, S., Mitchell, W., Peteraf, M. A., Singh, H., Teece, D. J. \& Winter, S. G. (2007). Dynamic Capabilities. Understanding Strategic Change in Organizations. Malden: Blackwell Publishing Ltd. 
KPMG International. (2006). Rethinking the business model. Retrieved from http://us.kpmg.com/microsite/FSLibraryDotCom/docs/Rethinking_the_ business_model.pdf

Krijnen, H. G. (1979). The Flexible Firm. Long Range Planning, 12(2), 63-75.

Magretta, J. (2002). Why Business Models Matter. Harvard Business Review, $80(5), 86-92$.

Mason, K. J. \& Mouzas, S. (2012). Flexible Business Models. European Journal of Marketing, 46(10), 1340-1367.

Massa, L. \& Tucci, C. L. (2013). Business Model Innovation. In: M. Dodgson, D. Gann \& N. Phillips (Eds.), The Oxford Handbook of Innovation Management. New York: Oxford University Press.

Maxwell, J. A. (2005). Qualitative Research Design: An interactive Approach. Thousand Oaks: SAGE Publications, Inc.

Mayring, P. (2010). Qualitative Inhaltsanalyse - Grundlagen und Techniken. Weinheim und Basel: Beltz Verlag.

Mezger, F. (2013, June). Business Model Innovation: Examining the Role of Capabilities and Environmental Contexts. Paper presented at EURAM 2013 Conference, Democratising Management, Galatasaray University, Istanbul, Turkey.

Mitchell, D. W. \& Coles, C. (2003). The ultimate competitive advantage of continuing business model innovation. Journal of Business Strategy, 24(5), 15-21.

Müller, C. (2014). Change of Business Models and the Role of the Business Ecosystem: Creating Flexibility in Business Models by Companies in HighTechnology Industries. Dissertation, Graz University of Technology.

Nair, S., Palacios, M. \& Tafur, J. (2011). Flexibility in airline business models with core competence as an indicator. In: Proceedings of the 15th Air Transport Research Society World Conference, Sydney. Air Transport Research Society. University of British Columbia.

Najmaei, A. (2011). Dynamic Business Model Innovation: An Analytical Archetype. In: International Proceedings of Economics Development and Research: vol 12. (pp. 165-171). Singapure: IACSIT Press.

Osterwalder, A. \& Pigneur, Y. (2010). Business Model Generation: A Handbook for Visionaries, Game Changers, and Challengers. Hoboken: John Wiley \& Sons, Inc.

Palo, T. \& Tähtinen, J. (2011). A network perspective on business models for emerging technology-based services. Journal of Business \& Industrial Marketing, 26(5), 377-388.

Romero, D. \& Molina, A. (2009). Value Co-creation and Co-innovation: Linking Networked Organisations and Customer Communities. In: L. M. Camarinha-Matos, I. Paraskakis \& H. Afsarmanesh (Eds.), Leveraging Knowledge for Innovation in Collaborative Networks, 10th IFIP WG 5.5 Working Conference on Virtual Enterprises, PRO-VE 2009: vol. 307 (pp. 401-412). Berlin Heidelberg: Springer. 
Schneider, S. \& Spieth, P. (2013). Business model innovation: Towards an integrated future research agenda. International Journal of Innovation Management, 17(1), 1-34.

Schuh, G., Friedli, T. \& Kurr, M. A. (2005). Kooperationsmanagement: Systematische Vorbereitung - Gezielter Auf- und Ausbau - Entscheidende Erfolgsfaktoren. Wien, München: Carl Hanser Verlag.

Styles, C. \& Goddard, J. (2004). Spinning the wheel of strategic innovation. Business Strategy Review, 15(2), 63-72.

Teece, D. J. (2007). Explicating Dynamic Capabilities: The Nature and Microfoundations of (Sustainable) Enterprise Performance. Strategic Management Journal, 28(13), 1319-1350.

Teece, D. J., Pisano, G. \& Shuen, A. (1997). Dynamic Capabilities and Strategic Management. Strategic Management Journal, 18(7), 509-533.

The Economist Intelligence Unit. (2005). Business 2010 - Embracing the challenge of change. Retrieved from http://graphics.eiu.com/files/ad_ pdfs/Business\%202010_Global_FINAL.pdf.

Wirtz, B. W. (2011). Business Model Management Design - Instrumente Erfolgsfaktoren von Geschäftsmodellen. Wiesbaden: Gabler Verlag.

Yin, R. K. (2009). Case Study Research: Design and Methods. Thousand Oaks: SAGE Publications.

Zakrzewska-Bielawska, A. (2010). High Technology Company - Concept, Nature, Characteristics. In: N. Mastorakis, V. Mladenov, A. Zaharim \& C. Aida Bulucea (Eds.), Proceedings of the 8th WSEAS International Conference on Management, Marketing and Finance, Recent Advances in Management, Marketing and Finances (pp. 93-98). Penang, Malaysia: WSEAS Press.

Zollenkop, M. (2006). Geschäftsmodellinnovation. Wiesbaden: Deutscher Universitäts-Verlag.

Zott, C. \& Amit, R. (2010). Business Model Design: An Activity System Perspective. Long Range Planning, 43(2-3), 216-226.

Zott, C., Amit, R. \& Massa, L. (2011). The Business Model: Recent Developments and Future Research. Journal of Management, 37(4), 1019-1042.

\section{Abstrakt (in Polish)}

Firmy stojq dziś w obliczu niestabilnych okoliczności, krótkich cyklów życia produktów oraz zmieniajqcych się oczekiwań klientów, w szczególności w obszarze zaawansowanej technologii. W takich warunkach, koncentrowanie się wyłącznie na innowacjach technologicznych i innowacjach produktu nie zapewni uzyskania przewagi konkurencyjnej. Dzisiaj firmy potrzebujq innowacyjnych modeli biznesowych, aby wyróżniać się od swoich konkurentów. Aby skutecznie zmienić modele biznesowe, firmy potrzebujq odpowiednich kompetencji. Tak więc celem tego badania jest określenie, w jaki sposób firmy moga przygotować model/e biznesowy/e by elastycznie reagować na zmiany środowiska, w którym działajq. $Z$ pomocq wybranego projektu badawczo-jakościowego, badamy firm działajqce $w$ branży zaawansowanych technologii. $W$ sumie 20 
firm wzięło udział w naszym badaniu. Wywiady zostały przeprowadzone z prezesami, wiceprezesami, menedżerami produktu lub innymi pracownikami na szczeblu kierowniczym, odpowiedzialnymi za rozwój modelu biznesowego. Badania wykazały, że firmy moga przygotować model biznesowy i jego elementy ex ante (na etapie planowania), rozwijajqc swoje możliwości w celu zwiększenia elastyczności modelu biznesowego. Możliwości te muszq zostać opracowane w odniesieniu do wielu wewnętrznych i zewnętrznych czynników powodujących te zmiany.

Słowa kluczowe: model biznesowy, innowacyjny model biznesu, zdolności do wprowadzania zmian, elastyczność, zaawansowane technologie.

\section{Biographical notes}

Christiana Mueller is a research and teaching assistant at the Institute of General Management and Organization. In her PhD thesis she focused on factors enabling flexibility in business models as well as the importance of the business ecosystem in the changeability of the business model. Furthermore, her research interests include innovation and technology management, strategic management and entrepreneurship.

Stefan Vorbach is a full professor at the Institute of General Management and Organization at Graz University of Technology. His research concentrates on topics including: innovation and technology management, particularly business model innovation, strategic management, entrepreneurship and intrapreneurship. 



\title{
Freemium business models as the foundation for growing an e-business venture: a multiple case study of industry leaders
}

\author{
Franziska Günzel-Jensen ${ }^{1}$, Anna B. Holm²
}

\begin{abstract}
In e-business freemium business models have become legitimate. However, current research provides little insight on how the free and premium offering should be employed to lead to growth and success in the long run. The presented research aims to fill this gap by investigating how the property 'free' was employed in young entrepreneurial ventures' business models in the initial life-cycle stages - opportunity recognition, market entry, and market exploitation. We find that various forms of freemium business models are employed through the initial life-cycle stages of a new venture for reasons of trial-and-error, learning, exploration, legitimization and resource acquisition. A freemium business model can also serve as a nascent business model, though without a sustainable monetization component, for finding a sustainable business model through a series of dynamic adjustments. With our findings we contribute to the business model literature in three ways: First, our empirical findings show the many-sidedness of the component 'free' in freemium business models. Free users are of importance for network building, exploration and exploitation and growth over time. Moreover, free users enable directly and indirectly further resource acquisition. Second, while previous literature has taken a static perspective, we contribute by illustrating the dynamic process of strategic business model design for growth. Finally, we introduce the concept of the nascent business model which is new to the literature.

Keywords: business model, case study, entrepreneurial venture, freemium, growth, IT, nascent business model.

\section{INTRODUCTION}

New businesses often start either from a market vision or from a technological capability. In both cases, the initial idea must be exploited with the aid of a

1 Assistant Professor, Aarhus University, Department of Management, Bartholins Allé 10, 8000 Aarhus C, Denmark, e-mail: frang@badm.au.dk.

2 Associate Professor, Aarhus University, Department of Management, Bartholins Allé 10, 8000 Aarhus C, Denmark, e-mail: annah@badm.au.dk.
\end{abstract}


business model (Chesbrough \& Rosenbloom, 2002) through value creation and capture activities (Teece, 2010; Zott, Amit, \& Massa, 2011). However, practice often shows that not every business model is designed and employed for the purpose of exploitation and growth from the beginning (Massa \& Tucci, 2013). The example of Google illustrates this perfectly. The firm started merely with a new technology for Internet search that was free and proved wildly successful with users due to its extraordinary utility, but with no idea whatsoever of how to make money from that. This was solved after some time when the firm invented yet another clever technology for selling space to advertisers on the users' search result web pages. The advertisers became Google's paying customers and the main source of revenues, and Google users enjoying the free service turned out to be a part of Google's value proposition (Kesting \& Günzel-Jensen, 2015). This realization led eventually to a successful business model, which was not envisioned from the beginning (Baden-Fuller \& Haefliger, 2013). After more than 15 years of existence, Google has become one of the most influential, profitable, and fastest growing companies in the world (Google Inc., 2013).

As in the case of Google, the logic of 'free' implies that ventures offer (parts of) their products or services for a price equalling zero, earning money elsewhere. Some authors claim that zero is the only reasonable price in the digital world (e.g. Andersen, 2009), while others point out that various young entrepreneurial companies have failed to convert 'free' into a sustainable business (Teece, 2010). Freemium has become one of the most prominent ways to earn money - giving a majority of users access to a basic version of the offering while charging few for a premium product or service (Teece, 2010). Some of the most commonly encountered freemium models are feature-limited and time-limited as well as hybrids hereof (Anderson, 2009). Although previous research has investigated various alternative revenue streams or more generic different patterns around freemium business models (McGrath, 2010; Osterwalder \& Pigneur, 2010), the value and implication of the free offering for the growth and profitability of young entrepreneurial ventures are largely unexplored although freemium business models are largely applied in the internet.

We approach the topic through the theoretical lens of the business model concept (Baden-Fuller \& Haefliger, 2013; Baden-Fuller \& Mangematin, 2013; Baden-Fuller \& Morgan, 2010) that can be referred to as a representation of the firm's realised strategy (Teece, 2010). Some research on business models consequently suggests that business models have properties that can translate into sustainable competitive advantage and superior financial performance (Amit \& Zott, 2001; Zott \& Amit, 2007) and that strategic business model design can influence high growth. Business models also 
change over time, with implications for company performance as well as growth potential (Teece, 2007; Voelpel, Leibold, \& Tekie, 2004). This research looks specifically at the property of 'free'in freemium business models and investigates how this has led to growth. More specifically, we investigate how young entrepreneurial ventures employed freemium business models (Osterwalder \& Pigneur, 2010) in the initial life-cycle stages - opportunity recognition, market entry, and market exploitation (George \& Bock, 2011). Following Bhide (2000) and Zott and Amit (2007) we define entrepreneurial firms as relatedly young organizations that have the potential of attaining significant size and profitability. For the purpose of this research, we conducted four case studies of successful e-business companies of this type.

The remainder of the paper is structured as follows: In the next section, we review business model and freemium literature and outline our research question. This leads to a description of our methodological approach, the data collection and analysis procedures. Following an account of the case studies, we then consider the relationship between the business model property 'free' and growth of an entrepreneurial venture. Finally, we suggest directions for further research and consider the implications of our study for entrepreneurs.

\section{Literature review}

Entrepreneurship researchers have pointed to growth as the crucial indicator for venture success and thus venture growth has become an important performance measure (Low \& MacMillan, 1988). Growth brings several advantages to an entrepreneurial firm: it increases its market power towards customers and suppliers, it expands its investment capacity in new products and technologies, and it raises the firm's visibility in markets to name only a few (ibid.). Therefore, growth is considered an important goal for new entrepreneurial ventures. High-growth firms are also of interest to other stakeholders because of their contribution to job creation and innovation (Achtenhagen, Naldi, \& Melin, 2010). A wide range of factors exists that affect the growth of firms ranging from the individual to organizational to environment level (Baum, Locke, \& Smith, 2001); however, the process of how various factors impact growth remains unexplored (Davidsson, Achtenhagen, \& Naldi, 2005; Leitch, Hill, \& Neergaard, 2010), and one of those poorly researched factors is the firm's business model.

\section{Business model}

In innovation management and strategy research the business model concept is often referred to as core business processes associated with value 
proposition, creation, delivery and capture (Günzel \& Holm, 2013; Holm, Günzel, \& Ulhøi, 2013; Johnson, Christensen, \& Kagermann, 2008; McGrath, 2010; Teece, 2010). Although business models have been integral to trading and economic behaviour since pre-classical times (Teece, 2010), the business model concept became prevalent with the advent of the Internet in the mid-1990s, and it has been gathering momentum since then (Zott et al., 2011). Recent advances in information and communication technologies have allowed the development of new ways to create, deliver and capture value, which have offered scope for the creation of unconventional exchange mechanisms and transaction architectures (Amit \& Zott, 2001) and accentuated the possibilities for the design of new boundary-spanning organizational forms (Daft \& Lewin, 1993; Dunbar \& Starbuck, 2006).

Indeed, these developments have opened new horizons for the design of business models by enabling firms fundamentally to change the way they organize and engage in economic exchanges, both within and across firm and industry boundaries (Mendelson, 2000). The freemium business model, where basic products or services are offered for a price of zero, has become an extremely popular model. The model became dominant primarily within Internet companies and companies that develop applications for smartphones. For example, 98\% of Google Play Store revenue and 95\% of Apple's app Store revenue come from freemium applications (Froberg, 2015).

The freemium business model for e-business is best described using the typology proposed by Baden-Fuller, Haefliger and Mangematin (Baden-Fuller \& Haefliger, 2013; Baden-Fuller \& Mangematin, 2013) based on the following four dimensions: 1) customer identification, 2) customer engagement, 3) value delivery, and 4) monetization. Following this typology, for freemium e-business models we can define the four dimensions as follows. First, the logic of freemium implies that a part of the product is free for almost everyone often attracting a large number of users who do not pay. In sustainable business models, payment is made by others, i.e. customers for a premium service. Those hybrid business models that are based on free offerings (see e.g. McGrath, 2010), however, rely on more than one value proposition and different customer groups. Second, the free offerings are often designed for a wide range of users, i.e. mass market, and are typically standardized. Differently put, the freemium business model relies mainly on "one-size-fitsall" goods or services, or as described by Baden-Fuller and Haefliger (2013), on the value produced by "one-size-fits-all" bus system. Third, the value offering is delivered digitally, i.e. via the Internet or other digital connection onto an ICT device with a specific platform, and through a network of intermediaries, e.g. internet and cloud service providers, online distributors and other various intermediaries. Fourth, the free offering to mass customers 
does not generate any revenue streams per definition, and only inflicts costs. As mentioned earlier, monetization, or value capture is achieved by going beyond the traditional buyer-supplier relationship, and moving onto hybrid business models or replacing the free offering. Thus, a freemium business model and the companies' offerings need to be further developed, adjusted and transformed over time.

While alternative revenue streams or more generic and different patterns around freemium business models have been discussed (e.g. McGrath, 2010) the role of free users for growth has only received limited attention so far. However, 'free' seems often to be the foundation for value capture opportunities and growth in the future, such as the case of many successful e-business ventures, e.g. Facebook, Google, Linkedln, and many others.

\section{Growth, network effects and 'free' users}

Assessing the role of a freemium business model for company's growth entails analysis of the relations between the processes of opportunity identification and new venture creation and its sense-making and articulation through the business model over time. While existing studies manage to give an answer to the question of how different antecedents influence growth, they largely fail to explain underlying processes. Research so far has pointed to the following criteria that enable a company to apply a freemium business model to grow and sustain: network effects and conversion rate (Pujol, 2010).

Many freemium providers run their businesses in markets with direct network effects (Pujol, 2010). In these markets, free users are of immense value as they are the foundation for network effects. As the total number of users grow the perceived utility of social network-based applications increases due to the direct network externalities (Clements, 2004). In the presence of network externalities, a product becomes more attractive as the total number of users increases (Conner, 1995) and such attractiveness often translates into a price premium (Salganik, Dodds, \& Watts, 2006). Previous research has shown the positive impact of direct network externalities on the diffusion of digital products in various markets such as Internet instant messaging service (Wang, Hsu \& Fang, 2004), peer-to-peer file sharing service (Strahilevitz, 2003), and mobile network service (Birke \& Swann, 2006).

In multiplayer online games there is evidence that certain characteristics of a user's social network are linked with their conversion (Sylvester \& Rand, 2014). Conversion is the percentage of free users that upgrade to premium users. Besides advertisement premium user fees are often a main revenue stream for ventures employing a freemium business model. In their study Sylvester and Rand (2014) point out that the number of friends with a 
premium account and the time since the last friend converted has been a strong influence on a user's own conversion. Furthermore, researchers have pointed out that strong network effects make it harder for competitors to establish themselves in the market (Eisenmann, Parker \& Van Alstyne, 2011).

With a few exceptions (Andries, Van Looy, Lecocq, \& Debackere, 2008; Cavalcante, Kesting, \& Ulhøi, 2011; Sosna, Trevinyo-Rodriguez, \& Velamuri, 2010; Vaccaro \& Cohn, 2004), most literature on business models in general and ventures employing a freemium business model have taken a static perspective, implicitly assuming them to remain stable over time. However, as Brokaw (1993) found, a large fraction of firms change the initial market offering, the network, and the value creation logic and thus their business model. Additionally, studies show that it is this change that is crucial to success and survival of new ventures (Bamford, Dean, \& McDougall, 2000; Kazanjian \& Drazin, 1990; Reynolds \& Miller, 1992). While reasons for business model adaptation are researched to a certain extent (e.g. de Reuver, Bouwman, \& Maclnnes, 2009), the process and structure of how business models transition through the initial life-cycle phases - opportunity recognition, market entry, and market exploitation - remain under-investigated (George \& Bock, 2011). Additionally, we lack an understanding of how the business model component 'free' enables growth in these periods and how it is developed to ensure growth and sustainability. Therefore, first this study looks in depth as to how a young entrepreneurial venture's business model transforms from one stage of business development to another, and second at the role of the 'free' offering in those transformations.

The three life-cycle stages of a firm are characterised as follows, the opportunity recognition stage includes opportunity identification and selection as well as opportunity development. According to Ardichvili, Cardozo and Ray (2003) this phase is especially about the careful investigation of and sensitivity to market needs as well as the entrepreneur's ability to spot suboptimal deployment of resources. Additionally, opportunity development involves entrepreneurs' creative work for example in form of innovative orchestration of resources. In the market entry phase firms define their strategy and market positioning (Gans \&Stern, 2003) as well as their place in the value chain. Start-ups still adjust their market offering in order to find a product-market fit. In the market exploitation start-ups move from exploration to exploitation. We follow Levinthal and March (1993: 105) who define exploitation as the 'use and development of things already known' exhibiting returns that are positive, proximate and predictable.

This article sets out to explore the development undergone by young entrepreneurial e-business ventures' freemium business models and its 
interplay with business growth employing an inductive approach to this currently under-researched phenomenon. As the area is vaguely researched, no specific hypotheses or propositions are suggested at this stage of the article, but they emerge as evidence and are analysed and discussed.

\section{Method}

We considered a case study appropriate as a research method since little is known about the relationship between growth and specific business model design (Eisenhardt, 1989). Therefore, we employed the multiple explanatory case study design for our investigation (Yin, 2003). Due to the purpose of the study, we adopted a purposeful sampling strategy (Patton, 2002) which permits studying the phenomenon of 'free' in detail, as well as gaining insight and in-depth understanding of the freemium business model (Eisenhardt \& Graebner, 2007). This sampling strategy was considered important to make a theoretical contribution through the study of cases in which the phenomena are best brought out or illustrated most completely (Ridder, Hoon, \& McCandless, 2009). Following this logic, we derived four cases representing Internet industry leaders within the fields of music, data storage, human resources, and event organization. We selected the cases according to the following criteria:

1) Age: A company should be more than five years old and must have launched their product and established itself in the market successfully. This will enable us to track the business model development and how 'free' impacted growth in the opportunity recognition, market entry, and market exploitation phase.

2) Online offering: To acknowledge specifics of online vs. offline offering, this study focuses only on companies that offer there products and services online.

3) Growth rate: When growth is conceived as a process there is little doubt that it is preferable to have several indicators of growth and that they need to be assessed at several different points in time (Davidsson et al., 2005). The company must have experienced a fast increase in users and employees. For employees more than 20 need to have joined within 5 years (Bosma, Jones, Autio, \& Levie, 2007 ) of the launch of the first version of the product.

4) Ownership: It is important with respect to legitimacy and resource acquisition possibilities that the companies are new ventures, not spinoffs of incumbents.

5) Pricing: In line with our research purpose, the company must offer a substantial part of their products or services to their users for free. 


\section{Profile of the case firms}

Our first case, Spotify, is a commercial music streaming service providing Digital Rights Management-protected music from various record labels like Sony, Warner Music Group and Universal. Founded in 2006, it has been launched in October 2008 by the Swedish start-up Spotify AB. Spotify is available in 35 nations with different versions of a freemium business model. By March 2013, Spotify has grown to six million paying customers globally and 24 million active users in total. Spotify has more than 800 employees and public reports value Spotify at more than US\$ 3 billion, based on an estimated US\$ 188 million raised in funding.

Our second case, Eventbrite, was founded in 2006, and is an international website that allows event organizers to plan and set up ticket sales and promote events of any size and publicize them across Facebook, Twitter and other social-networking tools directly from the site's interface. Eventbrite originally targeted the "odd job" of smaller events, but has grown strongly and now caters also for massive music shows. Eventbrite is using the so-called "long-tail" business model (Osterwalder \& Pigneur, 2010) and generates revenue by charging a $2.5 \%$ fee on the ticket price, plus US\$ 0.99 for every ticket sold. The business does not charge a fee for events that are free which is the case for most of the events posted on Eventbrite (approx. $70 \%$ of all events). Until mid-2013 Eventbrite received a total funding of US\$140 million and had 329 employees by the end of the same year. In September 2013, Eventbrite announced that they had processed US\$ 2 billion in gross ticket sales since they were founded.

Our third case, LinkedIn is a social network site service that provides a possibility to create, manage and share a professional identity online, build and engage with professional networks, access shared knowledge and insights, and find business opportunities. The company was founded in 2002. The company broke even in 2006, and since then its revenue practically doubled every year. More than $40 \%$ of revenues in 2012 came from recruiters, who paid to access profiles, communicate with users and for other services. In May 2011 LinkedIn closed its initial public offering, and in November 2011, its follow-on offering. LinkedIn was then valued at US\$ 1 billion. By 2012 LinkedIn had over 200 million individual, predominantly, free members.

Our fourth case, Box Inc. (formerly Box.net) is an online file sharing and Cloud content management service, which saves and stores the information uploaded by the customer to their website. It was founded in 2005 and secured US\$368.6 million of funding until today. Box offers three user account types: enterprise, business and personal. Depending on the type of account, Box has features such as storage, custom branding and administrative controls. There are also third party integrations with applications like Google 
apps, Gmail, NetSuite and Salesforce. Individuals can sign up and use limited amount of services for free though with some restrictions to the amount of storage space and file size.

For an overview of important key information and indicators of the four cases please see Appendix 1.

\section{Data}

To secure the rigor of our study we collected data from multiple sources (Hancock \& Algozzine, 2006) (for an overview of the data, please see table 1). Firstly, we collected various documentary evidence (Yin, 2003) such as annual reports, newspaper articles, press releases, white papers, as well as other secondary data such as presentations, publically available interviews with case company managers and textual data from social network sites such as Linkedln and Twitter. We collected the data for all the years of the company's existence until 2013. Secondly, we visited headquarters of two case companies - Box.com and Linkedln conducting on-site in-depth interviews. We have also conducted a number of in-depth interviews with key employees from the two other case companies via Skype. All interviews focused on the case companies' business model development from opportunity recognition to market exploitation as well as the purpose and the consequences of free offerings. The interviews lasted between 30 minutes and 1.5 hours. All interviews were digitally recorded and fully transcribed, and together with the rest of the data exported to NVivo 10 software for further analysis.

Table 1. Data sources

\begin{tabular}{llll}
\hline Data type & Sources & Data format & Length \\
\hline $\begin{array}{l}\text { In depth face-to- } \\
\text { face semi-struc- } \\
\text { tured interviews }\end{array}$ & $\begin{array}{l}\text { Long-term employees at } \\
\text { the executive level }\end{array}$ & $\begin{array}{l}\text { Digital sound } \\
\text { recordings and } \\
\text { transcriptions }\end{array}$ & $\begin{array}{l}6 \text { recorded interviews } \\
\text { of approx. 20,600 } \\
\text { words }\end{array}$ \\
$\begin{array}{l}\text { Internal archival } \\
\text { data }\end{array}$ & $\begin{array}{l}\text { Press releases, white } \\
\text { papers, internal reports } \\
\text { and presentations, video } \\
\text { archives, social media }\end{array}$ & $\begin{array}{l}\text { Electronic files and } \\
\text { recorded videos }\end{array}$ & $\begin{array}{l}351 \text { documents of } \\
\text { approx. 532,880 words }\end{array}$ \\
$\begin{array}{l}\text { External archival } \\
\text { data }\end{array}$ & $\begin{array}{l}\text { Newspaper articles, general } \\
\text { and scientific articles }\end{array}$ & Electronic files & $\begin{array}{l}321 \text { documents of } \\
\text { approx. 186,000 words }\end{array}$ \\
\hline
\end{tabular}

\section{Data analysis}

In order to establish the relationship between the business model configuration, including the 'free' component, and company growth the data 
were analysed in two rounds. The first round followed a three step process: data reduction, data display and conclusion drawing (Miles, Huberman, \& Saldana, 2014). It started with reducing the data to the relevant information corresponding to the business model components as they were laid down by Baden-Fuller and Haefliger (2013). Simultaneously, we were assigning each data piece a timestamp code corresponding to the calendar year and the month of the reported event, situation, or other development. We then generated data matrices for each calendar year of the company with the data pieces corresponding to the business model framework as it is laid down by Baden-Fuller and Haefliger (2013). Additionally, we reviewed our data and identified gaps and missing pieces of information for each year, and collected further documentary information to fill in the gaps.

We proceeded with data analysis by making summaries for each business model component and calendar year in the matrices and also by analysing inductively and producing open codes. The summaries were further analyzed and preliminary conclusions drawn. The matrices were consequently reduced to represent summaries and conclusions for each calendar year of operations and each business model component of our case companies. As the aim was to understand the interplay of 'free' and growth we were seeking for information on how the free offering formed over time and how its integration into the design of the business models supported growth of the case companies.

We further analysed the matrices and then grouped them for each case company in three sets, corresponding to the periods of the case companies' life-cycle stages - opportunity recognition, market entry, and market exploitation (George \& Bock, 2011) thus building representations of business model evolution. That was followed by the second round of analysis, where we were looking at various links, explanations and relationships between the business models' configurations and the growth producing a number of open codes. Those codes were consequently grouped in categories and themes, following the logic of inductive, analytic and interpretive inquiry processes (Lincoln \& Guba, 1990).

Finally, we conducted in-depth case analyses highlighting the development of business models and the role of 'free' in the individual cases through the initial life-cycle phases as well as the interplay of the freemium business model and growth of the companies. Afterwards we compared the findings of the individual cases across our four cases. We will highlight in the following the similarities which were recurrent in all four cases across the three life-cycle phases. 


\section{Findings}

All four cases present high growth entrepreneurial ventures' in term of users, customers and revenue over the three distinct stages of development - opportunity recognition, market entry, and market exploitation. Despite their success (and critiques from various sides) all companies kept on to their free market offering, most of them expanding and innovating it over the years. In this way they differentiate themselves clearly from companies that use 'free' for beta-testing or short-term advertising. The results that we present in the following shed further light on the importance of their free offering, its development and its impact on growth. For a summary of how the business models of the various companies developed please see Table 2. Table 3 provides an overview of how free users and the freemium offering influenced growth.

In the opportunity recognition stage all four case companies employed a nascent business model and focused on building up the product in line with customer requirements in order to reach a product-market fit. Nascent business models are business models without a sustainable monetization component, for finding a new sustainable business model through a series of dynamic adjustments. The companies at this early stage only focused on early adaptors and often access was restricted to this group. With this group the companies build up a very strong network of evangelists. The companies experienced that these users were willing to share their experiences with them, thus, being involved in value configuration and development of the market offering. Although Spotify and Eventbrite do not have any obvious network externalities, they made a tremendous effort to add a social network aspect that does. With the integration of social media such as Twitter and Facebook, both companies enable users to share music and events with friends.

Free users provide valuable information about emerging trends, new solutions that can be developed and implemented to improve either the free service, the premium service or both. The need to further develop the products and advance technological solutions is facilitated by attracting substantial external capital. For example, according to press releases and newspaper reports in 2006 - the second year of operations - Box counted 500,000 registered users and received $\$ 1.5$ million in A-series funding from Draper Fisher Jurvetson. Just one year later, Box raised a Series B round of \$6 million. Free users were from very early on in the company's development understood as important to acquire resources.

After creating a market offering that is highly relevant for evangelists the companies focused on volume and user growth in the market entry phase. The final version of the business model of the opportunity recognition stage 
was then scaled up. Scaling in terms of users was achieved through first, word-to-mouth marketing of existing free users and second, heavy use of web analytics to understand their free users.

With regards to the first issue, all case companies experienced that if their offering provides value to free users, then existing users would likely assist spreading of the software/application through word-to-mouth promotion. In the market entry phase this would lead to a fast growth of free users and the platform as the following quote illustrates:

"The free events and the free attendees are of huge value to our company. People are adding wonderful inventory to our platform; people who are telling their friends about us when they've had positive experience with us. So it is a wonderful way for us to build quality inventory, to reach new attendees, and also to a certain degree to expose people to the product." (interview with a representative of case \# 2)

With regards to the second issue, web analytics became of major importance for all companies as a tool to understand users and customers. The technology provided ample data on user online behaviour and preferences, and allowed the companies to adjust their value propositions to serve their customers. Having big numbers of product users, permitted the companies to figure out which features potential customers would be willing to pay for, and also to make a segmentation of different customer groups. For example, LinkedIn monitored the behaviour of its users on the online platform, and based on the observations they assigned the members to three categories of customers: relationship managers, contactors, and networkers (Piskorski, 2007). Companies in this stage clearly separated free from premium offering. The use of free offering at this stage is of a relational nature, as companies focused not only on growing user numbers, but also seriously processed information in order to identify and increase numbers of paying customers. Moreover, through the growth in users the company could build up a brand and get a lot of awareness from the media. This expansion was matched with a growth in number of employees, external finance etc.

At this stage, the case companies actively turn to additional free offerings to maintain a high degree of user and customer satisfaction. For example, according to social media and press releases, Box regularly added additional free storage to its non-paying users, and to a greater extent, to existing subscribers. In 2010 it launched a free app for iPads and iPhones based on Apple's iOS operating system. The free app connected online document repository to iOS devices and allowed subscription customers (both paying and free) to browse and preview their files online. A free subscription gave one gigabyte of storage, and as the iPad and iPhone apps were also free, some users considered it worth signing up just for the easy transfer of files 
between their mobile devices and computers. Another good example comes from Spotify. Initially, the company limited free users as to which platforms they could use and as to how many hours they could enjoy the streaming for free. In 2014 the limit was removed, and users were allowed to download and use Spotify music streaming on their mobile or tablet absolutely free of charge. This also shows that free users were not taken for granted, but value was added for them throughout to retain them.

In the market exploitation phase the companies changed their focus to performance and establishing themselves as industry leaders. They started building complementary products (in-house and in cooperation) to retain and lock-in customers. These complementary products are often offered again for free, but their offering becomes more complex and more suitable for the $\mathrm{B} 2 \mathrm{~B}$ context. Free users appear to play a significant role in the transition from a B2C to B2B as they often were the door opener towards potential B2B customers. On the one hand, satisfied users would bring the product into the company on their own:

"In many cases someone signs up for free and then, over time they like (our service) so much that they will bring it into their work life and they will say 'hey, we could you use this for our team, our projects, our company' and then it starts spreading throughout the organization." (interview with a representative of case \# 4)

On the other hand, our case companies would approach free users actively and involve them in a conversation if their offering (which the user has been using only privately so far) would also be interesting for the company they work for as the following quote shows:

"It's a great way to get into businesses. It gives us a lead, right? We of course track everything... and when we see that somebody signs up with a Coca Cola address and they start sharing with other Coca Cola users, we can see the network effect. Then suddenly we can call them up and say: 'Oh, I see you are using our product. Have you thought about upgrading to the business account?' Right? It's a great way for us to get leads. Once you get those hot leads, then you have to go and start talking to the $\mathrm{ClO}$ s and the business decision-makers. 'Cause a lot of times people who sign up online might be low level individuals, or individual contributors, and not managers. But they can still make introductions to us. So, of course, our sales team is being trained to go and work... you know." (interview with a representative of case \# 4).

Furthermore, internationalization becomes a main priority for the companies. They expand their physical presence internationally and localize the product in the market entry phase. Often companies add headquarters in other destinations to gain more local knowledge and easier access to local channels if needed. 
Table 2. Business model elements' development in the opportunity recognition, market entry, and market exploitation stage

\begin{tabular}{|c|c|c|c|}
\hline & $\begin{array}{l}\text { Opportunity } \\
\text { recognition }\end{array}$ & Market entry & Market exploitation \\
\hline $\begin{array}{l}\text { Value proposition } \\
\text { development }\end{array}$ & $\begin{array}{l}\text { Create a unique } \\
\text { value proposition } \\
\text { (i.e. different from } \\
\text { competitors) }\end{array}$ & $\begin{array}{l}\text { Adjust value } \\
\text { proposition to user } \\
\text { and customer needs }\end{array}$ & $\begin{array}{l}\text { Review value proposition; } \\
\text { launch complementary } \\
\text { offerings explore new } \\
\text { offerings for new } \\
\text { segments, e.g. B2B market }\end{array}$ \\
\hline $\begin{array}{l}\text { Customer } \\
\text { identification }\end{array}$ & $\begin{array}{l}\text { Mass market } \\
\text { consisting mainly of } \\
\text { individuals }\end{array}$ & $\begin{array}{l}\text { Mass market, } \\
\text { small and medium } \\
\text { enterprises }\end{array}$ & $\begin{array}{l}\text { Mass market, small and } \\
\text { medium enterprises, large } \\
\text { companies }\end{array}$ \\
\hline $\begin{array}{l}\text { Customer } \\
\text { engagement }\end{array}$ & $\begin{array}{l}\text { Interaction with early } \\
\text { adaptors; attraction } \\
\text { of maximum possible } \\
\text { users }\end{array}$ & $\begin{array}{l}\text { Cooperation on } \\
\text { product development, } \\
\text { increased customer } \\
\text { outreach through } \\
\text { third-party products }\end{array}$ & $\begin{array}{l}\text { Long-term agreements } \\
\text { with paying customers }\end{array}$ \\
\hline Value delivery & $\begin{array}{l}\text { Directly through own } \\
\text { channels }\end{array}$ & $\begin{array}{l}\text { Directly and through } \\
\text { own channels and } \\
\text { through popular } \\
\text { online third-party } \\
\text { applications }\end{array}$ & $\begin{array}{l}\text { Directly through own } \\
\text { channels, through } \\
\text { popular third-party online } \\
\text { applications, and through } \\
\text { bundling with digital and } \\
\text { physical products }\end{array}$ \\
\hline Monetization & $\begin{array}{l}\text { Large numbers of free } \\
\text { users (negative) }\end{array}$ & $\begin{array}{l}\text { Large numbers of } \\
\text { free users (negative), } \\
\text { revenues from } \\
\text { growing number of } \\
\text { paying customers } \\
\text { (positive) }\end{array}$ & $\begin{array}{l}\text { Large numbers of free } \\
\text { users (negative), revenues } \\
\text { from growing number } \\
\text { of paying customers and } \\
\text { large companies (positive) }\end{array}$ \\
\hline $\begin{array}{l}\text { Business model } \\
\text { components that } \\
\text { are subject to } \\
\text { change }\end{array}$ & $\begin{array}{l}\text { Focus on value } \\
\text { configuration, } \\
\text { customer } \\
\text { identification and } \\
\text { value chain linkages }\end{array}$ & $\begin{array}{l}\text { Focus on customer } \\
\text { engagement; search } \\
\text { for sustainable } \\
\text { revenue model, i.e., } \\
\text { monetization }\end{array}$ & $\begin{array}{l}\text { Optimize revenue model } \\
\text { and secure value capture. }\end{array}$ \\
\hline
\end{tabular}

Table 3. Entrepreneurial and strategic orientation in the opportunity recognition, market entry, and market exploitation stage

\begin{tabular}{|c|c|c|c|}
\hline & $\begin{array}{l}\text { Opportunity } \\
\text { recognition }\end{array}$ & Market entry & Market exploitation \\
\hline Foci & $\begin{array}{l}\text { Build product; } \\
\text { understand customer; } \\
\text { find product-market } \\
\text { fit }\end{array}$ & $\begin{array}{l}\text { Increase market } \\
\text { penetration, gain } \\
\text { market share, find } \\
\text { new (i.e. paying) } \\
\text { customer segments }\end{array}$ & $\begin{array}{l}\text { Product adaptation, } \\
\text { grow product } \\
\text { portfolio, establish } \\
\text { company as industry } \\
\text { leader, secure } \\
\text { performance, lock-in } \\
\text { customers }\end{array}$ \\
\hline Role of free offering & Attract early adaptors & $\begin{array}{l}\text { Attract as many } \\
\text { consumers as possible } \\
\text { (network effects); } \\
\text { build product/firm } \\
\text { awareness }\end{array}$ & $\begin{array}{l}\text { Attract mass market } \\
\text { consumers; retain } \\
\text { customers }\end{array}$ \\
\hline
\end{tabular}


Role of free users

Basis for trial-anderror learning and exploration

Role of paying customer Growth to-pay Growth through
Explore willingnessattracting external capital

Business model ideation and creation

Business model change (Calvacante et al. 2011; Günzel, 2011) Internationalization

Unintended organic
Basis for R\&D, legitimization of the market offering and company, important resource for further resource acquisition Gain recognition and legitimize business Growth through increasing user numbers, attracting external capital, hiring employees Business model validation
Access to paying customers (especially companies)

\section{Secure revenue} streams Growth through value extension and new customer acquisition; growth through partnerships Scaling of business model

Targeted based on organic adaptation

\section{DISCUSSION}

With this research we add to the evolutionary view in the business model literature. Scholars in this stream of business model literature focus "on the role of experimentation in the generation and change of business models" (Martins, Rindova and Greenbaum, 2015: 101). We find that the business model component 'free' plays a central role for experimentation and learning and conclude that the business model component 'free' is employed in various ways throughout the initial life-cycle stages of a new venture for reasons of trial-and-error, exploration, adjustment, legitimization and resource acquisition.

The observed variations in business model configuration also reflect the strategic objectives of the new entrepreneurial firms at different stages of growth, and can be viewed as the representation of the realised strategy (Casadesus-Masanell and Ricart, 2010). While the case companies were building up their presence in the marketplace trying to conquer a market share that would permit further growth, their business models were still in some early stage of development, as they missed the main component, i.e. monetisation (Baden-Fuller and Haefliger, 2013), to become sustainable. This approach to business model development is closely related to the discovery driven approach of strategizing and business model configuration as it is laid out by McGrath (2010). Moreover, the collected evidence suggests that there might be different stages in business model development from the early-birth to maturity, where the business model undergoes a series of major transformations. While the choice of free offering was a management decision, the consequences of that choice can be seen in the next-stage 
business model configuration, i.e. inline with the view on business models emphasised by Casadesus-Masanell and Ricart (2010).

In our cases the free business model served as a nascent business model, a business model without a sustainable monetization component, for finding a sustainable business model through a series of dynamic adjustments. A nascent business model has temporary character and is used for exploration to move from idea to practice. The nascent business model is employed in a period of intensive learning and experimentation. Experimentation refers to 1) performing practices that are new to the market e.g. collaborating with new partners, 2) exploring the willingness to pay of customers and 3) researching the possibilities to use technology to respond to market needs. Learning means 1 ) acquiring new insights into customer needs, 2) understanding how to differentiate the market offering from that of competitors, and 3 ) realizing potential for collaboration with other start-ups and stakeholders. The later is of utmost importance to overcome financial shortages.

At later stages of venture creation, the component 'free' is maintained for the purpose of market development or penetration. Here 'free' plays an important role to attract and engage as many consumers as possible and thereby take advantage of network effects. Furthermore, the companies still learn and adjust their value proposition. Especially, companies continuously adapt which parts of a product should be free and which should belong to a premium offer. These findings are in line with Sosna et al. (2010) who state that during the first years of the company initial exploration of the "best" business model takes place followed by the exploitation phase when a viable business model emerges and continuous trial and error still take place, but without changing the core of the company. In this paper we show the relevance of the component 'free' to enable the experimentation and learning that Sosna et al. (2010) point to.

In recent years, business model design has been described as a performance driver of entrepreneurial firms (Amit \& Zott, 2001). In their 2007 paper, Zott and Amit (2007) identify two critical dimensions of business model design, which they denote as "efficiency-centered" and "novelty-centered", which is similar to the strategic management thought of pursuing cost-based and differentiation strategies of incumbent firms. However, little knowledge has ever since been gained on how business models can be designed and developed over time to drive performance and growth of an entrepreneurial firm. Here this paper's underlying approach and its presented insights can contribute. Business model design for performance and growth is not an issue that can be addressed in a static manner. As pointed out in previous research (Bamford et al., 2000; Kazanjian \& Drazin, 1990; Reynolds \& Miller, 1992), business models, especially of young entrepreneurial ventures, need 
adjustment and refinement over time and thus longitudinal research studies are also needed to investigate the phenomena holistically. This research makes a first attempt using a wide range of empirical data to provide more in-depth knowledge how business models can change to be a performance driver of the company.

With this research we also responded to a call in recent entrepreneurship literature to focus rather on "how" firms develop and grow than on "how much" (Davidsson, et al., 2005; Leitch, et al., 2010; McKelvie \& Wiklund, 2010). As suggested by McKelvie and Wiklund (2010) we have made use of in-depth methods to better capture the process that leads to growth and thereby generate novel insights. One interesting finding of our study is that growth comes before profitability when successfully applying freemium business models. This is in contrast to recent findings in the growth literature that indicate that firms that grow successfully do so by first securing profitability, and then going for growth (Davidsson et al., 2005). That is why researchers have called for caution against a universal and uncritical growth ideology. As it appears, firms that grow at low profitability often end up in the undesirable state of low growth and low profits instead. Here the process of business model development might shed some more nuanced light on the phenomena. The four cases, that have been investigated in this study, are all based on strong network effects. They employed a growth-beforeprofitability strategy and became profitable in the long run. Therefore, the business model, bridging internal development and opportunity recognition in an entrepreneurial setting (George \& Bock, 2011), might be an interesting unit of analysis when studying growth as it can depict the complexity of the phenomenon growth.

\section{CONCLUSION}

With this study we contribute to this on-going dialogue of researchers and practitioners. Our findings show that the component 'free' in business models serves different purposes through the initial life-cycle stages of a young entrepreneurial venture: learning, exploration, adjustment, access, growth and legitimization. Free business models serve in the opportunity recognition stage as a nascent business model for finding a new sustainable business model through a serious of dynamic adjustments.

The free offering being initially the value produced by the "one-size-fitsall" or bus system, as described by Baden-Fuller and Haefliger (2013) brings the firm a growing pool of users, who despite the costs become a valuable strategic resource for further business model development. At a later stage, the free offering was consistently used as a customer engagement element 
of the BM, and also to promote new initiatives and maintain customer loyalty to retain the existing user and customer base. Moreover, 'free' enables new ventures to identify and segment customer groups that can potentially become paying customers. That also leads to new specifically targeted offerings, i.e. adding new customer engagement elements to the business model. Those are tailored for specific customer groups, i.e. the "taxi" service and lead to enhanced chances for monetization. Value capture is then secured by relationship, and moving onto hybrid business models or replacing the free offering with a targeted value propositions for specific groups of paying customers. In this way, the 'free' element is organically integrated in business model creation and further development until a business model becomes sustainable. At later stages, the 'free' component can be maintained for purposes of further market development or penetration.

These findings contribute to the business model literature as to the ongoing discussion about the development of business models over time and their impact on growth and performance. For the first time. we inform the literature in-depth about the many-sidedness of the component 'free' in business models and how it builds the foundation for value capture opportunities.

\section{Implications for research}

Several new research questions emerged during the analysis of the data from this multiple case study. First, we call for more research on freemium business models as it is a widely applied business model in practice but hardly understood. We have taken a first step in this paper to explore the property 'free' and how it can lead to growth. As this is a multiple case study, larger studies would be needed to confirm and elaborate our findings. Furthermore, more in-depth case studies solely focusing on free users as a resource might be interesting to conduct.

For business model researchers it might be interesting to further explore the concept of the nascent business model which we present for the first time in this paper. In addition, like Demil and Lecocq (2010) we recognize that the freemium business model approach of various companies (in our case four case companies) differs, both in the value proposed to consumers and in how transactions are organized. At the individual level of analysis, each organization's own specific business model is linked to a more generic (i.e. a more conceptual) business model. In our case the freemium business model's archetype was linked to the multi-sided platform and long-tail business model archetype (for specification see Appendix 1). The question arises if certain combinations of business model archetypes yield superior performance? 


\section{Implications for practice}

Start-up and entrepreneurial firms' development has long been an important management research theme. The topic has significant appeal to entrepreneurs, management researchers, business consultants, investors and economic development agencies. Each of these stakeholders has an interest in understanding how and why growth occurs, as well as the entrepreneurial, organizational and strategic factors that influence an entrepreneurial venture's ability to achieve growth, and the paper suggests a growth model that differs in its logic and intermediary objectives and is suitable for the digital world.

Our research, thus, yields implications for managerial e-business practice. Free users appear to be of strategic interest for companies applying successfully freemium business models. This alters the companies' approach towards treating free users as a valuable resource and learning how to perform key activities by their means. Understanding free users in this light enables the company to build up a strong network, gain legitimacy and access to further resources. However, on the other side, free users are costly as any other valuable resource. A company needs to constantly innovate constantly for its free users and update their services. Here, entrepreneurs and managers need to consider a cost-benefit balance by reflecting on the market size, network externalities and number of paying customers.

Concluding, this study offers researchers and practicing e-business entrepreneurs a deeper appreciation of the challenges of growing an entrepreneurial venture online. Creative business ideas are valuable but present only an entry ticket to the game. In the e-business world, freemium can be used strategically to grow and become successful. Entrepreneurship and management scholars have hitherto neglected the value of freemium and its strategic importance. We show how freemium can be used strategically over the span of many years to grow an entrepreneurial venture. However, we need to state that this is a long process of experimentation and learning where the companies pay ongoing for the costs of their free users which need to be treated respectfully. In addition, we show the complexity that is associated with growing a freemium e-business venture successfully. No wonder that so few survive to bring about these fantastic online market offerings that we enjoy so much every day.

\section{References}

Achtenhagen, L., Naldi, L., \& Melin, L. (2010). "Business Growth"Do practitioners and scholars really talk about the same thing? Entrepreneurship Theory and Practice, 32(2), 289-316. 
Amit, R., \& Zott, C. (2001). Value creation in e-business. Strategic Management Journal, 22(6-7), 493-520.

Anderson, C. (2009). Free: The Future of a Radical Price: Random House.

Andries, P., Van Looy, B., Lecocq, C., \& Debackere, K. (2008, May). New ventures in emerging industries: Approaches to business model adaptation. Paper presented at the 16th HTSF High Technology Small Firms Conference, Twente, Netherlands.

Ardichvili, A., Cardozo, R., \& Ray, S. (2003). A theory of entrepreneurial opportunity identification and development. Journal of Business Venturing, 18(1), 105-123.

Baden-Fuller, C., \& Haefliger, S. (2013). Business models and technological innovation. Long Range Planning, 46(6), 419-426.

Baden-Fuller, C., \& Mangematin, V. (2013). Business models: A challenging agenda. Strategic Organization, 11(4), 418-427.

Baden-Fuller, C., \& Morgan, M. S. (2010). Business models as models. Long Range Planning, 43(2-3), 156-171.

Bamford, C. E., Dean, T. J., \& McDougall, P. P. (2000). An examination of the impact of initial founding conditions and decisions upon the performance of new bank start-ups. Journal of Business Venturing, 15(3), 253-277.

Baum, J. R., Locke, E. A., \& Smith, K. G. (2001). A multidimensional model of venture growth. Academy of Management Journal, 44(2), 292-303.

Bhide, A. (2000). The Origin and Evolution of New Businesses. New York, NY: Oxford University Press.

Birke, D., \& Swann, G. P. (2006). Network Effects and the Choice of Mobile Phone Operator. Journal of Evolutionary Economics, 16(1-2), 65-84.

Bosma, N., Jones, K., Autio, E., \& Levie, J. (2007). Executive Report Global Entrepreneurship Monitor: Babson College, Babson Park, MA, US, London Business School, London, UK.

Brokaw, L. (1993). The Truth About Start-Ups. Retrieved from http://www.inc. com/magazine/19930301/3440.html.

Casadesus-Masanell, R., \& Ricart, E. J. (2010). From strategy to business models and onto tactics. Long Range Planning, 43(2-3), 195-195.

Cavalcante, S. A., Kesting, P., \& Ulhøi, J. P. (2011). Business model dynamics and innovation: (Re)establishing the missing linkages. Management Decision, 49(8), 1327-1342.

Chesbrough, H., \& Rosenbloom, R. S. (2002). The role of the business model in capturing value from innovation: Evidence from Xerox Corporation's technology spin-off companies. Industrial and corporate change, 11(3), 529-555.

Clements, M. T. (2004). Direct and Indirect Network Effects: Are They Equivalent? International Journal of Industrial Organization, 22(5), 633645.

Conner, K. R. (1995). Obtaining Strategic Advantage from Being Imitated: When Can Encouraging "Clones" Pay? Management Science, 41(2), 209225. 
Daft, R. L., \& Lewin, A. Y. (1993). Where are the theories for the "new" organizational forms? An Editorial Essay. Organization Science, 4(4), i-vi.

Davidsson, P., Achtenhagen, L., \& Naldi, L. (2005). Research on small firm growth: A Review. Queensland University of Technology. Retrieved from http://eprints.qut.edu.au/2072/

de Reuver, M., Bouwman, H., \& Maclnnes, I. (2009). Business model dynamics: A case survey. Journal of Theoretical and Applied Electronic Commerce Research, 4(1).

Demil, B., \& Lecocq, X. (2010). Business model evolution: In search of dynamic consistency. Long Range Planning, 43(2-3), 227-246.

Dunbar, R. L. M., \& Starbuck, W. H. (2006). Learning to design organizations and learning from designing them. Organization Science, 17(2), 171-178.

Eisenhardt, K. M. (1989). Building theories from case study research. Academy of Management Review, 14(4), 532-550.

Eisenmann, T., Parker, G., \& Van Alstyne, M. (2011). Platform envelopment. Strategic Management Journal, 32(12): 1270-1285.

Froberg, P. (2015). What is freemium? Retrieved from www.freemium.org.

George, G., \& Bock, A. J. (2011). The business model in practice and its implications for entrepreneurship research. Entrepreneurship Theory and Practice, 35(1), 83-111.

Günzel, F., \& Holm, A. B. (2013). One size does not fit all - understanding the front-end and back-end of business model innovation. International Journal of Innovation Management, 17(1).

Gans, J. S., \& Stern, S. (2003). The product market and the market for "ideas": commercialization strategies for technology entrepreneurs. Research Policy, 32(2), 333-350.

Google Inc. (2013). Financial tables. Retrieved from http://investor.google. com/financial/2013/tables.html

Hancock, D. R., \& Algozzine, B. (2006). Doing case study research: A practical guide for beginning researchers. New York: Teachers College Press.

Holm, A. B., Günzel, F., \& Ulhøi, J. P. (2013). Openness in innovation and business models: Lessons from the newspaper industry. International Journal of Technology Management, 61(3/4), 324-348.

Johnson, M. W., Christensen, C. M., \& Kagermann, H. (2008). Reinventing your business model. Harvard Business Review, 86(12), 50-59.

Kazanjian, R. K., \& Drazin, R. (1990). A stage-contingent model of design and growth for technology based new ventures. Journal of Business Venturing, 5(3), 137-150.

Kesting, P., \& Günzel-Jensen, F. (2015). SMEs and new ventures need business model sophistication. Business Horizon, 58(3): 285-293.

Leitch, C., Hill, F., \& Neergaard, H. (2010). Entrepreneurial and Business Growth and the Quest for a "Comprehensive Theory": Tilting at Windmills? Entrepreneurship Theory and Practice, 34(2), 249-260.

Levinthal, D. A., \& March, J. G. (1993). The Mytopia of Learning. Strategic Management Journal, 14(S2), 95-112. 
Lincoln, Y. S., \& Guba, E. G. (1990). Judging the quality of case study reports. International Journal of Qualitative Studies in Education, 3(1), 53-59.

Low, M. B., \& MacMillan, I. C. (1988). Entrepreneurship: Past research and future challenges. Journal of Management, 14(2), 139-161.

Martins, L. L., Rindova, V. P., \& Greenbaum, B. E. (2015). Unlocking the hidden value of concepts: a cognitive approach to business model innovation. Strategic Entrepreneurship Joural, 9(1), 99-117.

Massa, L., \& Tucci, C. L. (2013). Business model innovation. In M. Dodgson, D. M. Gann \& N. Phillips (Eds.), The Oxford Handbook of Innovation Management (420-441), Oxford University Press.

McGrath, R. G. (2010). Business models: A discovery driven approach. Long Range Planning, 43(2-3), 243-261.

McKelvie, A., \& Wiklund, J. (2010). Advancing firm growth research: A focus on growth mode instead of growth rate. Entrepreneurship Theory and Practice, 34(2), 261-288.

Mendelson, H. (2000). Organizational architecture and success in the information technology industry. Management Science, 46(4), 513-529.

Miles, M. B., Huberman, M. A., \& Saldana, J. (2014). Qualitative Data Analysis (3rd ed.). Thousands Oaks, CA: SAGE.

Osterwalder, A., \& Pigneur, Y. (2010). Business Model Generation. Hoboken, NJ: John Wiley \& Sons, Inc.

Piskorski, M. J. (2007). LinkedIn (A). Cambridge, MA: Harvard Business School. Pujol, N. (2010). Freemium: attributes of an emerging business model. Retrieved from http://ssrn.com/abstract=1718663.

Reynolds, P., \& Miller, B. (1992). New firm gestation: Conception, birth, and implications for research. Journal of Business Venturing, 7(5), 405-417.

Ridder, H.-G., Hoon, C., \& McCandless, A. (2009). The theoretical contribution of case study research to the field of strategy and management. Research Methodology in Strategy and Management, 5, 137-175.

Salganik, M. J., Dodds, P. S., \& Watts, D. J. (2006). Experimental Study of Inequality and Unpredictability in an Artificial Cultural Market. Science, 311(5762), 854-856.

Sosna, M., Trevinyo-Rodriguez, R. N., \& Velamuri, S. R. (2010). Business Model Innovation through Trial-and-Error Learning: The Naturehouse Case. Long Range Planning, 43(2-3), 383-407.

Strahilevitz, L. J. (2003). Charismatic Code, Social Norms, and the Emergence of Cooperation on the File-Swapping Networks. Virginia Law Review, 89(3), 505-595.

Sylvester, J., \& Rand, W. (2014, February) Keeping Up with the (Pre-Teen) Joneses: The Effect of Friendship on Freemium Conversion. Paper presented at the Winter Conference on Business Intelligence, Snowbird, Utah.

Teece, D. J. (2007). Explicating dynamic capabilities: the nature and microfoundations of (sustainable) enterprise performance. Strategic Management Journal, 28(13), 1319-1350. 
Teece, D. J. (2010). Business models, business strategy and innovation. Long Range Planning, 43(2-3), 172-194.

Vaccaro, V. L., \& Cohn, D. Y. (2004). The Evolution of Business Models and Marketing Strategies in the Music Industry. International Journal on Media Management, 6(1-2), 46-58.

Voelpel, S. C., Leibold, M., \& Tekie, E. B. (2004). The wheel of business model reinvention: how to reshape your business model to leapfrog competitors. Journal of Change Management, 4(3), 259-276.

Wang, C. C., Hsu, Y., \& Fang, W. 2004. Acceptance of Technology with Network Externalities: An Empirical Study of Internet Instant Messaging Services. Journal of Information Technology Theory and Application, 6(4),15-28.

Yin, R. K. (2003). Case study research: Design and methods. Thousand Oaks, London, New Delhi: Sage.

Zott, C., \& Amit, R. (2007). Business model design and the performance of entrepreneurial firms. Organization Science, 18(2), 181-199.

Zott, C., Amit, R., \& Massa, L. (2011). The business model: Recent developments and future research. Journal of Management, 37(4), 1019-1042.

\begin{abstract}
Abstrakt (in Polish)
W e-biznesie modele biznesowe Freemium staty się legalne. Jednak obecne badania dostarczaja znikomej wiedzy na temat sposobu w jaki oferta free i premium powinna być użyta, by w dłuższej perspektywie doprowadziła do wzrostu i sukcesu firmy. Prezentowane badanie ma na celu wypełnienie tej luki poprzez zbadanie, w jaki sposób cecha "free" została zastosowana w modelach biznesowych młodej przedsiębiorczości w poczqtkowej fazie etapów cyklu życia - rozpoznaniu możliwości, wejścia na rynek, i eksploatacji rynku. Uważamy, że różne formy modeli biznesowych Freemium sq stosowane w poczqtkowych etapach cyklu życia nowego przedsięwzięcia z powodu prób i błędów, uczenia się, poszukiwania, legitymizacji i pozyskiwania zasobów. Model biznesowy Freemium może również służyć jako powstajqcy model biznesowy, choć bez trwałego komponentu monetyzacji, może być wykorzystany w celu znalezienia trwałego modelu biznesowego poprzez serię dynamicznych zmian. Nasze ustalenia to wkład w literaturę dotyczqca modelu biznesowego na trzy sposoby: po pierwsze, nasze badania empiryczne pokazujq wielowymiarowość komponentu "free" w modelach biznesowych Freemium. Darmowi użytkownicy majq znaczenie dla budowania sieci, poszukiwania i eksploatacji oraz rozwoju z upływem czasu. Ponadto, tacy użytkownicy umożliwiajq, bezpośrednio i pośrednio, dalsze pozyskiwanie zasobów. Po drugie, podczas gdy dotychczasowa literatura prezentowała perspektywę statycznq, nasz wkład ilustruje dynamiczny proces projektu strategicznego modelu biznesowego na rzecz jego wzrostu. Wreszcie, wprowadzamy pojęcie powstajqcego modelu biznesowego, który jest nowy w literaturze.
\end{abstract}

Słowa kluczowe: model biznesowy, studium przypadku, przedsięwzięcie przedsiębiorcze, Freemium, wzrost, IT, powstajqcy model biznesowy. 


\section{Biographical notes}

Franziska Günzel-Jensen is Assistant Professor at the Department of Business Administration, Aarhus University, Denmark. She holds a PhD (2011) in Entrepreneurship from the Otto von Guericke University, Germany. Her research focuses on entrepreneurial decision-making, nascent entrepreneurship, business model development and design, and qualitative research methods. Franziska has advised start-ups with very diverse backgrounds from 2004 to today.

Anna B. Holm is Associate Professor at the Department of Business Administration, Business and Social Sciences, Aarhus University, Denmark. She has a PhD (2010) in organization and management theory from Aarhus University, and an MBA (1995) from the Bradford University School of Management, UK. Dr. Holm's research area includes business model design and strategic management. Prior to her academic career, Dr. Holm worked for over a decade as a business development consultant and in various managerial positions in industry. 


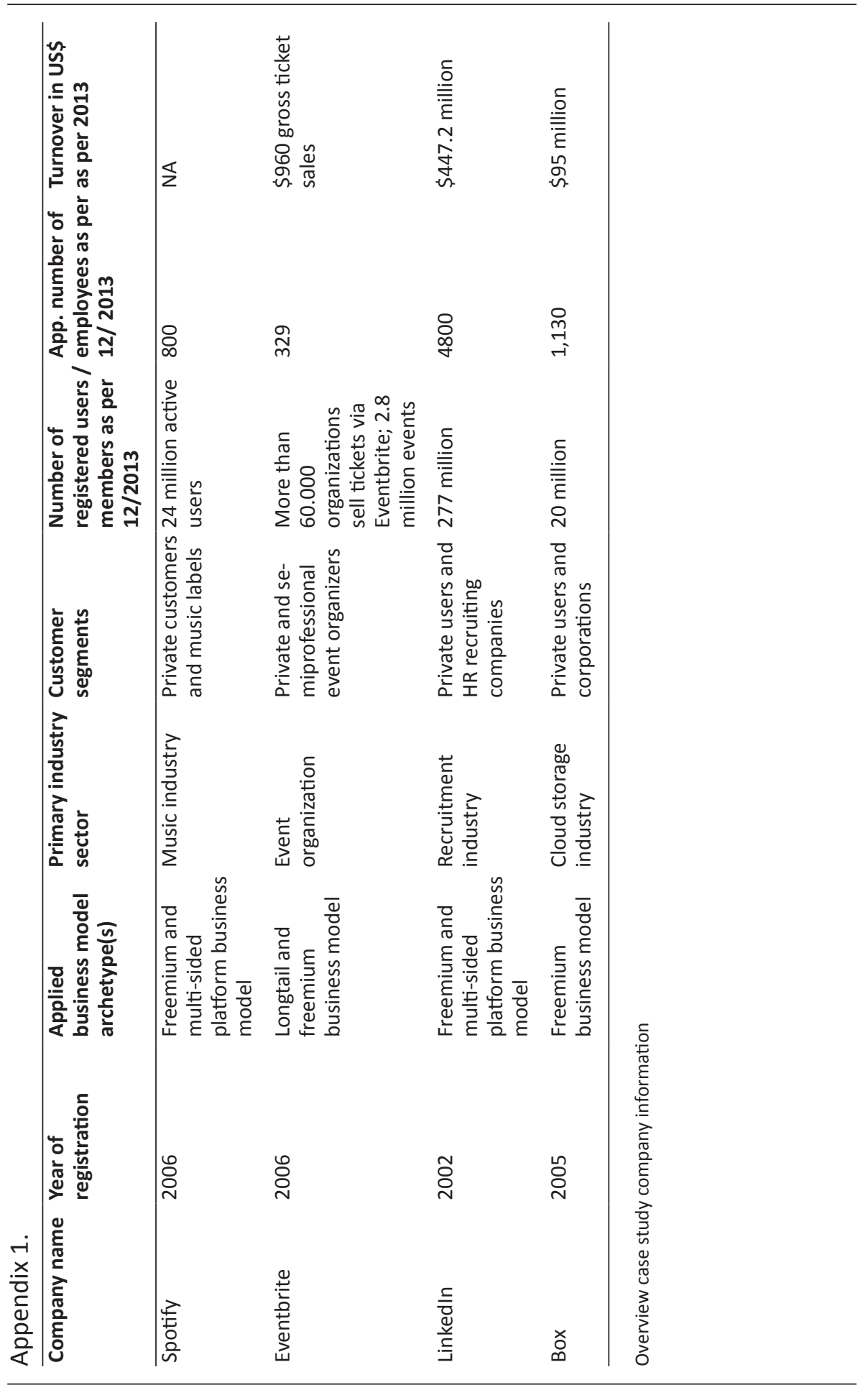





\title{
Developing Innovative Business Models in Social Ventures
}

\author{
Päivi Jokela', Maria Elo²
}

\begin{abstract}
Social ventures represent a new type of organization that aim to create sustainable social value, such as promoting the well-being of communities and their existence is based on developing solutions to tackle complex social problems. Developing a suitable business model for a social venture is crucial because the right model with a sustainable value offering in its core can support the venture and direct it toward self-sustainability and competitiveness. Research on social venture business models has been so far limited and particularly innovation in business models needs more inquiry. Through an in-depth case study, we aim to extend the understanding how business models of social ventures can meet these goals and how the business model elements interact with each other. The study findings indicate that opportunity recognition which is followed by innovative resource mobilization and integration can turn into a well-functioning business-model that serves the desired ends, creating social value and help to achieve self-sustainability. Furthermore, establishing the right interconnections between the business model elements was found to support the development of an efficient social venture business model.

Keywords: social entrepreneurship, social ventures, business models, social value creation.
\end{abstract}

\section{INTRODUCTION}

The growing interest in working for the common good is manifested not only in corporate social responsibility initiatives, but also in the emergence of new organizations, social ventures specializing in running projects among less privileged groups of people and thus responding to social problems and injustices (Haynes, 2012; Felicio et al, 2013; Sud et al, 2009). Social entrepreneurship is thus driven by the need for social change, and social entrepreneurs act as change agents in adopting a mission to create and

\footnotetext{
1 Päivi Jokela, Postdoctoral researcher Dr, Turku School of Economics at the University of Turku, Department of Marketing, Fl-20014 Turun yliopisto, Finland, tel.: +358 2333 51, email: paivi.jokela@utu.fi.

2 Dr. Maria Elo, Turku School of Economics, University of Turku, Rehtorinpellonkatu 3, 20500 Turku, Finland, tel. +358 2 33351, e-mail: maria.elo@utu.fi.
} 
sustain social value instead of value measured in economic terms only (Choi \& Majumdar, 2013; Dees, 1998).

This evolving phenomenon has been acknowledged as a new type of entrepreneurship, drawing scholars to find a position for it in the entrepreneurship literature, which has traditionally focused on the wealth creating aspects of entrepreneurial activity (Haynes, 2012). The elevation of the social dimension has even been interpreted as a paradigm change and there is a growing body of literature that is focused on defining the phenomenon (Choi, 2013; Haynes, 2012; Short et al, 2009). The various definitions provide a multi-faceted description of what social entrepreneurship is, and how it has been approached. According to Oncer et al. (2010), social entrepreneurship is distinguished by the motivation and the purpose of the activity (Thake \& Zadek, 1997), with innovation in its core (Dees, 1998) together with accumulation of benefits and social value for various segments of the society (Austin et al, 2006; Zahra et al, 2009; Mair \& Marti, 2009). Particularly creation of social value has been a central point of interest in research on social entrepreneurship and it has been defined as both a preconditional purpose and an outcome of it (Mort et al. 2003; Thomson \& Doherty, 2006).

In spite of value creation's close connection to the development of efficient and competitive business models that are needed in order to achieve the desired ends (Alter, 2006) we still are lacking a systematic inquiry on how these models are developed and how they can best serve the mission of social ventures. While the abundancy of studies on business models of commercial ventures (see e.g. Chesbrough, 2007; Morris et al, 2005, Osterwalder, 2004) can contribute to understanding the models in social ventures to a certain extent, the special characteristics of the ventures require a more focused approach. Particularly the aspects of self-sustainability, competitiveness and innovation as part of the social venture goals set certain requirements and have to be considered in the development of business model for social ventures (Grassl, 2010). In these ventures business models can help to map the functions that are needed to maintain the activities. An important part of this process is to identify the funding stream and define how the income opportunities are created since in the new ventures the traditional donationbased strategies are often replaced with the income generating commercial projects. Business models can thus also help to outline the relationship between the business activities and social programmes and illustrate how social value and economic value are created (Alter, 2006).

Aimed at increasing the theoretical and practical knowledge of social ventures, this study explores and analyses a business model of a social venture that holds a portfolio of multiple social projects. The study addresses the key questions how the model is constructed in order to achieve self-sustainability 
by using innovation and how the model elements interact in the process supporting the model development. The methodology is qualitative and the inquiry was conducted by using case study strategy.

The paper is structured in a following manner: the second section introduces the concept of social venture and the elements of business model, presenting the theoretical framework for the study. The third section discusses the study methodology introducing briefly the case and the fourth section describes the case and the findings on its business model. The fifth section includes conclusions and discussion.

\section{THEORETICAL FRAMEWORK}

\section{Social ventures}

Social ventures can take many forms and there are numerous options how their activities are financed, what they offer and to whom. Social organizations can be run by volunteer resources or they can be funded by governments and private donations representing the traditional approach of non-profit organizations. They can include also for-profit firms with social offering ventures that focus on social outcomes as the main source of their profit, (e.g. health care services for the elderly replacing the public system) or any hybrid forms of these organizations (Felicio et al, 2013;) and as where the point of interest of this study is, organizations that look for innovative ways to finance their activities (Alter, 2006; Grassl, 2010). Social venturing can also be part of large corporations' social responsibility activities, with an appointed person or group taking the role of social entrepreneur within the organization.

While the pure commercial business ventures operating in the social space address markets that are often divided to certain customer segments, the concept of "markets" in social ventures is wider. It includes both the populations that participate in the social programmes offered by the venture, often with no cost, or the ventures can have a clientele base that pay for the social services or other services (Alter, 2006; Grassl, 2010). We discuss this further in the next section and propose that this division of markets impacts how the business model should be outlined.

Despite similarities between social and commercial ventures, it has been proposed that the key differentiating factor is the motivation of the key decision makers who get involved in the social activities, and the mission of the organization (Haynes, 2012). The distinction can be drawn between organisations where the purpose of the venture is to create social value, as opposed to private wealth (Austin et al., 2006). Social ventures can also be 
profit-oriented with the distinction that the wealth accumulated is injected back to the venture to provide means for the future projects (Grassl, 2010). It is also suggested that the focus may shift over time. In spite of an initial emphasis on the social ends, with increasing recognition or legitimacy, or both, the entrepreneurs may need to scale up their efforts and leverage their resources by adopting a more commercial approach (Austin et al., 2006).

In this study we use the narrow definition of social entrepreneurship, focusing on ventures that are founded to fulfil a social mission, based on an observed opportunity and innovation, with the aim of creating sustainable social value for the target audiences.

\section{Business models in social ventures}

The interest in business models has been growing as firms have realized that mapping their activities and understanding the relationships between the different business models elements. In the extant literature they commonly include value proposition or the offering, which can be a product or service or their combination, target markets, channels and networks that serve as an intermediate in the value offering delivery process, key resources that are needed internally and the financial element that explains the firm's revenue logic and cost structure (Osterwalder, 2004).

According to Grassl (2010) the business models of social ventures should fulfil the following conditions: to 1 ) be driven by a social mission and therefore the focus is not on distributing profit to shareholders 2) have a positive impact on society 3 ) recognize the centrality of the entrepreneurial function; and 4) support achieving competitiveness on markets through effective planning and management.

These conditions are further elaborated below from the perspective of developing a viable business model for social ventures.

Social ventures by definition should be attentive to the socially desired distribution of results and tie making profits to the social mission to support the cause of the venture (Grassl, 2010). Income earned and financial leveraging through business-oriented resource management enables practitioners to make new social project-related investments (Alter, 2006). Alter (2006) proposes further that this may be achieved the social projects and commercial activities can be integrated by commercializing social services to new fee-paying markets or by providing new services to existing clients. This is characterized as "integrated" social ventures, the target groups benefiting from investments made in social programmes through the earned income, irrespective to their involvement in the venture's operations (Alter, 2006). For this reason also the business model elements can firstly be studied at target 
population level, identifying the beneficiaries, their needs and the means of the venture to meet those needs. Secondly, social ventures can develop models for the customers that by accepting the value offering participate as value co-creators in the venture activities.

Social value creation forms the primary objective and precondition for social venture establishment (Choi \& Majumdar, 2013; Mair \& Martí, 2006) and it refers to the production of such offerings and their outcomes that advance justice, fairness and welfare in a given human community (Austin et al., 2006; Peredo, 2006). The value created can take tangible or intangible forms, expressed often in terms of social inclusion of less privileged groups through the following concepts: well-being, social responsibility, social recognition, proximity, human development, involvement and engagement (Felício et al., 2013; Omidvar \& Richmond, 2003). According to Omidvar and Richmond (2003) the overall aim of social inclusion is to close the physical, social and economic distances separating people, rather than only to remove the barriers existing between different groups.

Ventures thus often aim to achieve a wider society-related impact, which can be mediated by the target group, or, depending on the focus of the venture, the primary target group can be the society as a whole, for example, software that is developed by volunteers to benefit citizens by providing information concerning society-related decisions (http://www.hasadna.org. il/en/our-projects/open-knesset/). Although measuring social impact and value is challenging, and only in certain cases the results can be measured, for example, in the development of skills, reduced use of energy, etc., this is not the even the primary objective in all social ventures (Austin et al., 2006).

Key processes in the social ventures like in any enterprise are the opportunity recognition and assembly of resources: people, relationships and skills in a novel way. According to Felício et al. (2013), the entrepreneurial orientation of the venture managers has a positive effect on the creation of social value. Social innovations imply creating novel approaches for tackling social issues, and they form an essential element in social entrepreneurship (Choi \& Majumdar, 2013). Organizations with higher initiative and more innovation contribute to the achievement of greater value (Felício et al., (2013). 


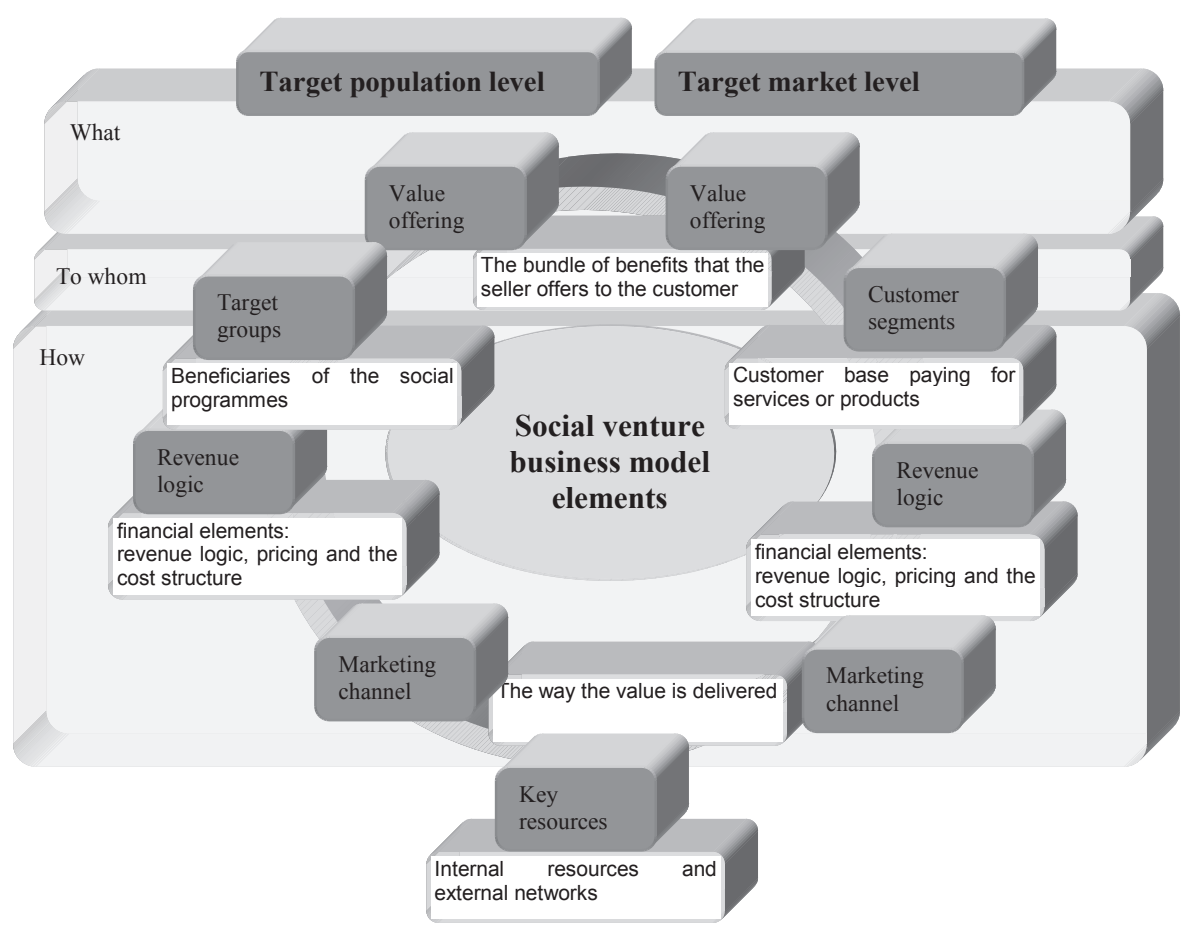

Figure 1 Zeze business model elements

Source: The authors, modified based on Osterwalder (2004).

Also other business model elements that are presented in Figure 1 can be examined separately following the proposed division. Depending on the nature of the social venture some of the elements may not have significance (e.g. revenue model at the target population level as the beneficiaries may not pay for the services they receive and could be replaced with "value creation logic") or their contents can be different than in commercial organizations. This concerns especially the key resources. While corporations running social programs benefit from the specialized skills and capabilities that they have in their business management (Hess et al., 2002), social ventures can rarely claim the same. Although social ventures could have much flexibility in terms of planning and testing models with novel elements, it does not change the fact that there has to be a match between the purpose of the venture and its resources. Configuration of these two can be continuously evolving because the economic, sociocultural and political context, and also the available resources can be expected to change, requiring realignment and the awareness of the entrepreneur (Austin et al., 2006). The result should be 
a competitive and sustainable model that supports the venture activities and continuous venture development.

\section{Methodology}

This qualitative study, constructed as a case study (Yin, 1984), follows an explorative and descriptive strategy, attempting to widen understanding of the complex, real-life concept of social entrepreneurship. Both primary and secondary data were collected from multiple sources (Alasuutari, 1995) and these were analysed and compared to provide an in-depth picture of business models in the context of social entrepreneurship (Helkama, Myllyniemi \& Liebkind, 2010; Stake, 2005). The focal case study was purposefully selected to match the criteria describing social venture including the idea of striving for competitiveness and fostering innovation in their activities which also was reflected in its business model (Choi \& Majumdar, 2013; Grassl, 2010). The Tel Aviv-based social venture Zeze was established in 2010 as a continuation of activities of two brothers who recognized a need for providing interesting activities for the elderly. Zeze is dedicated to carrying out social projects with the aim of making a sustainable social impact. The venture is based on a platform that provides a basis for different types of social projects, run mainly by young volunteers. It looks for projects with creative elements, and thus offers an innovative way of getting young people involved. In Zeze, the management of the projects takes place through different layers. The core team consists of the founders and the CEO of the venture, and beyond that there are 40 more permanent volunteers and other volunteers, with the number involved in their projects already up to one thousand.

The primary data was collected in Israel in 2011-2014 by interviewing the key informants the social entrepreneurs in three different occasions. Short follow-up questions and verifications were asked also of the family members of the entrepreneurs, because of their role in supporting the venture development with their business experience and thus contributing to the formation of the venture. The secondary data includes video clips about the activities of the venture, interviews with the founders and key managers, newspaper articles and materials published by the company on their website. A longitudinal approach was adopted in data collection, as the social venture and its development were followed for three years. The case analysis was guided by the concepts of the theoretical framework, the business model elements and the criteria proposed for the models. Aligned with the tradition of interpretative sense-making, the findings indicate implications that are idiographic and seek to understand the particular rather than to generate law-like explanations (Welch et al., 2011). On the other hand, considering 
the contextual factors, the results can to a certain extent be transferable. The value of the case study lies in the rich description and the possibility to contribute to understanding better the logic of the social ventures, the innovation in the development of their business model and achieving selfsustainability.

\section{CASE DESCRIPTION OF - ZEZE SOCIAL PROJECTS BUSINESS MODEL}

\section{Background}

When a young Israeli man, on completing his national service in an elderly day-care centre, shared with his friend Daniel his concern that there was a lack of interesting activities for the elderly, or the funding required for them, they felt that they could do something about it. However, they also decided that the conventional approach of asking for donations would be very boring, and they would try to think of funding the activities in some other way. They came up with an idea of organizing parties for young people that would create the needed revenue for the day-care centre activities. The founders also reasoned that for the young volunteers that they intended to recruit the typical NGO's with their hierarchical structures, bureaucracy, and the traditional ways of helping people would not necessarily be appealing. Their expectation was that this alternative would make a difference as the participation in the activities should be fun, and that the volunteers should be able to use their talents. This was indeed the case as a great number of young volunteers offered their skills and time to promote the events and take care of the arrangements for the parties, which turned out to be successful.

The income from the parties was used to maintain and develop various new projects with an aim of creating social value in its different forms for the target groups. The participation of the volunteers and the value creation for them was emphasized as well. The idea of Zeze was crystallized by one of the founders in the following way: "These are the criteria for how we do projects: the projects have to be creative and they have to have a social aim of course. They also have to empower both sides, both the volunteer and also the social target."

Besides the creating activities for the elderly, there was a project called Zotzot that helped former female prisoners by teaching them graphical design skills, with the purpose of preparing items for sale, and ultimately assisting women in rehabilitation to find their way back into normal life. Another successful project took place by setting up a special orchestra, the Streets Philharmonics. This project targeted immigrants who are talented musicians, mainly from the former USSR, and who found it difficult to penetrate Israel's 
small music industry. The Zeze founders approached these musicians on the streets where they were playing, and proposed that they could join the orchestra. The performances were a huge success, with audiences of up to a thousand at a concert, and firms and government institutions commissioned the orchestra to play at their events. The musicians were paid from the concert revenues according to the standards of the music industry. In the past, Zeze also managed a project that organized summer camps for children from lower socio-economic neighbourhoods in Tel Aviv. For this project, Zeze provided opportunities for older school kids to participate as counsellors, to receive experience and a proper salary. These counsellors represented minorities from rough neighbourhoods: Arabs, African refugees and Ethiopians.

In addition to the volunteers and few staff with salary, there have been students who got involved through collaboration between Zeze and Tel Aviv University, and the Shenkar College of Engineering and Design. Through these academic organisations scholarships were made available for participants. One of the founders described the method in the following statement: "The project's participants receive mentoring, funds and the connections needed from the community, in order to bring unique social projects to life."

\section{THE BUSINESS MODEL OF ZEZE SOCIAL VENTURE - FINDINGS}

\section{The social venture model criteria at Zeze}

Zeze's business model fit to the criteria set for social venture model by Grassl (2010), including the focus on and drive by social mission, creation positive spillovers impacting the society, recognizing the centrality of the entrepreneurs and entrepreneurial process; and achieving competitiveness on markets through effective planning and management.

It was obvious that Zeze was to a great extent focused on their social mission. It succeeded in combining social ends with revenue generation while benefitting the customers, volunteers and other stakeholders, thereby providing intelligently planned means to maintain their social activities. The social impact achieved by the venture was multifaceted. The venture fulfilled the original purpose of creating sustainable social impact in the target audience by creating feelings of integration, support as a result of group activity, and satisfaction from the participation, but in addition, there were other, unplanned positive impacts that occurred: the volunteers benefited from involvement as their skills and experience accumulated in the areas of their expertise. One example was a young man who developed the promos for the events and was subsequently able to use the works as references when opening his own business. Also a junior graphic designer was given the 
opportunity to design a one-page advertisement for a prominent newspaper. Building such a wide portfolio and winning a place in a country-wide newspaper would have hardly been possible for these young professionals without their involvement with Zeze.

Value created in the form of inclusion, or by providing benefits for less privileged groups, such as school children, the elderly or immigrants, was the main focus of Zeze. For the musicians their inclusion provided an employment opportunity, an income and a stage to use their talents on a more appreciated platform and as a part of an orchestra rather than just playing alone on the street, although Zeze does also recognise street music as a significant form of the arts. However, from the musicians' point of view, the importance of receiving a salary was sometimes of lesser importance than their increased confidence derived from playing on the stage for a large audience. Importantly, commercial firms formed a significant customer base for the Streets Philharmonics. The various backgrounds of the musicians added value to the orchestra, as reference to the world music they represented was used in marketing the concerts. Teaching graphic design to former prisoners contributed to their inclusion, as the project encouraged them both through learning new skills and through the results of their work. In the school children project, according to the founder, it was empowering for the counsellors to see that they could be a "part of the solution for others" and not only to be considered as those whose problems needed to be solved.

The entrepreneurs and the opportunity recognition process were central for developing the venture and their motivation was to make a change. This also applied to the managers who were hired for the projects when the activities matured and there was a need for a more professional management. The salaries offered were lower than in the business sector implying that the key people had to be motivated by the cause of the project. However, according to the founders, this should not necessarily be the case. They believe that a social venture should find a model that is fully self-sustainable and comparable to commercial ventures, at least in terms of hiring key managers.

The competitiveness criterion was already met to great extent with the current model of Zeze. Creating revenue from certain social projects and investing the income in other projects turned out to be a successful way of financing the activities. The skills and knowledge base of the volunteers formed the basis for carrying out the projects and it was assessed the young people were doing a very good job. 


\section{Zeze's business model}

The Zeze's business model was in accordance with the two-level model of social ventures introduced in the section 2.2. Firstly, there were various target populations who participated in the projects, from the musicians to children in need. Secondly, there were different customer segments that participated in value creation by generating revenues for the projects, including young people who came to the parties and various concert audiences. An important group within the latter were companies that could, in this way, demonstrate social responsibility to their own stakeholders. When events were offered to the wider public, the venture itself benefited from this, because awareness often turned into people's willingness to get involved. The value offering for the target population included various activities aiming at their inclusion, but for the customer segments the venture developed different marketable products, e.g. the parties, the plates designed by the women, or the concerts.

The channel element as focused on marketing and it was largely based on the use of Internet and word of mouth on both target market levels. The use of social media in marketing Zeze activities and locating suitable volunteers was essential, but the events spread the word about these activities, providing thereby not only a marketing channel for new customers, but also for new volunteers.

Besides the volunteers, the people that targeted with the projected formed also a key resource for the same projects in the case of concerts and children camps. The revenue logic was that the ticket sales invested back to support the activities and for the target populations' participation in projects was of no cost but on the contrary, in some cases it also created income for them. Figure 2 above illustrates the Zeze business model and it has been modified to correspond to the social venture model.

\section{DISCUSSION AND CONCLUSIONS}

The study enriches the extant theoretical views on social ventures and social entrepreneurship by contributing to the understanding of social venture business models and the linkages between the model elements. The case study on Zeze projects reveals how innovation in the business model elements and in their interrelations can impact the venture self-sustainability and help locating the required resources for maintaining the venture activities and achieving the desired social ends. Our findings show that underprivileged groups including immigrants, children from low-socio-economic backgrounds, the elderly and former prisoners, still are the main target audience benefitting from social inclusion in its various forms (Austin et al., 2006; Sud et al., 2009). The tangible and intangible elements of social inclusion, material well- 
being, recognition and involvement were ways of value creation (Omidvar \& Richmond, 2003). However, the value was observed to flow in the venture bidirectionally: toward the pre-defined target audiences but also toward the other participating groups, including business organizations that were active parties in roles other than that of a donor.

Based on the analysis of the results, the earlier definitions of social ventures and the criteria set for their business models that emphasized the role of the social entrepreneur as a driving force, the overall social impact through value creation, innovativeness in the venture activities and competitiveness (Austin et al., 2006; Choi \& Majumdar, 2013; Felicio et al., 2013; Grassl, 2010; Mair \& Martí, 2006) were clearly manifested in the Zeze projects. This opens new avenues for understanding the venture models via the studied case.

The model elements from the two different levels, target population and target market level, were interrelated in several ways. The earlier suggestion of Alter (2006), according to which it is difficult to employ the target groups in projects or that the employment may not contribute to the venture's competitiveness in a desired manner was contradicted in this study. Several different target groups were involved in the venture projects served as key resources either provided their time in the voluntary projects to help for others or brought their skills to bring finances for the other projects in the portfolio, like the musicians did. In the case of Zeze, the innovativeness lies in the processes of resource integration and mobilization, and in the venture model itself, more than in its outcomes. A key to the competitiveness and sustainability was thus on the one hand in the innovative nature of fundraising and locating the right volunteers to serve as resources for it as well as in the diversification of the projects that supported one another. In other words the model was designed in such a way that it supported the construction of a network of people, its key resource and an essential element in maintaining the activities. In the model development the entrepreneurs emphasized innovation and using great creativity in their planning the model. An important driving force here was their own social setting and demographical factors: From this perspective the young entrepreneurs recognized the opportunities and acted upon seizing them accordingly.

Creating marketable products and services for an expanding customer base placed Zeze into the category of hybrid ventures that combining social activities with commercial ends (Grassl, 2012). The marketable idea that was turned into a successful value offering was a key to revenues which were invested back into the venture allowing development of existing projects and the launching of new ones from the same platform. This is contrary to the traditional approach to social organizations that highlights donations or 
governmental support (Felicio et al., 2013). The commercial aspect assures independence for the venture and allows greater flexibility in relation to the contents of the projects and their target audiences. For the customers, including the corporate or other institutional actors who buy concerts and concert tickets, involvement in the venture reflects their socially responsible activities and manifests through an enhanced corporate reputation as perceived by their stakeholders. Through the creativity exercised in planning the activities, the venture has been able to reach out to a great number of young people and lead them to get engaged by allowing them to follow their passion in doing things that they would be doing otherwise anyway. For the volunteers, the development of skills was significant within the framework of the venture when they participated in creating the value offerings.

The limitations of the study relate to the size of the studied population. The future aim is to include more and varying yet comparable cases to assess the aspects of this study in different settings. This would enrich the learning from models of different organizations and their way of handling innovation and self-sustainability related issues that form the imminent challenge for social ventures.

\section{References}

Alasuutari, P. (1993). Laadullinen tutkimus, Vastapaino: Tampere.

Alter, S. (2006). Social enterprise models, their mission and money relationships. In: A. Nicholls, (Ed.) Social entrepreneurship: new models of sustainable social change, 205-232, University Press: New York.

Austin, J., Stevenson, H. and Wei-Skillern, J. (2006). Social and Commercial Entrepreneurship: Same, Different, or Both? Entrepreneurship Theory and Practice, 30(1), 1-22.

Chesbrough, H. (2007). Business Model Innovation: It's Not Just About Technology Anymore. Strategy \& Leadership, 35(6), 12-17.

Choi, N. and Majumdar, S. (2014). Social Entrepreneurship as an Essentially Contested Concept: Opening New Avenue for Systematic Future Research, Journal of Business Venturing, 29(3), 363-376.

Dees, G. (1998). The meaning of "social entrepreneurship. Draft Report for the Kauffman Center for Entrepreneurial Leadership: Stanford University.

Felício, J., Gonçalves H. M. and Gonçalves, V. da C. (2013). Social Value and Organizational Performance in Non-profit Social Organizations: Social Entrepreneurship, Leadership, and Socioeconomic Context Effects. Journal of Business Research, 66(10), 2139-2146.

Grassl, W. (2012). Business Models of Social Enterprise: A Design Approach to Hybridity, ACRN Journal of Social Entrepreneurship Perspectives, 1(1), 37-60. 
Haynes, P. (2012). The Social of Social Entrepreneurship: Building a New Field Using a New Paradigm, American Journal of Entrepreneurship, 5(1), 5769.

Hess, D., Rogovsky, N. and Dunfee, T. W. (2002). The Next Wave of Corporate Community Involvement: Corporate Social Initiatives. California Management Review, 44(2), 110-125.

Mair, J. and Marti. I. (2006). Social Entrepreneurship Research: A Source of Explanation, Prediction, and Delight. Journal of World Business, 41(1), 36-44.

Morris, M., Schindehutte, M. and Allen, J. (2005). The Entrepreneur's Business Model: Toward a Unified Perspective. Journal of Business Research, 58(6), 726-735.

Mort, G.S., Weerawardena, J. and Carnegie, K. (2003) . Social Entrepreneurship: Towards Conceptualisation, International Journal of Nonprofit and Voluntary Sector Marketing, 8(1), 76-88.

Omidvar, R. \& Richmond, T. (2003). Immigrant Settlement and Social Inclusion in Canada. (Working Paper Series Perspectives on Social Inclusion: Laidlaw Foundation). Retrieved from http://library.bsl.org.au/jspui/ bitstream/1/626/1/Immigrant_Settlement_and_Social_Inclusion_in_ Canada.pdf.

Oncer, A. Z. and Yildiz, M. L. (2010). Creating Sustainable Value for Society: Social Entrepreneurship. The Business Review, Cambridge, 14(2), 222 228.

Open Knesset-project. Retrieved from http://www.hasadna.org.il/en/ourprojects/open-knesset/.

Osterwalder, A. (2004). The Business ModelOntology-AProposition In a Design Science Approach, (PhD dissertation, University of Lausanne). Retrieved from http://www.hec.unil.ch/aosterwa/PhD/Osterwalder_PhD_ BM_Ontology.pdf.

Peredo, A. and McLean, M. (2006). Social Entrepreneurship: A Critical Review of the Concept. Journal of World Business. 41(1), 56-65.

Short, J.C., Moss, T.W. and Lumpkin, G.T. (2009). Research in Social Entrepreneurship: Past Contributions and Future Opportunities. Strategic Entrepreneurship Journal, 3(2), 161-194.

Sud, M., VanSandt, C.V., Baugous, A. M. (2009). Social Entrepreneurship: The Role of Institutions. Journal of Business Ethics, 85(1), 201-216.

Thake, S. and Zadek, S. (1997). Practical People, Noble Causes: How to Support Community Based Social Entrepreneurs, New Economic Foundation.

Zahra, S. A., Gedajlovic, E., Neubaum, D. O. and Shulman, J. M. (2009). A Typology of Social Entrepreneurs: Motives, Search Processes and Ethical Challenges. Journal of Business Venturing, 24(5), 519-532.

Welch, C., Piekkari, R., Plakoyiannaki, E. and Paavilainen-Mäntymäki, E. (2011). Theorising from Case Studies: Towards a Pluralist Future for International Business Research, Journal of International Business Studies. 42(5), 740-762. 
Yin, R. (1989). Case study research: design and method. Sage Publications: New York.

\begin{abstract}
Abstrakt (in Polish)
Przedsięwzięcia społeczne reprezentujq nowy typ organizacji, których celem jest stworzenie trwałej wartości społecznej, takiej jak promowanie dobrobytu społeczności, a ich istnienie opiera się na tworzeniu rozwiqzań do radzenia sobie ze złożonymi problemami społecznymi. Opracowanie odpowiedniego modelu biznesowego przedsięwzięcia społecznego jest kluczowe, ponieważ odpowiedni model o zrównoważonej ofercie wartości może wspierać przedsięwzięcie i skierować je w kierunku samowystarczalności i konkurencyjności. Badania na modelach przedsięwzięć społecznych jak dotad sq ograniczone, tak więc w szczególności innowacje w modelach biznesowych wymagajq większego zainteresowania. Poprzez pogłębione badanie przypadku staramy się rozszerzyć wiedzę, jak modele biznesowe przedsięwzięć społecznych mogq osiqgnqć swój cel, oraz w jaki sposób elementy modelu biznesowego współdziałajq ze sobq. Wyniki badania wskazujq, że rozpoznanie możliwości, po których następuje mobilizacja i integracja innowacyjnych zasobów, może przekształcić się $w$ dobrze funkcjonujqcy biznes-model, który służy do pożqdanych celów, tworzenia wartości społecznej i przyczynić się do osiqgnięcia samowystarczalności. Ponadto, ustalenia właściwych wzajemnych powiqzań pomiędzy elementami modelu biznesowego okazały się wspierać rozwój efektywnego modelu biznesowego przedsięwzięcia społecznego. Słowa kluczowe: przedsiębiorczość społeczna, przedsięwzięcia społeczne, modele biznesowe, tworzenie wartości społecznej.
\end{abstract}

\title{
Biographical notes
}

Dr. Päivi Jokela is a post-doctoral researcher at Turku School of Economics at the University of Turku, Finland. She acquired her PhD in Business Administration at Turku School of Economics, Finland as part of the Valuenetresearch group. Päivi Jokela's current research focuses on sustainability issues in business relationships, social responsibility in entrepreneurship, business models, diaspora networks and firm internationalization. Her research has been published in numerous conference proceedings, in book and journals such as Management International Review and International Journal of Technology Marketing.

Dr. Maria Elo is a post-doctoral researcher at Turku School of Economics at the University of Turku, Finland and a Migration Fellow at the Institute of Migration in Finland. She acquired her PhD in Economics at Åbo Akademi University, Finland as part of the Valuenet-research group. She is the founder and leader of the Diaspora Networks in International Business- research platform and the treasurer of The Society for the Study of Ethnic Relations and International Migration (ETMU). Her current research focuses on international business, diaspora networks and resources, emerging markets, 
and non-prime business. Her work is presented in numerous conferences and workshops, and published in books and journals, such as Industrial Marketing Management and Int. J. Manufacturing Technology and Management. 


\title{
Business Model Adaptation and the Success of New Ventures
}

\section{Bernardo Balboni', Guido Bortoluzzi}

\begin{abstract}
In this study, we explore the connections between business model adaptation and the success of new ventures. We do so by analysing in depth the business model evolution of three new Italian ventures throughout their first years of life. We try to understand if and how the evolution of these firms' business models is connected to their success. Our analysis reveals that adapting their business models was crucial to enabling these firms to survive in extremely dynamic environments. However, it did not fully act as a catalyst for their processes of growth and did not increase their profitability. Keywords: business model adaptation, business model, new ventures, survival, growth.
\end{abstract}

\section{INTRODUCTION}

Many policy makers consider new ventures to be the litmus test for the level of innovativeness and vitality of an economic system and thus give such companies abundant financial support. However, the available empirical evidence shows that a non-negligible amount of new ventures are short lived, do not generate adequate long-term economic returns and do not show substantial growth (Brusoni, Cefis, and Orsenigo, 2006). The managerial literature has identified several drivers of the success of new ventures. Success is defined in the literature as (1) firm survival through the so-called Death Valley; (2) firm growth in revenue and size; and (3) firm profitability (Garnsey, 1998). The three main drivers of success identified in the economic and managerial literature are entrepreneurial factors (the characteristics, attitudes and behaviours of funders), strategic factors (the effectiveness of firms' strategic decisions and the strategic capabilities of firms) and contextual factors (market dynamics, location-specific advantages).

\footnotetext{
1 Bernardo Balboni, PhD, DEAMS Bruno de Finetti University of Trieste, Piazzale Europa, 1 I-34127 Trieste, Italy, tel.: +39040 5587049, e-mail: bernardo.balboni@dreams.units.it.

2 Guido Bortoluzzi, PhD, DEAMS Bruno de Finetti University of Trieste, Piazzale Europa, 1 I-34127 Trieste, Italy, tel.: +39040 5587049, e-mail: guido.bortoluzzi@dreams.units.it.
} 
Some authors claim that, given the increasing complexity of the technological and market environment, firms of every size, age and industry that aim to keep succeeding in their businesses should become more agile in adapting the whole business model of the firm to external contingencies (Chesbrough, 2010; Demil and Lecoq, 2010). The purpose of this study is to explore the connections between business model adaptation (BMA) in new ventures and their success. To do so, we analyse in depth the evolution of the business models of three new ventures throughout their first years of life and try to understand if and how the evolution of their business models is connected to their success. Our analysis reveals that, in all the cases analysed, adapting the business model was crucial to enable these firms to survive in extremely dynamic environments. However, we cannot fully claim that the innovation of the business model acts as a catalyst of their growth process or made them highly profitable. Thus, contrary to the well-established idea that initial business model of innovative start-ups reflects their market potential, our findings emphasise the importance of BMA as a capability which enables new venture survival. Our evidence cannot support that, by adapting the business model, new ventures can accelerate their growth or become highly profitable.

\section{Background}

What increases new ventures' chances of success? This question motivates a considerable amount of empirical research on the conditions that favour the survival and growth of new firms (Delmar, Davidsson and Gartner, 2003; Gilbert, McDougall and Audretsch, 2006). Emphasis is placed on many determinants, including the profile of the founding entrepreneur(s), the characteristics of the business environment and the type of strategies implemented (Song, Podoynitsyna, Van Der Bij and Halman, 2008). Without intending to be exhaustive, we identify three main schools of thought contributing significantly to a better understanding of this topic: (1) entrepreneurial factors; (2) contextual factors; and (3) strategic factors.

Entrepreneurial factors include the personal attributes, mental attitudes and individual skills of the founding entrepreneur(s) (Carland, Hoy and Carland, 1988; Terpstra andOlson, 1993; Bhidé, 2000). The founders' personal characteristics are important in driving the growth of new ventures for several reasons (Amorós, Bosma and Kelley, 2014). First, the individual traits of the founders can shape the innovative culture and strategic behaviour of the firm, leading the new venture along highly challenging but also highly rewarding strategic paths (Mullins, 1996; Baum, Locke and Smith, 2001). Second, founders' education and prior industry experience can provide new 
ventures with a set of knowledge-based assets (e.g. market knowledge, knowledge of competitive dynamics, suppliers and distributors) that can significantly speed firm growth (Birley, 1985; Duchesneau and Gartner, 1990; Hansen, 1995; Sapienza and Grimm, 1997; Stuart and Abetti, 1986; Watson, Steward and Barnir, 2003). Third, external investors often assess the potential of a new venture by considering the founders' individual attributes and are more inclined to support ventures that can guarantee more robust foundations in this regard (Colombo and Grilli, 2005). The same trends hold true for the founding team, which is the topic of analysis in several studies (Eisenhardt and Schoonhoven, 1990; Feeser and Willard, 1990; Zucker, Darby and Brewer, 1998).

Three perspectives are widely adopted in the analysis of contextual factors. First, an emphasis on industry structure and market dynamics dominates in strategic studies as the firm's moves are typically assumed to be triggered by the opportunities (and threats) emerging from the market and to be favoured (or constrained) by the structural characteristics of the industry to which a firm belongs (Davidsson, 1989a, 1989b; Stevenson and Jarillo, 1990). Thus, in these studies, it is assumed that certain markets and industries offer more favourable conditions than others for the success of a new venture (Audretsch, 1995; Vivarelli and Audretsch, 1998). The second perspective focuses on the role of institutional factors (e.g. regulations, culture, norms, infrastructure) in supporting or undermining success. Representative studies from this perspective include the work of Fritsch (1997) and Djankov, McLiesh and Ramalho (2006), who observe that firms generally grow more and faster in countries (or regions) characterised by efficient markets and effective financial and labour regulations. A third perspective considers the specific location of new firms and the characteristics of the local environment. This perspective is highly popular among regional economists, geographers and industrial economists and is adopted in an impressive amount of studies on related concepts, such as industrial clusters (Porter, 1998), industrial districts (Becattini, 1990) and regional innovation systems (Doloreux, 2003).

Local firms benefit from these contextual forces, making location itself a key determinant of firms' performance in survival, growth and profitability. Under certain conditions, a magnet effect is exerted (new suppliers, clients, firms and talents are drawn to the area) which reinforces itself over time (Thakor and Lavack, 2003). Silicon Valley in California is among the representative cases. In the same vein, Glaeser Kallal, Scheinkman and Shleifer (1992) claim that proximity and location play an important role in enabling the diffusion of knowledge-especially tacit knowledge-across firms in a spatially bounded region (Audretsch and Feldman, 1996; Jaffe, 1989; Jaffe, Trajtenberg and Henderson, 1993). Strong inter-firm networks 
which enable knowledge spill-over offer high-tech firms a higher chance of success (Raz and Gloor, 2007) by providing them with access to resources not otherwise available (Witt, 2004). Finally, other scholars emphasise the role played by firms' market strategies and strategic capabilities to explain the growth variation among new ventures (Almus and Nerlinger, 1999; Bloodgood, Sapienza and Almeida, 1996; Li, 2001; Marino and De Noble, 1997; Siegel, Siegel and Macmillan, 1993; Smallbone, Leigh and North, 1995; Zahra and Bogner, 2000).

In an attempt to define the characteristics of market strategies that distinguish high- and low-growth companies, Siegel et al. (1993) find that small, young small companies suffer from resources starvation and so perform better as they focus all their efforts on achieving well-defined goals. Kaplan, Sensoy and Stromberg (2009) present an interesting study. The authors analyse a sample of successful venture-capital-financed companies and examine how firm characteristics evolve from the early business plan to the initial public offering (IPO). Kaplan et al. (2009) conclude that external investors should place more weight on start-ups' business strategy (the horse, in the metaphor used by the authors) than on their management team (the jockey) as having good strategies seems to pay off much more than having good people to carry them out. The Stanford Project on Emerging Companies supports a similar view and suggests that a good business idea and non-human capital assets are relatively more important to the success of a start-up firm than the characteristics of the management team (Baron and Hannan, 2002; Baron, Hannan and Burton, 1999; Beckman and Burton, 2008).

Further studies have attempted to combine the strategic view of the firm with other theoretical perspectives, such as entrepreneurial theory and firm organisational theory, to achieve a more comprehensive explanation of the success of new ventures (e.g. Baum et al., 2001; Chrisman, Bauerschmidt and Hofer, 1998; Sandberg and Hofer, 1987). Much of this literature does not take a completely strategic perspective but, instead, supports a contingency approach in which it is assumed that success is mostly attributable to the fit between internal factors (e.g. the firm's organisational structure and strategies) and characteristics of the external environment (Eisenhardt and Schoonhoven, 1990; Feeser and Willard, 1990).

Regarding strategic capabilities, much of the research on new ventures has focused on the right set of firm-level resources (physical, human and organisational) needed by new ventures to face situations of high market and technological instability (i.e. Teece, Pisano and Shuen, 1997; Eisenhardt and Martin, 2000). In this research stream, the success of new ventures has been attributed mostly to firms' ability to develop a proper internal base 
of resources and competences and to access external resources through networking (Lee, Lee and Pennings, 2001; Heirman and Clarysse, 2004; McDougall, Covin, Robinson and Herron, 1994; Zahra and Bogner, 2002; Zahra, Matherne and Carleton, 2003). The research by Lee et al. (2001) follows this direction and shows that internal capabilities are important predictors of a start-up's growth potential, while among external networks, linkages to venture capital companies are significantly. However, research on startups has neglected the dynamic capability view of the firm (Amit and Zott, 2001; Mezger, 2014). According to Eisenhardt and Martin (2000), dynamic capabilities are 'the organisational and strategic routines by which firms achieve new resource configurations as markets emerge, collide, split, evolve and die' (p. 1107). Teece (2007) describes these routines as meta-capabilities that allow firms to sense market opportunities (and threats), rapidly seize such opportunities and reconfigure their internal bundle of resources and competences in a coherent way. By sharpening dynamic capabilities, new ventures can easily recognise and rapidly exploit profitable market opportunities and avoid remaining stuck with unprofitable business ideas. Additionally, new ventures that rapidly reconfigure their assets are expected to create a more favourable alignment between external (opportunities and threats) and internal (resources and competences) environmental conditions, increasing their ability to grow faster than other firms.

\section{Business model adaptation}

Some recent works shift attention to the concept of the business model, which can provide a coherent framework for explaining how new business ideas are converted into economic value (e.g. Chesbrough and Rosenbloom, 2002; Onetti, Zucchella, Jones and McDougall-Covin, 2012). Despite the lack of a consensus definition of a business model, we can state that the concept generally refers to a set of decisions that relate to a firm's market strategy, organisational structure and the activities it performs both inside and within the business environment through a network of transactions. This concept builds on the literature on business strategy, organisation design, transaction theory and business networks.

In seminal work on business models, Amit and Zott (2001) observe that the business model concept is close to but does not fully coincide with the strategy approach. Indeed, firms compete through their business models, but while the strategy approach emphasises the competitive dimension (value capture), the business model heavily stresses cooperation, partnerships, joint value creation and customer value proposition. Amit and Zott (2001) identify four dimensions of the business model that can influence the value 
creation (and, thus, the growth performance) of a new venture: (1) the business model's degree of novelty; (2) customers' and partners' degree of lock-in to a specific business model; (3) the available complementarities (the possibility of offering a bundle of different products or services through the same business model); and (d) the level of transactional efficiency. This business model concept encompasses and goes beyond strategy formulation (Zott and Amit, 2007, 2008). Casadesus-Masanell and Ricart (2010) observe that the business model reflects a realised strategy and pertains more to strategy execution than to strategy formulation.

Pisano (2006, 2010) and Braguinsky, Honjo, Nagaoka and Nakamura (2010) address the challenge of designing viable business models for scienceand research-based new ventures. Science-based businesses confront three fundamental challenges: 1 ) the need to encourage and reward profound risk taking over long time horizons (the risk management problem); 2) the need to integrate knowledge across highly diverse disciplinary bodies (the integration problem); and 3) the need to accumulate learning (the learning problem). Although each of these challenges-risk, integration, and learning-are present to varying degrees in most business settings, they appear in far greater force and often simultaneously in science-based businesses (Pisano, 2010). Thus, science appears to be a specific environment in which business organisations must develop different and specific models to perform their activities profitably. In other words, we can expect that viable science-based businesses need to design and, over time, adapt business models that are not merely replicas of those prevalent in traditional business settings.

These new business models might also show radical differences at the entrepreneurial level. Indeed, Braguinsky et al. (2010) challenge the conventional view of science-based businesses, which focuses on the inseparability of the roles of the inventor and the Schumpeterian entrepreneur who implements the business in practice. Similar dynamics are observed in the cases of new high-tech ventures. Onetti et al. (2012) emphasise that, today, such firms are forced to develop a broad strategic vision and global competitive strategies and capabilities. Most important to these firms' growth is an 'effective business model design, where decisions about core activities and where to focus investments are interconnected to decisions about location of activities, and about inward and outward relationships with other players' (p. 363).

Most scholars recognise that firms are continuously subjected to external environmental pressures and need to adapt their business models to preserve their relevance (Cavalcante, Kesting and Ulhøi, 2011; Wirtz, Schilke and Ullrich, 2010). In this context, Chesbrough (2010) finds, based on continuous experimentation, that BMA is crucial for new ventures. This experimental 
process leverages firms' dynamic capabilities and enables them to develop novel value offerings, implement new value chain structures and reconfigure their revenue models (Chesbrough, 2010). A new venture seeks a scalable, repeatable, profitable business model (Blank and Dorf, 2012). Therefore, the ability to dynamically adjust the business model to changing environmental conditions and emerging market opportunities is a key capability expected to increase a start-up's likelihood of survival in the short term and to support its growth in the medium and long term.

Based on this literature, this study addresses the relationship between BMA and the success of new firms. Responding to an empirical gap in the literature, we aim to understand whether the dynamic adaptation of the business model acts a clear, unambiguous driver of the success of the new venture. To do so, we proceed from the assumption that BMA is reflected positively in the survival, growth and profitability of the new venture. New ventures that dynamically adapt and re-configure their business model to ensure alignment and coherence with the competitive landscape and market opportunities and feedback should have higher chances to succeed. Therefore, we test the following research hypothesis:

BMA is positively connected with the success-survival, growth and profitability - of the new venture.

\section{MetHOdOLOGY}

This paper is based on a multiple case study design (Yin, 2009). Given the lack of rigorous, theoretically guided and empirically based approaches in research on BMA (Zott, Amit and Massa, 2011), we adopt an inductive methodology to analyse and compare a selected number of innovative new ventures. Such research is especially useful as it allows making comparison between BMA processes and, thus, is likely to enable the development of theory about BMA and its relationship to the success of new ventures (Eisenhardt and Martin, 2000; Yin, 2009).

\section{Selection of case studies}

Preliminary unstructured interviews with external experts were conducted to select relevant case studies. We interviewed the managing directors of three business incubators and the investment director of a venture capital fund. Their knowledge about the local start-up scene helped us pre-select five companies with common features: (1) survived the death valley; (2) showed growth over time; and (3) underwent several significant BMA processes. We did not look specifically for gazelle firms as we were not interested in understanding how outliers behave. We specifically asked about 
firms that could be considered representative of a normal, successful startup firm, leaving it to our interlocutor to define such a term. All the firms were approached in the fall 2014. Three accepted being interviewed, one declined for confidentiality reasons, and one postponed the interview. The three start-ups selected were founded in the 2008-2010 period, belong to different sectors and include external investors in their equity capital. Table 1 provides detailed information about the companies.

Table 1. Case studies: selected data

\begin{tabular}{|c|c|c|c|}
\hline & MilkyWay & ModeFinance & O3 Enterprise \\
\hline Year of establishment & 2011 & 2010 & 2008 \\
\hline Location & $\begin{array}{l}\text { Knowbel Start-ups } \\
\text { Incubator, Modena, } \\
\text { Italy }\end{array}$ & $\begin{array}{l}\text { Area Science Park, } \\
\text { Trieste, Italy }\end{array}$ & $\begin{array}{l}\text { Area Science Park, } \\
\text { Trieste, Italy }\end{array}$ \\
\hline Sales (Euro) (2013) & 125,000 & 294,000 & 479,000 \\
\hline Employees (2013) & 7 & 5 & 6 \\
\hline $\begin{array}{l}\text { Total Investments } \\
\text { (Euro) (2013) }\end{array}$ & 345,000 & 406,000 & 446,000 \\
\hline External Investors & $\begin{array}{l}\text { TT Venture (venture } \\
\text { capital fund) } \\
\text { Atlante Seed ( venture } \\
\text { capital fund) }\end{array}$ & $\begin{array}{l}\text { Friulia S.p.A. (venture } \\
\text { capital fund) } \\
\text { C.G.N. Servizi } \\
\text { (customer/reseller) }\end{array}$ & $\begin{array}{l}\text { Insiel Mercato S.P.A. } \\
\text { (customer/reseller) }\end{array}$ \\
\hline
\end{tabular}

Source: Aida Database by Bureau Van Dijk.

\section{Data collection}

Data on these new ventures were collected through three main sources: (1) direct, semi-structured interviews with the founders/entrepreneurs; (2) informal follow-ups through e-mails and virtual meetings; and (3) collection of secondary data, including both public (e.g. public annual reports, articles in business newspapers and blogs) and internal materials. Data sources were triangulated to mitigate the risk of informant bias (Gibbert et al., 2008).

At least two interviews were conducted with each company to describe the firms' current and initial business model configurations and the drivers that led to BMA. All interviews took place between July and October 2014, and each lasted 60-120 minutes. The interviews were taped, transcribed literally and reviewed by the interviewees to improve accuracy (Huber and Power, 1985).

The interviews were based on the framework provided by Morris, Schindehutte and Allen (2005), in which a business model refers to a set of six fundamental components: 1 ) value offering; 2 ) market segments; 3 ) core 
competences; 4) competitive strategy (external positioning, in the original formulation of Huber and Power, 1985); 5) cost and revenue model; and 6) entrepreneurs' motivations. The value offering is related to the nature of the product or service mix and the process of value transfer to the client. Market segments refer to the nature and scope of the market to which the firm's offerings are addressed. Core competences are the internal resources and capabilities which should enable a firm to perform better than its competitors. Competitive strategy refers to how the firm achieves advantages over its competitors by relying on these core competencies. The cost and revenue model reflects the economic logic of expenses, earnings and profits. Finally, entrepreneurs' motivations describe the entrepreneurs' ambitions regarding time, size, and business scope.

Informants were asked first about the actual configuration of these six components of their business model. The actual business model configuration was used as a starting point to retrieve, through a retrospective approach, the changes which occurred in the business model from the foundation of the firm and the reasons behind these changes. The laddering technique was used to capture entrepreneurial motives and goals connected to the business model reconfiguration.

\section{Data analysis}

First, interviews were coded and analysed by two independent researchers, focusing on the six fundamental components of business model architecture (Strauss and Corbin, 2008). Next, the coded materials were combined and refined if any deviations occurred. Second, a within-case analysis was developed for each case based on the six fundamental components of business model architecture. This within-case analysis permitted clarifying the drivers that led to BMA (Yin, 2009). Third, to identify a series of common BMA patterns, a cross-case analysis was developed (Eisenhardt and Graebner, 2007). Iterating between theory and multiple case analysis clarified the theoretical argumentation (Eisenhardt, 1989).

\section{RESULTS}

This section presents the insights derived from the analysis of each case, the within-analysis and cross-case analysis in relation to the literature on BMA.

\section{MilkyWay}

MilkyWay is a new Italian venture which focuses on the design, manufacture and online sale of trial bikes and action-sport equipment (Table 2). The firm was 
established in 2010 by a mechanical engineer (Jacopo Vigna) with experience in the biomedical field and the racing departments of two leading motorbike manufacturers. The start-up enjoys the capital provided by an angel investor and the support of a technology-transfer centre at the University of Modena. In 2012, Vigna was selected to participate in the SeedLab acceleration program, which enabled better identifying and improving MilkyWay's actual business model. In 2013, two venture capital funds invested a total of EUR 720,000 in the company's equity.

MilkyWay's initial business idea was to transfer technological innovations from the motorsports industry to the trial bike sector. Bikes and bike parts and components had been addressed to a specific tribe (trial bikers) and sold through an e-shop. To create a community-based marketplace and expand long-tail demand, MilkyWay became a reseller of products and devices connected to action sports (e.g. skating, surfing, kite-surfing, parkour) and started to invest in the development of a proprietary platform (community + e-commerce) in 2012. As of 2014, the overall assortment had 31 categories and more than 16,000 references. The proportion of MilkyWay's total sales accounted for by assembled product has diminished. The initial target market was trial-bikers, but this global niche is too narrow to support a real growth. MilkyWay has progressively broadened its target market into action sports lovers/addicts. The basic idea is to exploit long-tail demand composed of many sub-segment and cross-selling opportunities (extreme athletes usually practice different disciplines). Today, trial bikes still contribute $50 \%$ of total sales.

The company initially opted to offer unique high-tech products (assembled bikes and special components) at premium prices but recently aligned the price positioning of resold items with its competitors (e-shops). MilkyWay first focused on its technological competences and founder's networking capabilities. The investment of venture capital funds significantly changed the internal organisational structure (some roles are internalised, and the firm has 10 employees), creating the possibility to focus on development of the internal platform (e-commerce + e-community). E-commerce serves as the firm's main (and unique) source of revenue. Its customer base has expanded significantly during the past two years. Customer loyalty and sales per customer remain low because of difficulties in platform implementation. Initially driven by the search for excellence and the desire to create superior products and components, the firm's growth orientation is reflected in the search for a scalable business model and the development of a user-oriented platform (e-shop + community). 


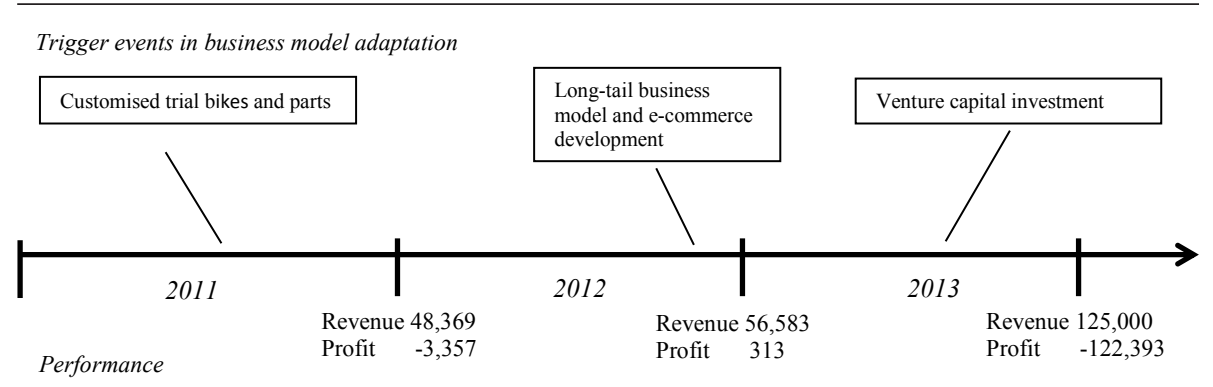

Figure 1. MilkyWay business model adaptation and performance (Euro)

\section{ModeFinance}

ModeFinance is an Italian venture in the financial consulting sector. Operating as a university research project since 2003 , the company was established in 2009 and is in the business incubator of Area Science Park in Trieste (Table 3 ). The business is based around proprietary technology for credit risk analysis. The firm provides clients (mostly importantly, firms, banks and insurance companies) with various reports evaluating the overall economic sustainability and creditworthiness of firms.

Initially, the company produced credit reports for a unique client that was also its unique supplier. This client remains a multinational company offering credit rating and business intelligence services and databases. ModeFinance uses the data provided by this multinational to generate credit rating reports which the multinational firm resells to its clients. This activity remains part of ModeFinance business and accounts for some $30 \%$ of its actual turnover.

ModeFinance soon decided to develop a market for its proprietary products, simple software targeted at banks and bigger firms to help them analyse the creditworthiness of their clients. The proportion of the company's total revenues from this activity remains marginal. Since 2010, the company has sold credit reports directly to big firms. The majority of ModeFinance's revenues comes from this activity, which has been highly standardised. The firm also produces more comprehensive reports, combining qualitative (strategic, organisational) and quantitative (financial) data and information on single firms, especially in preparation for merger and acquisition processes. Such reports require a significant amount of human intervention. In 2012, the company launched an App for mobile devices (S-peek) that allows users to obtain standardised credit reports. The product is intended to increase the business's scalability but, so far, generates only a marginal portion of the company's total revenues. 
Excluding the multinational company that initially supported the new venture and remains its most important client, ModeFinance does not target a unique market. Clients vary from medium-sized to big firms, from financial intermediaries to business consultants. The company directly serves approximately 100 customers and another 300 through the intermediary of the partner multinational. The S-peek app has been downloaded by thousands of users worldwide. No information exists on these users.

To compete in a sector dominated by big players, ModeFinance has adopted a cost-leadership strategy. Its prices are, on average, 30\% lower than competitors. To sustain this price positioning, the company has been forced to gradually standardise its offerings. This strategy has not changed over time.

So far, the company has been growing mostly due to its technological (the development and refinement of its rating algorithm) and supply chain (scouting and management of data and information suppliers in foreign markets) capabilities. Its weak sales and marketing capabilities are its Achilles's heel and main constraint on growth.

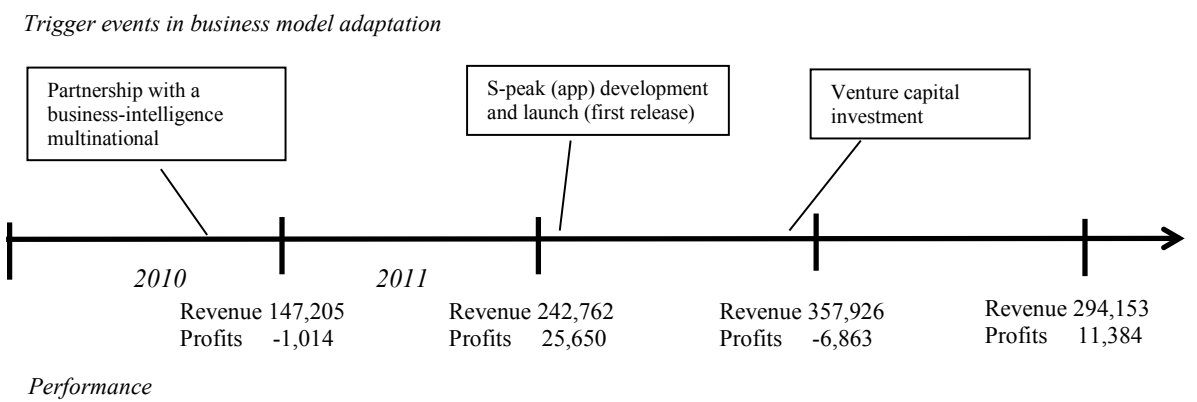

Figure 2. ModeFinance business model adaptation and performance (Euro)

ModeFinance's revenue streams are quite diversified. It obtains license fees from its historical partner, receives cash from direct clients and collects revenues from its app users (cut by the percentage due to the platform's owners). Occasionally, the firm also looks for extra revenues from statefunded research projects. In 2013, these revenues provided approximately $25 \%$ of the firm's total turnover.

The firm directly manages all its core activities. It limits outsourcing to specific non-core, business-related services, such as accounting. The entrepreneurs have been systematically oriented to the growth of the business since its founding. 


\section{O3 Enterprise}

O3 Enterprise is an Italian company offering digital imaging services in the medical sector (Table 4). It provides solutions for the visualisation and management of patients' clinical data. The idea originated from an academic research project in 2004, and the company was established in January 2008.

The company started as a provider of open-source solutions for the visualisation of clinical data (especially images) of patients. The importance of the product in the company's offerings was prominent. Recently, the company completely revised its strategy to offer a cloud-based solution for archiving, visualising and reporting clinical data (images, videos and signals). The importance of the main product has diminished, while the importance of and the revenues from complementary services, such as project design, installation and maintenance, have increased.

Starting with a partially incorrect definition of its target market (too broad and partly inaccessible because of regulatory constraints), 03 Enterprise has progressively focused on the medium-sized, private hospitals market. It has started, in parallel, a process of progressive internationalisation. To quickly obtain market share, the company initially opted for penetration prices (up to $50 \%-60 \%$ below its competitors). The prices, especially for ancillary

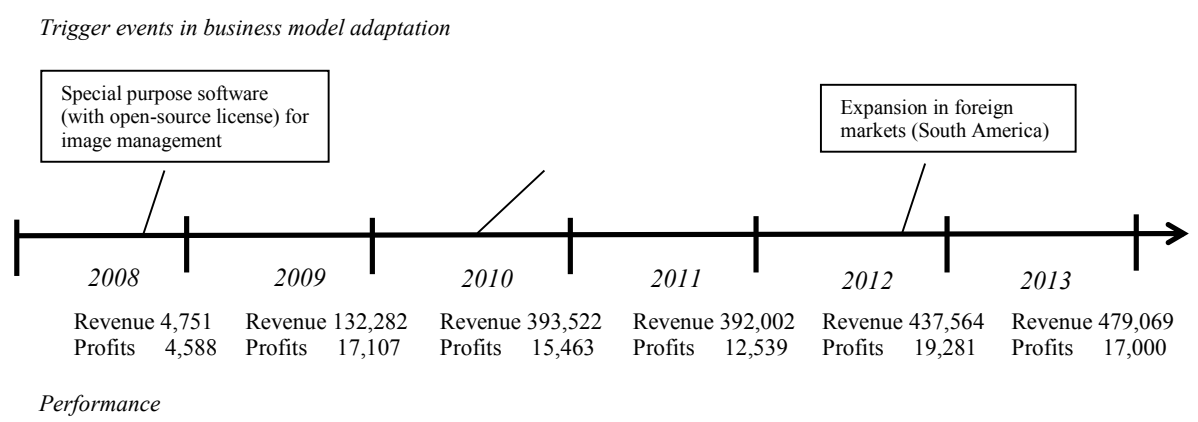

Figure 3. 03 business model adaptation and performance (Euro)

As the chief executive officer states, 'the first years were the ones of technological exploration. Now have come the years of market exploitation'. Indeed, the company grew around its technological capabilities in the first years. Its turning point can be identified as 2013, when 03 Enterprise decided to push on the sales accelerator, hiring a sales manager who raises revenues from foreign markets. 
Despite not significantly expanding its client portfolio during the 2008-2013 period, the company could increase its revenues by achieving a higher penetration with each client. Today, most revenues come from a few big clients. The company has been oriented to the systematic growth of its business since market entry. This orientation has never changed.

\section{Discussion}

The three cases examined in the previous section provide a quite rich array of BMA processes. Looking at common patterns among the three, five typical paths of BMA can be identified. First is the standardisation and modularisation of products and services, particularly serial solutions, for transaction efficiency gains (Amitt and Zott, 2001; Brusoni and Prencipe, 2001). MilkyWay shifted its offerings from customised trial bikes and parts and components to standardised products and action sports equipment (skating, surfing, kite-surfing, parkour) to seize the opportunities in a wider market. Sensing the opportunity to simplify its products and to commoditise mass-market access to financial information, ModeFinance developed an app for mobile devices (S-peek) and expressed the intention to further enlarge its assortment of standardised products through a partial reconfiguration of its internal capabilities. 03 Enterprise completely revised its offerings and coherently reconfigured its capabilities to move to a cloud-based solution for archiving, visualising and reporting clinical data (images, videos and signals).

For all the firms, the standardisation and modularisation process is difficult. Indeed, MilkyWay faces several technical problems in developing its e-shop and converting community members into effective customers. The first release of the app launched by ModeFinance was improved several times to accelerate its adoption by final customers. 03 Enterprise's standardisation of software required a substantial change in its relational approach to its main customers. These implementation problems affect the performance achieved by the three firms: positive revenue growth is associated with limited profitability.

A second common pattern is related to the creation of solutions. The three cases suggest that these three innovative ventures exploit the potential for value creation by offering customers bundles of complementary products and services (Amit and Zott, 2001). These bundling solutions sometimes rely on both vertical complementarities (products and services characterised by high vertical integration in the value chain) and horizontal complementarities (different solutions connected by cross-selling opportunities). After sensing a clear opportunity in the market, MilkyWay developed a wide assortment of solutions to exploit horizontal cross-selling opportunities in the action sports 
segment, where extreme athletes usually practice different disciplines. ModeFinance broadened its product assortment to explore new segments (small and medium enterprises) and better fulfil the horizontal needs of its main customers (banks). 03 Enterprise quickly revised its product strategy and offers a cloud-based integrated solution for archiving, visualising and reporting clinical data which is connected to other complementary vertical services, such as project design, installation and after-sales. The three firms implemented these moves in an agile way. In this sense, the firms' dynamic capabilities have been critical in keeping them alive and kicking in three highly dynamic business environments. However, the limited profits earned by the firms reveal that the exploitation of cross-selling opportunities through solutions building needs a long-term approach.

A third pattern is the fine-tuning of target markets. The observed firms do so continuously, with the aim to meet the needs expressed by different customer segments (Demil and Lecoq, 2010). Firms also focus on international markets, customers and niches and multiple distribution channels. For instance, MilkyWay has enlarged its target market from trial-bikers to actionsports lovers to exploit long-tail demand composed of many sub-segments. O3 Enterprise has progressively shifted its focus to the broader target market of medium-sized private hospitals. Simultaneously, it has started a process of progressive internationalisation through the establishment of a new channel of foreign distributors. ModeFinance has worked hard to escape the deadly hug of a single customer and uses three channels to distribute its services. The fine-tuning of these segmentation strategies has a direct effect on revenue growth but limited effect on profitability. These three new ventures expand and penetrate new markets at the expense of their overall margins.

The fourth pattern is the development of market-oriented competences. Three firms supplement their initial focus on technological know-how and product development capabilities with a strong effort directed to develop sales and marketing competences to support their competitive strategies and sustain their growth (Colombo and Grilli, 2005). MilkyWay invests in the implementation of an integrated platform (e-commerce and e-community) focusing on the enhancement of the user experience. After growing mostly through technological and supply chain capabilities, ModeFinance directs its attention to sales and marketing competences. 03 Enterprise attempts to move from technological exploration to market exploitation and has hired a sales manager to boost revenue from foreign markets. The reconfiguration of the companies' (marketing) capabilities is neither simple nor automatic. Their size liability hinders them from effectively developing new marketing competences. Closing the gap between the increasing complexity of markets and firms' limited internal ability to sense and seize new opportunities 
requires time. Consequently, the benefits for growth and profitability from reconfiguring companies' assets and competences remain quite limited in all the cases examined.

Finally, we see the fifth pattern of attracting external investors. The firms' commitment to growth attracts external investors (Davila, Foster and Gupta, 2003). In particular, MilkyWay acquired a business angel's investment and participated in a first-round of investment with two venture capital funds. ModeFinance's orientation to systematic business growth has attracted external investors (including a regional investment fund and a private firm). 03 Enterprise's strong entrepreneurial growth efforts have attracted an external industrial investor (a major customer who invested in the firm). So far, the results show that venture capital investment in the early stage of a firm does not imply the direct increase of the revenue growth rate and profitability. Venture capital allows new ventures to focus on the achievement of longterm performance, rather than short-term results.

\section{CONCLUSION}

The three start-ups examined are all involved in significant BMA processes. We can claim that, since their establishment, they have sought to improve their business models to ensure a better match with market demand and technological advancements. More specific customer needs, market misalignments and the ability to sense new technological potential have been the major common drivers of the dynamics of these firms' BMA processes (Mezger, 2014). Our findings are contrary to the well-established idea that innovative start-ups' initial business model sets their market potential. The cases of MilkyWay, ModeFinance and $\mathrm{O} 3$ Enterprise reveal that the long, complex, risky BMA process is as important as innovation in determining at least the survival of a new firm, which is the first step towards success. This process is far from complete at all the examined new ventures as they are still involved in the complex process of reconfiguring their key capabilities, including sales and marketing capabilities (Teece, 2010; Zahra, 2008).

Despite some difficulties in fine-tuning their ideas with their target markets in the first years since establishment, these firms can continuously spot new opportunities, effectively manage external risks and significantly evolve their internal resource base. Are these efforts enough to achieve growth and profitability? They are in part but not completely. Indeed, the main contribution of this study is to show that, in all the cases analysed, BMA is critical to guaranteeing firm survival in especially tough environments. However, we cannot claim that the results fully support the hypothesis that BMA is key to determining the growth and success of start-ups. The other 
perspectives presented in the literature review complement our findings and help better understand what drives (or partly drives) the growth of these firms. In particular, we find that internal capabilities (especially sales and marketing capabilities) and external connections play key roles.

This study, of course, has many limitations, of which the limited amount of companies studied is the most significant. Although qualitative, this study could have obtained a richer picture through the analysis of additional cases. The selection procedure used to identify the three cases involved (using experts in the field) could lead to biased selection. Despite a lack of spectacular results, the three firms analysed perform well in the market and might not represent the average start-up which struggles to survive and to grow. Future studies should address this topic using a quantitative approach, accounting for all the limitations related to the operationalisation of such a complex concept as that of the business model.

\section{References}

Almus, M., Nerlinger, E.A. (1999). Growth of new technology-based firms: Which factors matter? Small Business Economics, 13(2), 141-154.

Amit, R., Zott, C. (2001). Value creation in e-business. Strategic Management Journal, 22(6-7), 493-520.

Amoros, J.E., Bosma, N., Kelley, D. (2014). Global Entrepreneurship Monitor: 2013 Executive Report. London, GB: London Business School, and Wellesley, MA: Babson College.

Audretsch, D.B. (1995). Innovation and industry evolution. Cambridge, MA: MIT Press.

Audretsch, D.B., Feldman, M.P. (1996). R\&D spillovers and the geography of innovation and production. American Economic Review, 86(3), 630-640.

Baron, J.N., Hannan, M.T. (2002). Blueprints for success in high-tech start-ups. California Management Review, 44(3), 8-36.

Baron, J. N., Hannan, M.T., Burton, M.D. (1999). Building the iron cage: Determinants of managerial intensity in the early years of organizations. American Sociological Review, 64(4), 527-547.

Baum, J., Locke, E., Smith, K. G. (2001). A multidimensional model of venture growth. Academy of Management Journal, 44(2), 292-303.

Becattini, G. (1990). The Marshallian industrial district as a socio-economic notion. In F. Pyke (Ed.), Industrial districts and inter-firm cooperation in Italy (pp. 37-51). Geneva: International Institute for Labor Studies.

Beckman, C.M., Burton, M.D. (2008). Founding the future: Path dependence in the evolution of top management teams from founding to IPO. Organization Science, 19(1), 3-24.

Bhidé, A. (2000). The origin and evolution of new businesses. Oxford: Oxford University Press. 
Birley, S. (1985). The role of networks in the entrepreneurial process. Journal Business Venturing, 1(1), 107-117.

Blank, S. G., Dorf, B. (2012). The startup owner's manual: The step-by-step guide for building a great company. Pescadero, CA: K\&S Ranch.

Bloodgood, J.M., Sapienzan H.J., Almeida, J.G. (1996). The internationalization of new high-potential U.S. ventures: Antecedents and outcomes. Entrepreneurship Theory and Practice, 20(4), 61-76.

Braguinsky, S., Honjo, Y., Nagaoka S., Nakamura, K. (2010). Science-based business: Knowledge capital or entrepreneurial ability? Theory and evidence from a survey of biotechnology start-ups, IIR Working Paper Series, WP\#10-05. Institute of Innovation Research, Hitotsubashi University.

Brusoni S., Cefis E., Orsenigo L. (2006). Innovate or die. A critical review of the literature on innovation and performance, CESPRI Working Paper, 179.

Brusoni, S., Prencipe, A. (2001). Unpacking the black box of modularity: Technologies, products and organizations. Industrial and Corporate Change, 10(1), 179-205.

Carland, J. W., Hoy, F., Carland, J. A. (1988). Who is an entrepreneur? Is a question worth asking. American Journal of Small Business, 124(2), 3339.

Casadesus-Masanell, R., Ricart, J.E. (2010). From strategy to business models and onto tactics. Long Range Planning, 43(2), 195-215.

Cavalcante, S., Kesting, P., Ulhøi, J. (2011). Business model dynamics and innovation: Re-establishing the missing linkages. Management Decision 49(8), 1327-1342.

Chesbrough, H. (2010). Business model innovation: Opportunities and barriers. Long Range Planning, 43(2), 354-363.

Chesbrough, H., Rosenbloom, R.S. (2002). The role of the business model in capturing value from innovation: Evidence from Xerox Corporation's technology spin-off companies. Industrial and Corporate Change, 11(3), 529-555.

Chrisman, J., Bauerschmidt, A., Hofer, C.W. (1998). The determinants of new venture performance: An extended model. Entrepreneurship: Theory and Practice, 23(1), 5-30.

Colombo, M.G., Grilli, L. (2005). Founders' human capital and the growth of new technology-based firms: A competence-based view. Research Policy, 34(6), 795-816.

Davidsson, P. (1989a). Continued entrepreneurship and small firm growth. Stockholm: Stockholm School of Economics.

Davidsson, P. (1989b). Entrepreneurship-and after? A study of growth willingness in small firms. Journal of Business Venturing, 4(3), 211-226.

Davila, A., Foster, G., Gupta, M. (2003). Venture capital financing and the growth of startup firms. Journal of Business Venturing, 18(6), 689-708.

Delmar, F., Davidsson, P., Gartner, W. B. (2003). Arriving the high-growth firm. Journal of Business Venturing, 18(2), 189-216. 
Demil, B., Lecocq, X. (2010). Business model evolution: In search of dynamic consistency. Long Range Planning, 43(2), 227-246.

Djankov, S., McLiesh, C., Ramalho, R.M. (2006). Regulation and growth. Economic Letters, 92(3), 395-401.

Doloreux, D. (2003). Regional innovation systems in the periphery: The case of the Beauce in Québec Canada. International Journal of Innovation Management, 7(1), 67-94.

Duchesneau, D., Gartner, W. (1990). A profile of new venture success and failure in an emerging industry. Journal of Business Venturing, 5(5), 297312.

Eisenhardt, K.M. (1989). Building theory from case study research. Academy of Management Review, 14(4), 532-550.

Eisenhardt, K.M., Graebner, M.E. (2007). Theory building from cases: opportunities and challenges. Academy of Management Journal, 50(1), 25-32.

Eisenhardt, K.M., Martin, J.A. (2000) Dynamic capabilities: What are they? Strategic Management Journal, 21(10/11), 1105-1121.

Eisenhardt, K.M., Schoonhoven, C.B. (1990). Organizational growth: Linking founding team, strategy, environment, and growth among us semiconductor ventures 1978-1988. Administrative Science Quarterly, 35(3), 504-529.

Feeser, H.R., Willard, G.E. (1990). Founding strategy and performance: A comparison of high and low growth high-tech firms. Strategic Management Journal, 11(2), 87-98.

Fritsch, M. (1997). New firms and regional employment change. Small Business Economics, 9(5), 437-448.

Garnsey, E. (1998). A theory of the early growth of the firm. Industrial and corporate change, 7(3), 523-556.

Glaeser, E., Kallal, H., Scheinkman, J., Shleifer, A. (1992). Growth of cities. Journal of Political Economy, 100(6), 1126-1152.

Gibbert, M., Ruigrok, W., Wicki, B. (2008). What passes as a rigorous case study? Strategic Management Journal, 29(13), 1465-1474.

Gilbert, B.A., McDougall, P.P., Audretsch, D.B. (2006). New venture growth: A review and extension. Journal of Management, 32(6), 926-950.

Goffin, K., Mitchell R. (2005). Innovation management. London: Pearson.

Hansen, E.L. (1995). Entrepreneurial networks and new organizational growth. Entrepreneurship: Theory and Practice, 19(4), 7-19.

Heirman, A., Clarysse, B. (2004). How and why do research-based start-ups differ at founding? A resource-based configurational perspective. The Journal of Technology Transfer, 29(3-4), 247-268.

Huber, G. P., Power, D.J. (1985). Retrospective reports of strategiclevel managers: Guidelines for increasing their accuracy. Strategic Management Journal, 6(2), 171- 180.

Jaffe, A.B. (1989). Real effects of academic research. American Economic Review, 79(5), 957-970. 
Jaffe, A.B., Trajtenberg, M., Henderson, R. (1993). Geographic localization of knowledge spillovers as evidenced by patent citations. Quarterly Journal of Economics, 108(3), 577-598.

Kaplan, S.N., Sensoy, B.A., Stromberg, P. (2009). Should investors bet on the jockey or the horse? Evidence from the evolution of firms from early business plans to public companies. The Journal of Finance, 64(1), 75115.

Lee, C., Lee, K., Pennings, J.M. (2001). Internal capabilities, external networks and performance: A study on technology based ventures. Strategic Management Journal, 22(6/7), 615-640.

Marino, K.E., De Noble, A.F. (1997). Growth and early returns in technologybased manufacturing ventures. Journal of High Technology Management Research, 8(2), 225-242.

McDougall, P.P., Covin, J.G., Robinson, R.B., Herron, L. (1994). The effects of industry growth and strategic breadth on new venture performance and strategy content. Strategic Management Journal, 15(7), 537-554.

Mezger, F. (2014). Toward a capability-based conceptualization of business model innovation: Insights from an explorative study. R\&D Management, 44(5), 429-449.

Morris, M., Schindehutte, M., Allen, J. (2005). The entrepreneur's business model: Toward a unified perspective. Journal of Business Research, 58(6), 726-735.

Mullins, J.W. (1996). Early growth decision of entrepreneurs: The influence of competency and prior performance under changing market conditions. Journal of Business Venturing, 11(2), 89-105.

Onetti, A., Zucchella, A., Jones, M. V., McDougall-Covin, P.P. (2012). Internationalization, innovation and entrepreneurship: Business models for new technology-based firms. Journal of Management and Governance, 16(3), 337-368.

Pisano, G.P. (2006). Science business: The promise, the reality, and the future of biotech. Harvard: Harvard Business Press.

Pisano, G.P. (2010). The evolution of science-based business: Innovating how we innovate. Industrial and Corporate Change, 19(2), 465-482.

Porter, M.E. (1998). Clusters and the new economics of competition. Harvard Business Review, 76(6), 77-90.

Raz, O., Gloor, P.A. (2007). Size really matters: New insights for start-ups' survival. Management Science, 53(2), 169-177.

Sandberg, W. R., Hofer, C.W. (1988). Improving new venture performance: The role of strategy, industry structure, and the entrepreneur. Entrepreneurship: Theory and Practice, 2(1), 5-28.

Sapienza, H. J., Grimm, C.M. (1997). Founder characteristics, start-up process, and strategy/structure variables as predictors of short line railroad performance. Entrepreneurship Theory and Practice, 23(1), 5-24.

Siegel, R., Siegel, E., Macmillan, I.C. (1993). Characteristics distinguishing high-growth ventures. Journal of Business Venturing, 8(2), 169-180. 
Smallbone, D., Leigh, R., North, D. (1995). The characteristics and strategies of high growth SMEs. International Journal of Entrepreneurial Behaviour and Research, 1(3), 44-62

Stevenson, H.H., Jarillo, J. C. (1990). A paradigm pf entrepreneurship: Entrepreneurial management. Strategic Management Journal, 11(5), 17-27.

Stuart, R. W., Abetti, P.A. (1986). Field study of start-up ventures-part II: Predicting initial success. Frontiers of Entrepreneurship Research, 21-39.

Song, M., Podoynitsyna, K., Van Der Bij, H., Halman, J.I. (2008). Success factors in new ventures: A meta-analysis. Journal of Product Innovation Management, 25(1), 7-27.

Strauss, A.L., Corbin, J. (2008). Basics of qualitative research: Techniques and procedures for developing grounded theory. Thousand Oaks, CA: Sage.

Teece, D.J. (2007). Explicating dynamic capabilities: the nature and microfoundations of (sustainable) enterprise performance. Strategic Management Journal, 28(13), 1319-1350.

Teece, D.J., Pisano, G., Shuen, A. (1997). Dynamic capabilities and strategic management. Strategic Management Journal, 18(7), 509-533.

Terpstra, D. E., Olson, P.D. (1993). Entrepreneurial start-up and growth: A classification of problems. Entrepreneurship: Theory and Practice, 17(2), 5-20.

Thakor, M.V., Lavack, A.M. (2003). Effect of perceived brand origin associations on consumer perceptions of quality. Journal of Product and Brand Management, 12(6), 394-407.

Vivarelli, M., Audretsch, D.B. (1998). The link between the entry decision and post-entry performance: Evidence from Italy. Industrial and Corporate Change, 7(3), 485-500.

Watson, W., Steward W., Barnir, A. (2003). The effects of human capital, organizational demography, and inter-personal processes on venture partner perceptions of firm profit and growth. Journal of Business Venturing, 18(2), 145-164.

Wirtz, B., Schilke, O., Ullrich, S. (2010). Strategic development of business models: Implications of the Web 2.0 for creating value on the internet. Long Range Planning, 43(2), 272-290.

Yin, R. K. (2009). Case study research: Design and methods. Thousand Oaks, CA: Sage.

Zahra, S.A. (2008). The virtuous cycle of discovery and creation of entrepreneurial opportunities. Strategic Entrepreneurship Journal, 2(3), 243-257.

Zahra, S.A., Bogner, W.C. (2000). Technology strategy and software new ventures' performance: Exploring the moderating effect of the competitive environment. Journal of Business Venturing, 15(2), 135-173.

Zahra, S.A., Matherne, B.P., Carleton, J.M. (2003). Technological resource leveraging and the internationalization of new ventures. Journal of International Entrepreneurship, 1(2), 163-186. 
Zott, C., Amit, R. (2007, March-April). Business model design and the performance of entrepreneurial firms. Organization Science, 18(2), 181-199.

Zott, C., Amit, R. (2008). The fit between product market strategy and business model: Implications for firm performance. Strategic Management Journal, 29(1), 1-26.

Zott, C., Amit R., Massa, L. (2011). The business model: Recent developments and future research. Journal of Management, 37(4), 1019-1042.

Zucker, L., Darby, M., Brewer, M. (1998). Intellectual human capital and the birth of US biotechnology enterprises. American Economic Review, 88(1), 290-305.

\begin{abstract}
Abstrakt (in Polish)
W tym badaniu poszukujemy powiq̨zań między dostosowaniem modelu biznesowego i sukcesem nowych przedsięwzięć. W tym celu, przeprowadzamy dogłębnq analizę ewolucji modelu biznesowego trzech nowych włoskich przedsięwzięć w pierwszym roku ich działalności. Staramy się zrozumieć, czy i w jaki sposób ewolucja modeli biznesowych tych firm przekłada się na ich sukces. Nasza analiza pokazuje, że dostosowanie modeli biznesowych odegrało kluczowg rolę w umożliwieniu tym firmom przetrwanie $w$ ekstremalnie dynamicznych środowiskach. Jednak proces ten nie w pełni zadziałał jako katalizator procesów wzrostu i nie zwiększył rentowności firm.
\end{abstract}

Słowa kluczowe: dostosowanie modelu biznesowego, model biznesowy, nowe przedsięwzięcia, przeżycie, wzrost.

\title{
Biographical notes
}

Bernardo Balboni, Ph.D., is Research Fellow at the University of Trieste. His research interests include business marketing, international business, and SMEs' growth dynamics. On this topics he has published in several international journals, including Industrial Marketing Management, Marketing Intelligence and Planning, The Service Industries Journal, Transformations in Business \& Economics. He has also written some book chapters, and he presented several papers in different international conferences (RENT, EIBA, AIB, EMAC, EURAM). Guido Bortoluzzi, Ph.D., is Assistant Professor of Innovation Management at the Department of Economics, Management, Mathematics and Statistics "Bruno de Finetti" of the University of Trieste (Italy). He has been visiting lecturer in several international institutions worldwide, including University of Northern Colorado (Greeley, U.S.), Lingnan (University) College (Guangzhou, PRC) and ISM University of Economics and Business (Vilnius, LT). His research interests deal with SMEs, strategy and international business. He has published in several international journals, including Harvard Business Review (German edition), International Marketing Review, European Management Journal, European Business Review, Journal for International Business and Enterprise Development, Transformations in Business \& Economics. 